ZENTRUM

FÜR BIODIVERSITÄT UND NACHHALTIGE LANDNUTZUNG

SEKTION

BIODIVERSITÄT, ÖKOLOGIE UND NATURSCHUTZ

-CENTRE OF BIODIVERSITY AND SUSTAINABLE LAND USE- SECTION:

BIODIVERSITY, ECOLOGY AND NATURE CONSERVATION

\title{
RESPONSE OF TREE-RING WIDTH AND REGENERATION IN CONIFER FORESTS OF MONGOLIA TO CLIMATE WARMING AND LAND USE
}

\author{
Dissertation zur Erlangung des Doktorgrades der \\ Mathematisch-Naturwissenschaftlichen Fakultäten der \\ Georg-August-Universität Göttingen
}

vorgelegt von

Khishigjargal Mookhor

Aus der

Mongolei

Göttingen, July 2013 
Referentin/Referent:

Korreferentin/Korreferent:

Tag der mündlichen Prüfung: 15.07.2013
Prof. Dr. Markus Hauck

Prof. Dr. Christoph Leuschner 


\section{Summary}

Mongolia's Larix sibirica forests at the southernmost fringe of the Siberian taiga forest belt border on the semi-arid Eurasian steppe belt. Thus, forest distribution is increasingly fragmented and the woodland consists of a forest-steppe ecotone, which is sensitive to varying environmental conditions. In addition, Mongolia is subject to recent climate warming reflected by a pronounced temperature increase, clearly above the global average, during the last decades which was accompanied by changes in the precipitation regime. Furthermore, land use activities, including logging and livestock grazing in forest, has strongly changed related to the transition from planned to market economy since 1990.

This thesis presents research results from isolated larch forest islands at high altitude (ca. $2300 \mathrm{~m}$ a.s.l.) in the Altai Mountain, which are used for mobile livestock husbandry. In addition, investigations from the central Mongolian forest-steppe ecotone (Mt. Bogd Uul) are included. Mt Bogd Uul is an officially protected area since the $13^{\text {th }}$ century. We were especially interested in the questions how climate warming and land use by the local herder populations influence the annual stem growth, stand structure, forest regeneration and the wood anatomy.

Our study from Mt. Bogd Uul in the Mongolian forest-steppe ecotone shows that increased summer droughts are the key factor in reducing radial stem growth of L. sibirica in the past decades. Tree-ring width increases with increasing June precipitation of the current year (June) and increasing late summer precipitation of the previous year. In >100-year old trees, also a negative correlation of tree-ring width with the July temperature of the year prior to tree-ring formation was found. The most significant change in wood anatomy was the decline of wide latewood, which is attributable to the increase of summer days with a mean temperature $>15^{\circ} \mathrm{C}$ and drought periods in summer without any precipitation. Increasing summer droughts are also thought to have caused the repeated occurrence of missing rings since the $1960 \mathrm{~s}$, which were not observed in the late $19^{\text {th }}$ and early $20^{\text {th }}$ century.

The results from Altai Mountains show that trees benefit from the increased temperatures. Climate-response analysis revealed that radial stem increment was promoted by the temperature in early summer, but also high precipitation in spring in the year before tree-ring formation. Forest dynamics is also strongly influenced by human activities. In addition to the natural forest 
dynamics, logging resulted in divergent growth trends within given age classes and habitats (forest interior and forest edge); overall, 22 groups of trees with different characteristics in the annual radial stem increment were identified. A tree-ring series-based reconstruction of logging intensity since 1935 suggests that moderate selective logging occurred throughout the study period. However, selective logging was strongly intensified after 1990. Because tree stump densities showed that the ratio of felled to live trees was 2:1 in the interior or 0.9:1 at the edges of the forests and most logging occurred during the past 20 years, it must be concluded that the forests of the Mongolian Altai are presently exploited far beyond the level of sustainability. A close correlation of the ratio of felled to live trees with the density of summer camps of pastoral nomads in the vicinity suggests that trees are primarily felled by the local population.

Past regeneration was reconstructed from tree rings and present regeneration was analyzed by surveying seedlings, saplings and the occurrence of viable larch seeds in the soil seed bank. Forest regeneration occurred throughout the $20^{\text {th }}$ and the early 21 st centuries in the forest interiors, but ceased after the late 1970s at forest edges. The density of larch saplings decreased with livestock density following a linear slope in the interior and an exponential decline at the edge. Most saplings had visible damage from livestock browsing, which was also manifested in woodanatomical anomalies. Near-consistency of the correlations of total livestock and goat densities with sapling and seedling densities suggests that the control of larch regeneration is primarily hampered by goats. In contrast to saplings, larch seedlings were positively correlated with livestock density, indicating that grazing apparently promote seedling emergence by reducing competition from the ground vegetation.

Overall, the present investigations of the response of larch forest to changes in climate, unplanned logging and livestock grazing provides new insights for the discussion of potential future responses to climate warming climate and land use intensification in Mongolia's foreststeppe. We assume that, in the near future, the retreat of larch forests from the the lower tree lines to the steppe is likely at many places, partly because of increased aridity, but at places with favorable climate for tree growth and regeneration due to recent increases in the population of cashmere goats. 


\section{LIST OF ABBREVIATIONS}

\begin{tabular}{|c|c|}
\hline ANCOVA & One way analysis of covariance \\
\hline ANOSIM & One way analysis of similarities \\
\hline ANOVA & Two way analysis of variance \\
\hline a.s.l. & Above sea level \\
\hline $\mathrm{cm}$ & Centimeter \\
\hline $\mathrm{DBH}$ & Diameter breast height \\
\hline EPS & Expressed population signal \\
\hline FAO & Food and Agriculture Organization \\
\hline $\mathrm{FE}$ & Forest edge \\
\hline FI & Forest interior \\
\hline ha & Hectare \\
\hline h & Hour \\
\hline IPPC & Intergovernmental Panel on Climate Change \\
\hline IAWAF & Intra-annual wood anatomy features \\
\hline IUFRO & International Union of Forest Research Organizations \\
\hline $\mathrm{m}$ & Meter \\
\hline $\mathrm{mm}$ & Millimeter \\
\hline $\mathrm{Mt}$ & Mountain \\
\hline MET & Ministry of environment and tourism \\
\hline NMDS & Non-metric multidimensional scaling \\
\hline PPFD & Photosynthetic photon flux density \\
\hline RGC & Regional growth curves \\
\hline TSAP & Time Series Analysis and Presentation \\
\hline S & South \\
\hline $\mathrm{yr}$ & Year \\
\hline
\end{tabular}




\section{TABLE OF CONTENTS}

\section{CHAPTER 1}

General Introduction

1.1 Influences of global warming, climate change and human activities on coniferous forests....................................................................... 10

1.2 Climate and forests in Mongolia .................................................. 11

1.2.1 Intra annual tree-ring anomalies..............................................

1.2.2 Tree radial and annual growth changes in Mongolia.........................15

1.2.3 Forest natural regeneration..............................................

1.3 Methodology- Research design ............................................... 17

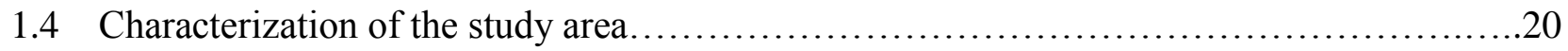

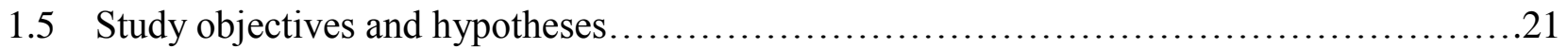

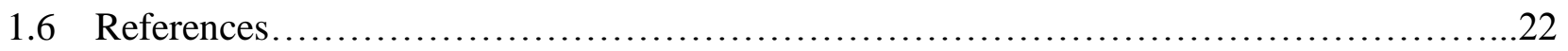

\section{CHAPTER 2}

Climate effects on inter- and intra-annual larch stemwood anomalies in the Mongolian foreststeppe

Abstract......................................................................29

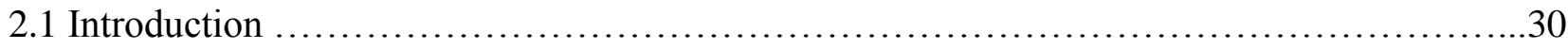

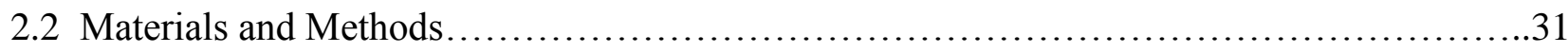

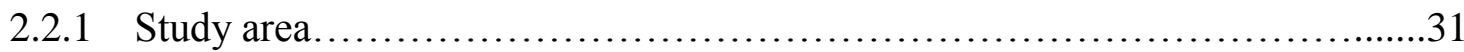

2.2.2 Wood core sampling and laboratory work for tree-ring analysis...............32

2.2.3 Study of wood-anatomical features...................................... 34

2.2.4 Climate data and climate-response analysis.............................

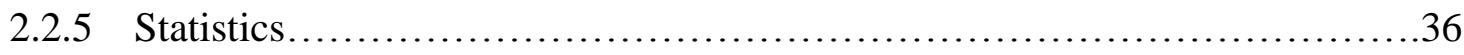

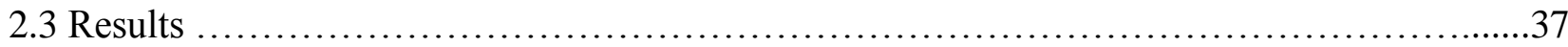

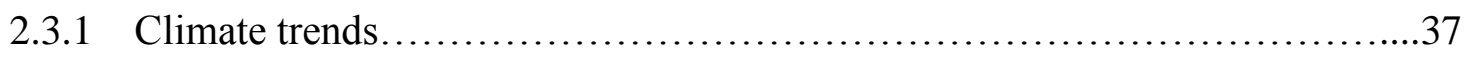

2.3.2 Tree-ring chronologies and climate response of tree-ring width................38

2.3.3 Wood-anatomical features........................................40

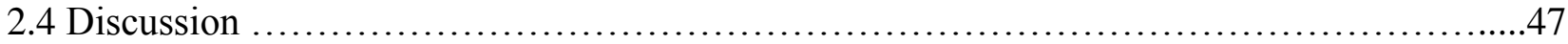

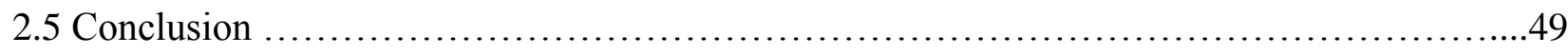

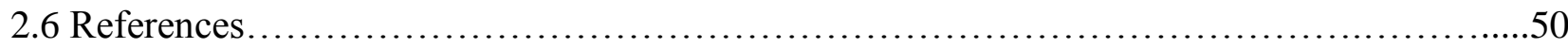

\section{CHAPTER 3}

Response of tree-ring width to climate warming and selective logging in larch forests of the Mongolian Altai

Abstract. 


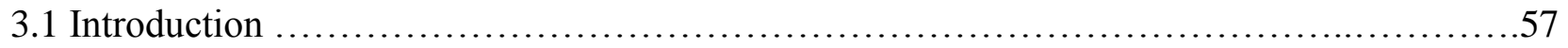

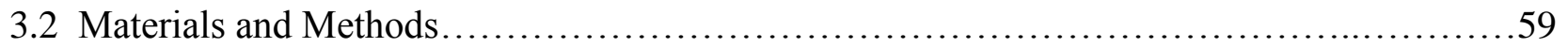

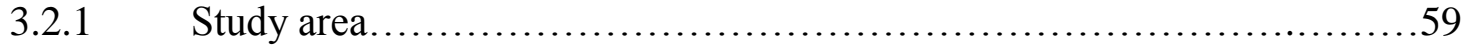

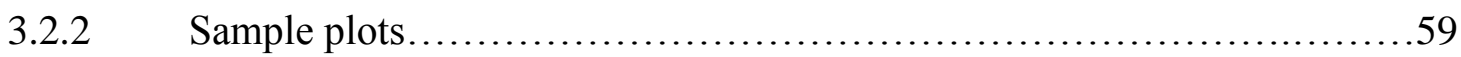

3.2.3 Analysis of climate trends from weather data...........................60

3.2.4 Field and laboratory work for tree-ring analysis..........................61

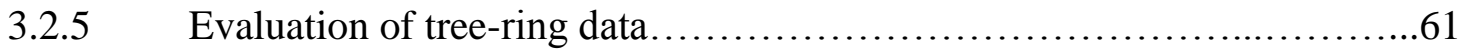

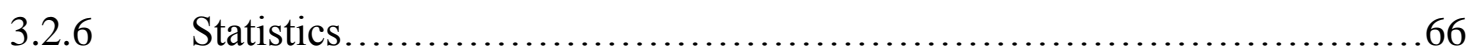

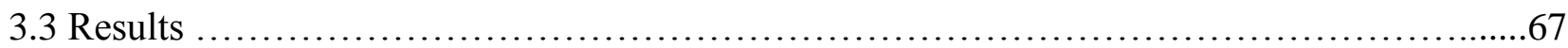

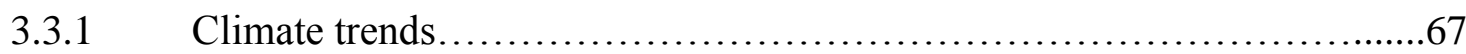

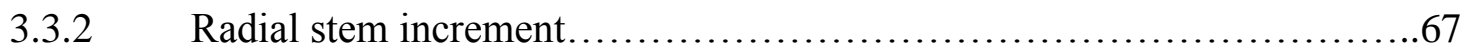

3.3.3 Mean sensitivity and first-order autocorrelation...........................69

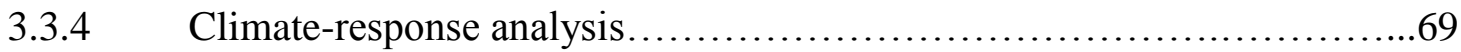

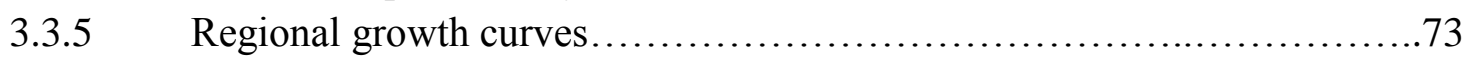

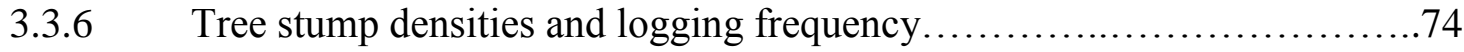

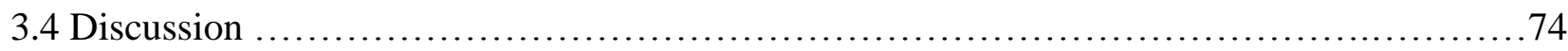

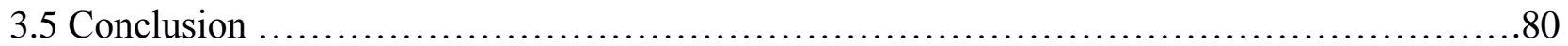

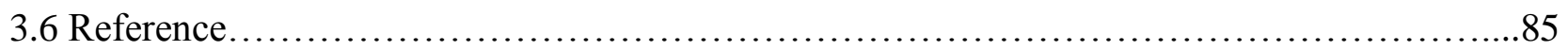

\section{CHAPTER 4}

Contrasting responses of seedling and sapling densities to livestock density in the Mongolian forest-steppe

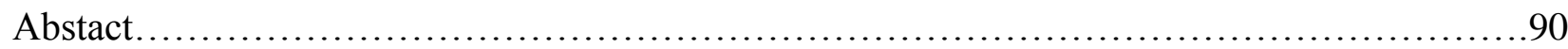

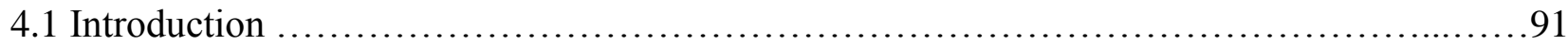

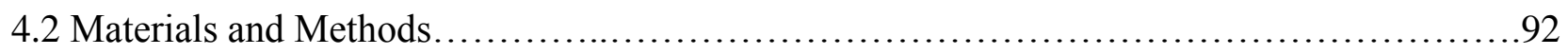

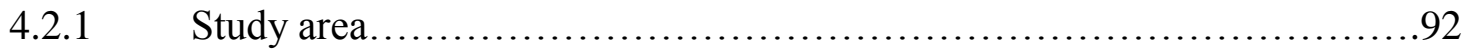

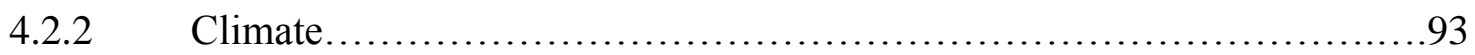

4.2.3 Sample plot design ............................................... 94

4.2.4 Reconstructing past tree establishment from tree rings ...................94

4.2.5 Survey of sapling numbers, age and grazing damage ...................96

4.2.6 Assessing seedling numbers and survival ..............................96

4.2.7 Analyzing relationships of sapling and seedling density and vitality with livestock densities......................................................97

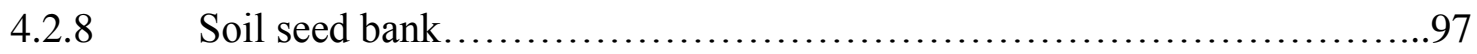

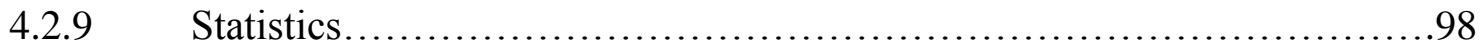

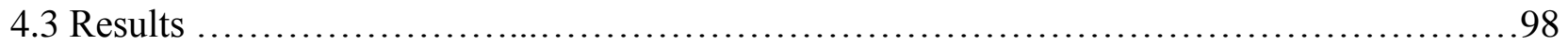

4.3.1 Tree establishment between 1900 and 2010.........................98 
4.3.2 Correlations between browsing damage in saplings and livestock density......................................................104

4.3.3 Recent seedling emergence and correlations with livestock density........106

S.3.4 Soil seed bank............................................... 107

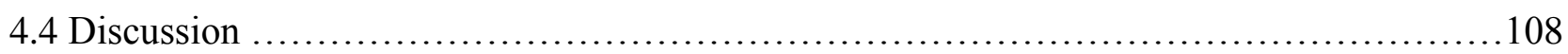

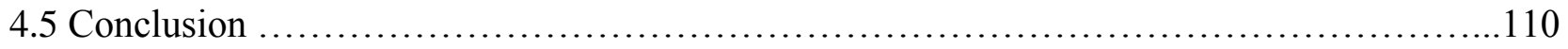

4.6 Reference..................................................................... 112

\section{CHAPTER 5}

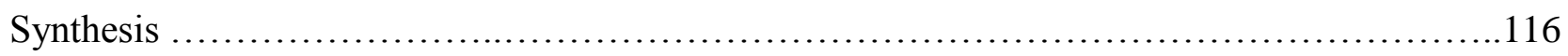

5.1 Climate responses of tree-ring width and wood anomalies in larch forest...................116

5.2 Influences of logging and livestock grazing on larch forest regeneration....................117

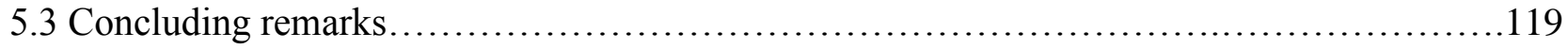

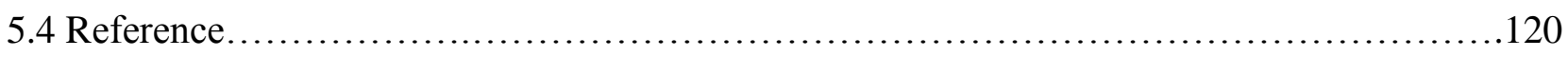

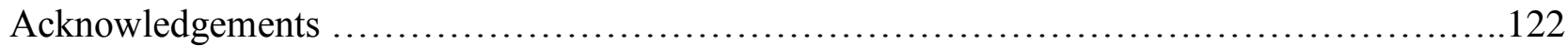

Curriculum Vitae ................................................................... 123

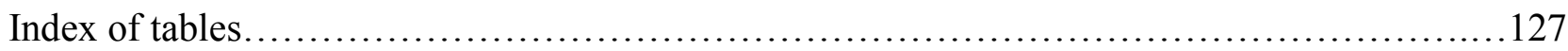

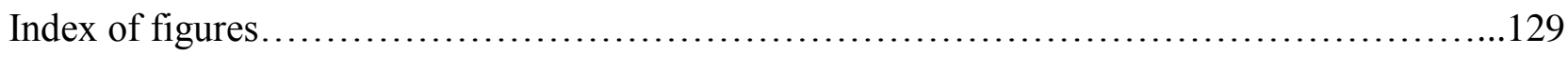




\section{CHAPTER \\ 1}

\section{GENERAL INTRODUCTION}




\subsection{Influences of global warming, climate change and human activities on coniferous forests}

Coniferous forests are of particular interest and are dominating high-latitude forest ecosystems. They cover approximately $3.6 \times 10^{9}$ ha, or $24 \%$ of the terrestrial surface of the globe. Conifers include approximately 625-700 species worldwide and they are important to the world's landscape and ecology. In addition, about a third of all species (186 species) are threatened or vulnerable throughout their geographic ranges. More than $60 \%$ of conifer species and $90 \%$ of the genera may be found between $500 \mathrm{~m}$ and $1.500 \mathrm{~m}$ elevation (Eckenwalder, 2009). A significant shift in the distribution and extent of coniferous forests may release large amounts of carbon into the atmosphere due to climate change (Goodale et al., 2002; Kimmins, 2004).

Nowadays, the concern about global warming and its impact on ecosystems is a central issue in science and policy decision making. The temperature increase has been reached up to $0.64^{\circ} \mathrm{C}$ between 1950 and 2000 (IPPC, 2001, 2007). Warming trends are thighest in the northern boreal latitudes, about $1-2^{\circ} \mathrm{C}$, since 1970 (Boisvenue \& Running, 2006). In 2007, Saeger et al. reported that future climate change is likely to further increase by $2-4^{\circ} \mathrm{C}$ globally with significant reductions in annual precipitation in certain regions, as well as an increase in the frequency of droughts and heat waves under conservative predictive scenarios.

The climate change has various positive and negative effects on forests at local and global levels. The more obvious effects are through a change in phenology (growing season lengthening), tree growth rates (forest growth trends reduction or increase), and the frequency and extent of disturbances (wildfire, epidemics of pathogens and windstorms).

The most obvious dynamic of forest biogeographical boundaries with current warming trends is an upward shift in the timberline and northward migration of boreal forests (Warning \& Running, 2007). On average, wherever conifers grow, they favor cooler sites than nearby flowering plants so that warming trends may tip the balance toward angiosperms, however low nutrient status of soils and a landscape-level fire regimen are other environmental factors favorable to conifers (Eckenwalder, 2009). Research results based on global overall climate change have shown recent tree mortality incidents attributed to drought and heat stress (Allen et al., 2010). For example: Russian Federal Forest Agency show that the climate effects in coniferous forests in Russia can be divided as $3.38 \times 10^{6}$ ha "low threat", $2.6 \times 10^{6}$ ha "medium" threat, and $0.76 \times 10^{6}$ ha "high threat" predominantly in southern parts of the country with mapped zones of forest health risk 
("threat") (Kobelkov, 2008). The same situation has been seen in northern American coniferous forests, where background mortality rates have increased in recent decades (Guarin \& Taylor, 2005). Furthermore, recent tree ring studies in northern forests have described generally positive response to warming (Jacoby et al., 1996; Hasenauer et al., 1999; Joos et al., 2002). At the same time, some research show contrasting patterns with a reduction of forest growth (D.Arrigo et al., 2008; Dulamsuren et al., 2010 b, 2011)

Forests always have been important resources for humans, but have been extremely affected by land-use change Foley at al. (2005) estimate $7 \times 10^{6}$ to $11 \times 10^{6}$ sq. $\mathrm{km}$ of forested area land have been converted mostly to agriculture in the last 300 years. Especially temperate coniferous forests have been cleared for farming and building communities which led to the decline and loss of these forests in many parts of the world.

\subsection{Climate and forests in Mongolia.}

Mongolia is situated in the east and central part of Asia $\left(45^{\circ} 00 \mathrm{~N} ; 105^{\circ} 00 \mathrm{E}\right)$. It has a total area of 1.565.000 sq.km and is one of the largest landlocked countries in the world. The topography of Mongolia consists mainly of a plateau with the elevation ranging from $914 \mathrm{~m}$ to $1.524 \mathrm{~m}$, broken by mountain ranges in the north and west. Its fragile ecosystems, pastoral animal husbandry and rain-fed agriculture are extremely sensitive to climate change (Tsegmid, 1969; National Atlas., 1990). The climate change poses great challenges to Mongolia which is one of the most vulnerable countries in the world to adverse impacts of climate change due to its geographical location, weather and climate conditions as well as specific features of socio-economic development.

In the last 70 years, the annual mean temperature of Mongolia increased by $2.17^{\circ} \mathrm{C}$ according to the records of 48 meteorological stations distributed across the country. This is significantly above the global average and it is projected to increase up to $5^{\circ} \mathrm{C}$ by the end of the $21^{\text {st }}$ century. Since 1940, the average winter temperature has been noticeably increasing as compared to summer temperature (Batima et al., 2005). Clearly, the number and duration of hot days were dramatically increased during the last decades (Batima et al., 2005; Nandintsetseg et al., 2007). There were no significant changes in the precipitation amount during last 70 years. However, winter precipitation increased, whereas warm season precipitation change is increased by number of thunderstorms 
during the growing season. Instead of long lasting rains, short heavy rains on small areas are becoming more frequent (Sarantuya \& Natsagdorj, 2010).

It is widely agreed that a reduced precipitation trend has been observed over land areas in the Northern Hemisphere, especially over northern Eurasia, including Mongolia since the mid-1950s (Dai et al., 2004).

Studies show that in the last 40 year's climate change has caused great damage not only to the livestock sector but also to the ecology and socio-economic sectors in Mongolia (Campi, 2011; Lhagvadorj et al., 2013). In the coming century, climate change will radically affect the traditional way of living which was established in Mongolia for more than thousands of years (Sarantuya \& Natsagdorj, 2010).

Mongolia, long known for its vast steppe and nomadic culture, is also one of democracy's most recent converts. The post-soviet transition has slowly fed a growing economy based upon development and extractive industry. In association with its high latitude and continental location merging steppe, desert and forest ecosystems, Mongolia is also expected to bear an inequitable share of global climate-change-related impacts (MacDonald et al., 2008; Jones et al., 2009).

The area classified as forest (including certain non-forested areas) is estimated at $17.8 \times 10^{6}$ ha (11.4\% of the land area), the area of closed forest at $12.8 \times 10^{6}$ ha. The most prevalent forest tree species is Siberian larch (Larix sibirica), consisting of $80 \%$ of total forested area (Tsogtbaatar, 2004; Gunin et al., 1999). Siberian Larch distributed in widespread taiga zone of north-central Eurasia from northwestern Russia across western Siberia to the Yenisei River in the north-and near Lake Baikal in the south, with outliers in mountains of Mongolia and northwestern China. Forming pure, open stands or mixed with other boreal conifers and hardwoods on great variety of sites and substrates but reaching its best development on warm, sandy sites, generally at higher elevations southward from 0-2400 m a.s.1. (Eckenwalder, 2009).

Larch forests occupy a leading position among other forests of Mongolia and they display important resources and ecological functions. The forests are the southern-most fringe of the Siberian taiga and bordered with grassland steppe creating numerous forest-grassland ecotones (Dugarjav, 2006). The growth rate of Mongolian forests is slow due to the harsh continental climate in Mongolia, which is much harsher than in other countries within a similar latitudinal zone and characterized by extremes in both temperature and its fluctuations (MET, 2009-2010). Preciptation, concentrated during the summer period, is low with annual average about $300 \mathrm{~mm}$ in 
northern forest zones. As a result of the harsh climate, these northern forests are easily influenced by fire, insects and human activities (Dugarjav, 2006). Also the borderline of forest and steppe has been modified by human activities and the lack of conifers which is due to drought (Gunin et al., 1999; Dulamsuren et al., 2010b, 2011)

Forests in Mongolia have been severely degraded by forest fire, illegal logging and inadequate management. During the last decades, Mongolia has lost approximately $4 \times 10^{6}$ ha of forests averging 40.000 ha annually. Between 1990 and 2000, the rate of deforestation increased to 60.000 ha per year. As a result, this ongoing loss and degradation has been negatively affected also the environment of neighboring countries such as Korea, (Tsogtbaatar, 2004; Park et al., 2007). Moreover, 383.6000 hectare forested area of Mongolia disappeared due to fire, illegal logging and pest insects' invasion from 2008 to 2010 (MET, 2009-2010; Ykhanbai, 2010). Nomadic herding with free-roaming animals is a major factor influencing forest regeneration in the central Asian forest-steppe ecotone (Treter, 2000; Sankey et al., 2006). Grazing pressure is high on grassland area, and it has been increased since 1990. Moreover, forests are strongly affected by increasing grazing pressures (Hauck et al., 2011; Lkhagvadorj et al., 2013). Herders reported less desirable grazing areas which are used during drought or other disasters precludes grazing in grasslands (Ykhanbai, 2010).

Other uses of the forest include firewood, materials for fencing, timber, berries, pine nuts, and wide variety of food and medicinal plants. Some materials are used locally, while others are transported to urban centers, notably Ulaanbaatar. Export of plant materials, fungi and animal parts for traditional Chinese medicine is concerned as a serious problem in Mongolia resulting in forest degradation (Adyasuren, 1998; Davgadorj et al., 2009). Pressure on these resources has increased since the end of the Soviet era (Erdenechuluun, 2006; MET, 2009-2010; Lkhagvadorj et al., 2013). Ykhanbai, (2010) there increased unsustainable harvesting of some non-timber forest products, were described.

\subsubsection{Intra-annual tree-ring anomalies}

In conifers, a tree ring is composed of two (more or less distinct) bands of cells. The earlywood, it is a light-coloured band and laid down in the spring and early summer.. The xylem cells produced 
by the cambium are then rather large in diameter and have noticeably thin walls $(1.5-3 \mu \mathrm{m})$. Latewood is produced later on in the summer and in the early fall. Latewood cells are somewhat smaller than the early wood cells and have a much thicker cell wall (which can reach up to 7-8 $\mu \mathrm{m})$ and much smaller lumen, accounting for the darker colour of the latewood. At the end of the growing season, wood production shuts down until the following spring, when large, thin-walled cells are again produced by the cambium, making a very sharp contrast with the previous year's dark, tight latewood in conifer trees (Schweingruber, 1988; Vagonov et al., 2011). In conifer and deciduous trees, intra annual and inter annual anatomic heterogeneity are mainly based on the variability of shape of the fiber tissue elements and cell wall thickness.

Short term extreme events that occur during the growth periods cause anomalies within tree rings or growth zones (intra-annual variability) such as collapsed cells, reaction wood and increased resin ducts. Seasonal climate changes, such as cold or dry periods in connection with a variable diurnal cycle, are often expressed as tree rings (inter-annual variability), whereas changing site conditions give rise to periodical structural changes of several years duration (Schweingruber, 2007). Therefore, tree rings contain an image of the time when the ring was formed, projected onto the ring's size, structure, and composition as well as climatic events of the particular year. Tree rings thus are natural archives of past environments and contain records of the past climate (Carlquist, 2001; Shweingruber, 2007; Wimmer et al., 2002).

Generally, most tree rings of conifer trees look more or less the same and some rings known as marker rings (or pointer years) may be conspicuously different from their neighbours. Such rings are useful for cross-dating; some of them even represent localized or widespread disturbance events such as frost, insect epidemics, and droughts. Tree-ring anomalies are often reflective of short term events such as early summer drought that may not be recorded in ring width data and thus it could provide for reconstructing climatic events occurring prior to the advent of meteorological records (Wimmer et al., 2002; Tardif et al., 2011).

Narrow rings are the most useful of all marker rings. A series of narrow rings may indicate a few years of unfavourable growing seasons (Meko et al., 2001; Schweingruber, 2007). It may also indicate an insect outbreak causing intense defoliation and therefore little growth; if that is the case, the series of narrow rings will only be present in the species that are affected by the defoliator, and other species will not show that insect signature (Schweingruber, 1988). 
Only few studies focused on the effect of climate on intra-annual wood anatomical features in Mongolia. These former studies represent frequency and cause of frost rings by D'Arrigo et al. (2001) and false and light rings by De Grandpré et al. (2011) in the forest-steppe ecotone. In our study, eleven different intra-annual and inter-annual wood anatomical features (IAWAF) were analyzed on core samples which were collected from Mt. Bogd Uul. In addition, four different IAWAF, were analyzed on small cross-sections from Altai Mountains. Our wood anatomy studies mainly focused on the frequency of narrow rings, wedging and missing rings (Fig. 1.1) under significant climate change and intensive grazing pressure throughout recent decades.

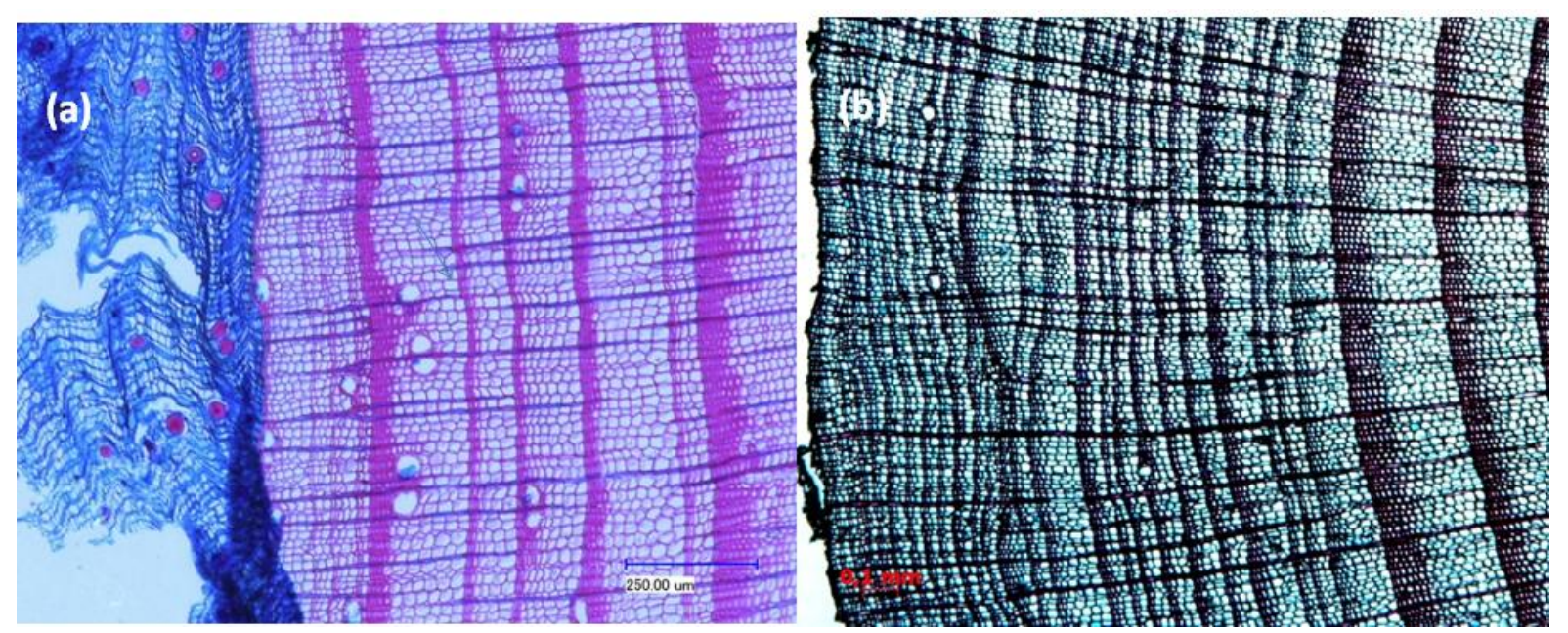

Fig. 1.1. (a) Rings with extremely narrow late wood in previous years on core samples from Mt. Bogd. (b) Narrow and wedging rings on the cross-section samples from Altai Mountains during last decades. (Photos: M.Khishigjargal)

\subsubsection{Tree radial and annual growth changes in Mongolia}

The growth of a tree ring is the result of periclinal divisions of cells and their differentiation in the cambial zone. The growth rate depends on the number of cells in the cambial zone and their rate of division. In coniferous species, the growth of tree rings during growing season is always accompanied by a change in the number of cambial cells, which has characteristic dynamics that are general for all species (Antonova \& Stasova, 1997; Schweingruber, 2007). Tree-ring analysis or dendrochronology, is defined as the study of the pattern in sequence of annual growth rings in trees through time. Over the past decades, dendroecological techniques have become an important tool in the studies of stand dynamics and ecological history (Fritts, 1976), such as species recruitment 
patterns, periodicity and intensity of disturbances, and influences of climatic variation and extreme weather events (Oberhuber, 2004; Dang et al., 2008)

Mongolian forests have been popular study objects for climate reconstructions. Several dendrochronological studies have been carried out in Mongolia within the Mongolian-American Tree-Ring Project (Matrip) led by G.Jacoby since 1995. These studies mainly focused on regional climate reconstruction which reveal the effect of global climate change on Mongolia using relatively few samples (Jacoby et al., 1999; D’Arrigo et al., 2001; Pederson et al., 2001). The main results can be summarised as evidence of climate changes occuring in Mongolia, whereby the increasing temperature trends are in agreement with the hemispheric trend towards warming in the 20th century. For example, increased annual increment of Pinus sibirica were revealed at an Alpine forest line (Jacoby et al., 1999) and precipitation and streamflow were reconstructed more than 300 years by D'Arrigo et al. (2000). Recently, assumptions regarding the consistency of treetemperature sensitivities have been challenged by findings that have detailed diverging signals (Wilmking et al., 2004; D’Arrigo et al., 2008) and indirect relationships. Whereas most published literature documents showed a positive correlation between temperature and radial growth at northern latitudes (Jacoby et al., 1999; D’Arrigo et al., 2001). Some other studies analyze relationships of climate with the annual stem increment to detect global warming responses of the forest ecosystems which partly also include the study of trends in forest regeneration (Jacoby et al., 1996; Dulamsuren et al., 2010a, b; De Grandpré et al., 2011). Both the stimulation and inhibition of annual stem increment have been reported along with rapidly changing climate in Mongolia.

Changes including reduced stem growth and regeneration have been observed in Mongolian larch forests (Dulamsuren et al., 2010b, 2011), where these parameters either remained constant or even increased from region to region.

\subsubsection{Forest natural regeneration}

Forest natural regeneration is defined as 'the renewal of a forest crop by self-sown seed or by coppice of root suckers, which is the act of renewing tree cover by establishing young trees naturally', promptly the previous stand, responses to climate warming with various land use effects. 
Forest growth and natural regeneration are differing significantly within regional climate variations; especially forest regeneration was shown to be strongly hampered by increased aridity (Dulamsuren et al., 2009, 2010a, b) including ecology and economy conditions in northern Mongolia. The increased drought during the growing season due to the simultaneous increase in summer temperature and decrease in precipitation has the greatest detrimental effect on Larch forests, whereas the growth is significantly reduced and the reproduction fails to occur. These effects have been observed in the north western Khentii province. In contrast, increased annual precipitation at constant summer temperature has been observed in south eastern Khentii province and resulted in constant or even improved growth and regeneration. The increased temperature during the growing season at constant precipitation led to reduced growth and regeneration in south western Khentii province and the Eastern Khangai Mountains.

Livestock breeding is a major factor that influencing forest regeneration in the central Asian foreststeppe ecotone (Sankey et al., 2006). The livestock primarily grazes on grasslands, but it does significantly affect tree regeneration at forest lines and even penetrates into the forest interior (Fig. 1.2). The research area in Altai Mountains are subject to intensified livestock grazing and timber cutting (Lhagvadorj et al., 2013).
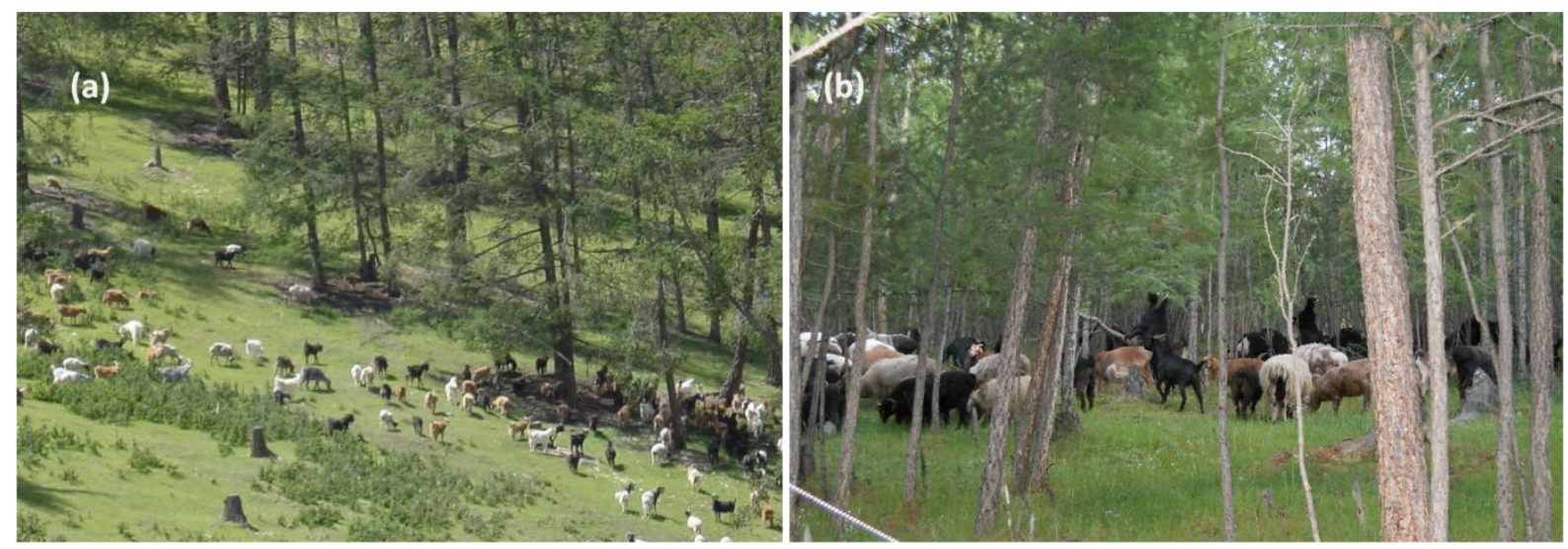

Fig. 1.2. Livestock, including sheep and goat herd, grazing in larch forest (a) and forest edge (b) of forest interior (Photos: M.Khishigjargal)

\subsection{Methodology- Research design}

The main research site was located at the Altai Mountains (48 $\left.27^{\prime} \mathrm{N}, 88^{\circ} 90^{\prime} \mathrm{E}\right)$ in north western Mongolia, where the forested area is remarkably isolated from surrounding conifer forests (Fig. 
1.3). The second research site was located in Mt. Bogd Uul, which was one of the previous research sites studied by Dulamsuren et al. 2010a in northern Mongolia (Fig. 1.3).

Climate warming was more pronounced in the high mountains $\left(1.9^{\circ} \mathrm{C}-2.28^{\circ} \mathrm{C}\right)$ and less in the Gobi desert $\left(1.6^{\circ} \mathrm{C}-1.7^{\circ} \mathrm{C}\right)$ in Mongolia (Sarantuya \& Natsagdorj, 2010). Climate trends were analyzed from the nearest metrological stations in both research areas, in which annual mean temperatures have significantly increased but annual precipitation remained constant during past decades. The available climate data covered a time period of 70 years.

Three sample plots $(20 \mathrm{~m} \times 20 \mathrm{~m})$ were established in the forest interior, 50-100 $\mathrm{m}$ inside from the forest lines avoiding edge effects. Another plot was established at the forest edge, which was at the border between the steppe grassland and forest lower line (Fig. 1.4). The main plots in the forest interior and at the forest edge included five sub plots $(1 \mathrm{~m} \times 1 \mathrm{~m})$ for seedling counting and for taking seed samples from soil organic layer (Fig. 1.4).

Totally, 1826 tree wood-core samples and 521 cross section samples were used for tree ring analysis from Altai Mountains based on applied methods or techniques by Dulamsuren et al. (2010 a,b,c) using TSAP (Time Series Analysis and Presentation)-Win software (Rinntech, Heidelberg, Germany). Annual tree-ring width was measured with a precision of $10 \mu \mathrm{m}$ on amovable object table (Lintab 5). Crossdating was measured based on the use of two parameters: coefficient of agreement ('Gleichläufigkeit' [GL]) (Eckstein \& Bauch, 1969) and standard $t$-values and also detect the years when no tree ring was formed (Fritts, 1976; Schweingruber, 1988).

The temporal development of the establishment of larch trees was analyzed in all 24 plots in Altai Mountains. The years of establishment (i.e., germination) of the individual tree was inferred from the wood-cores taken at $1.3 \mathrm{~m}$ above the ground by adding 10 years to the oldest tree ring. Samples including tree cores (174) from Mt. Bogd Uul (4746’ N, $107^{\circ} 07^{\prime}$ E.) (Fig.3) and small cross sections from Altai Mountains for wood anatomy analysis were prepared using microtome preparations. Microtome sections and other special prepared surfaces of small cross sections were scanned with the microscope tree-ring wise. Images for detailed wood anatomy counting and analysis were done with Stereo Discovery V20 dissecting microscope (Carl Zeiss, Jena, Germany). 


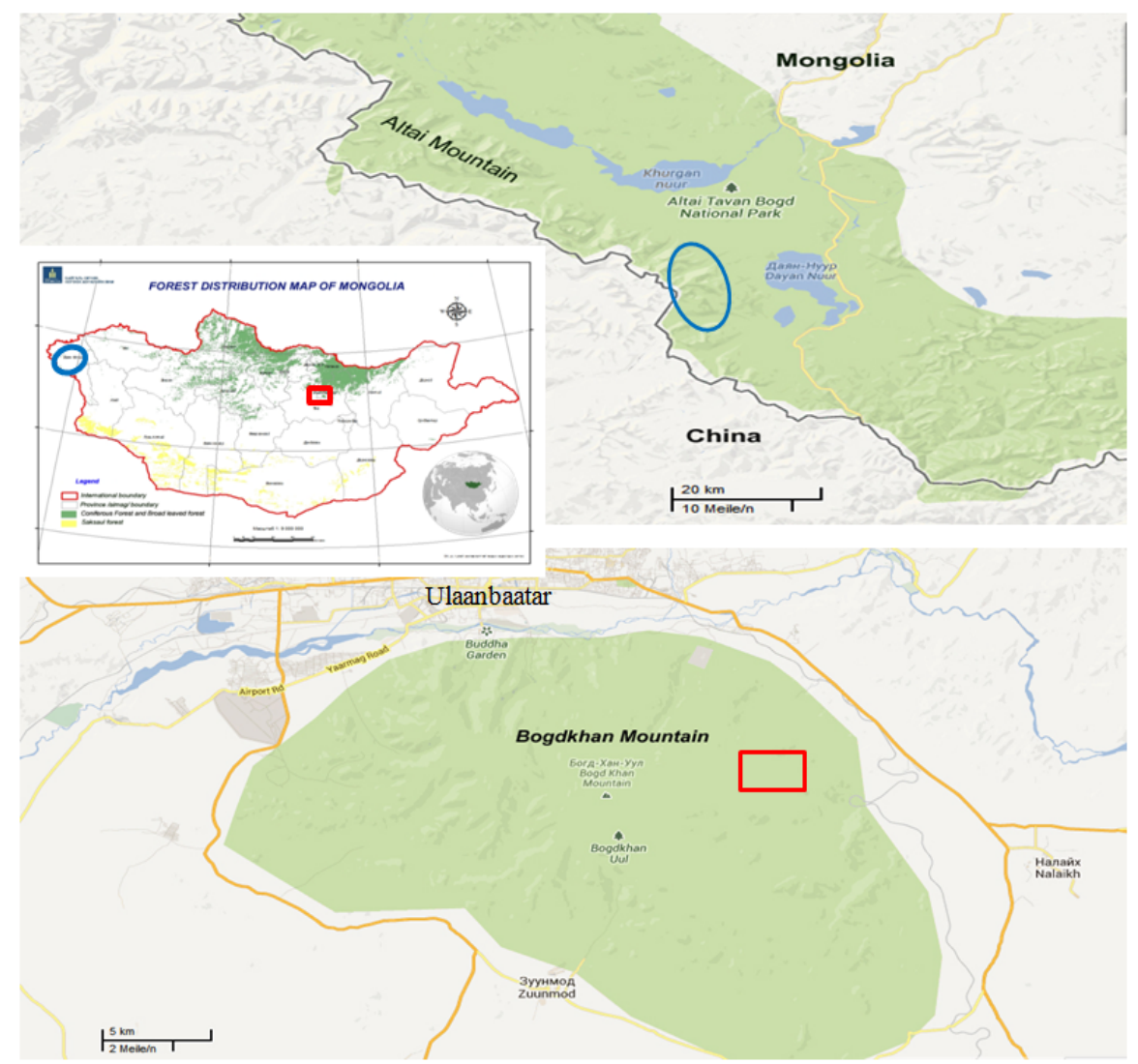

Fig. 1.3. Location of the study region in northern Mongolia. (blue) Altai Mountains research area. (red) Bogd Mountain research area (Map sources: http://maps. Google.de; http: //www.Globaltrade.net.map Mongolia.html \& Forest distribution map of Mongolia; Ministry of Environment and Green development)

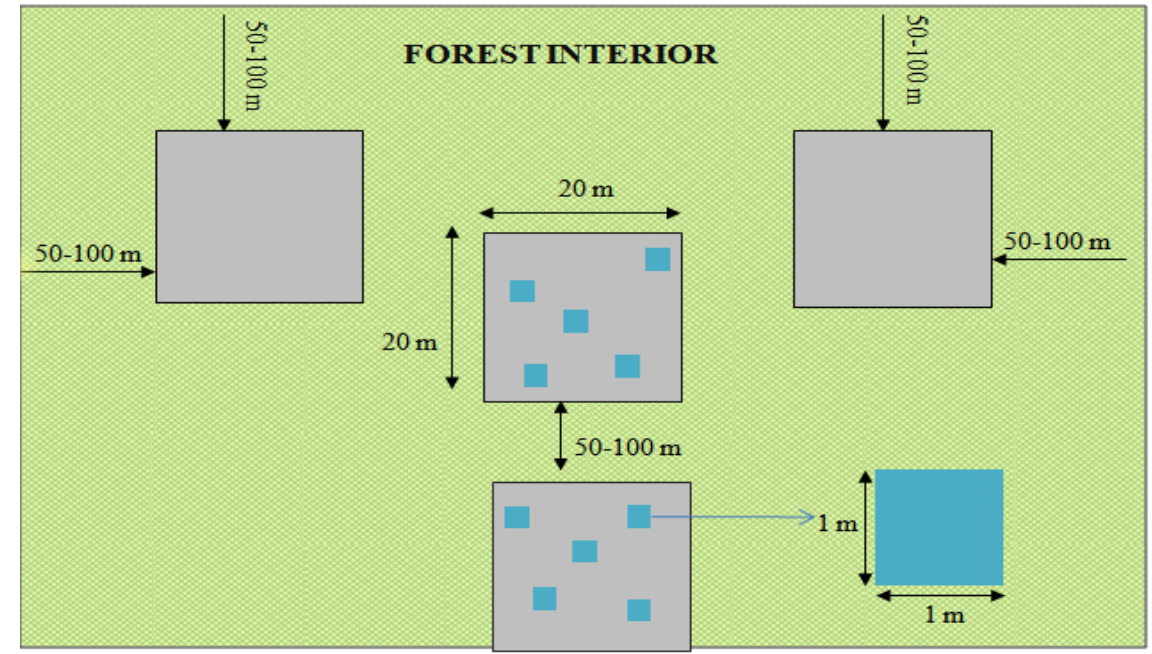

FOREST EDGE

Fig. 1.4. Schematic overview of the plot design. Three research plots in forest interior and one plot in forest edge. Sample plots (20m x 20m) (gray) and sub plots (1m x 1m) (blue) for seedling counting. 


\subsection{Characterization of the study area}

Siberian larch (Larix sibirica L.) is a deciduous conifer tree species, which is strongly dominating the forests in northern Mongolia and of high ecological as well as economic value. The timber line is about $1800 \mathrm{~m}$ a.s.l at the Mt. Bogd Uul and about $2000 \mathrm{~m}$ a.s.l at the Altai Mountains. Forests usually occur in relatively small patches (Fig. 1.5) in Altai Mountains, which is a high elevation landscape. Mt. Bogd Uul is the most southern part of the Khentii Mountains, which are surrounded by the Mongolian-Daurian steppe in the west and south and by the Eastern Mongolian steppe in the east (Dulamsuren et al., 2005).

Local socio-economy conditions are different in the studying areas. Nomads first moved to the Altai Mountains 2000-3000 years ago (Ruday et al., 2008). Livestock numbers have dramatically increased during recent decades after the Communist system was replaced by a parliamentary democracy in 1990 and the economy was transformed into market economy (Lhagvadorj et al., 2013). As a result, the research area is subject to intensive human activities. By contrast, Mt. Bogd Uul is protected from grazing and other human activities. This region is one of oldest officially protected areas as it was declared a National Park in the $13^{\text {th }}$ century and now also part of the UNESCO world heritage list (UNESCO world heritage List., 1996; De Grande et al., 2011).
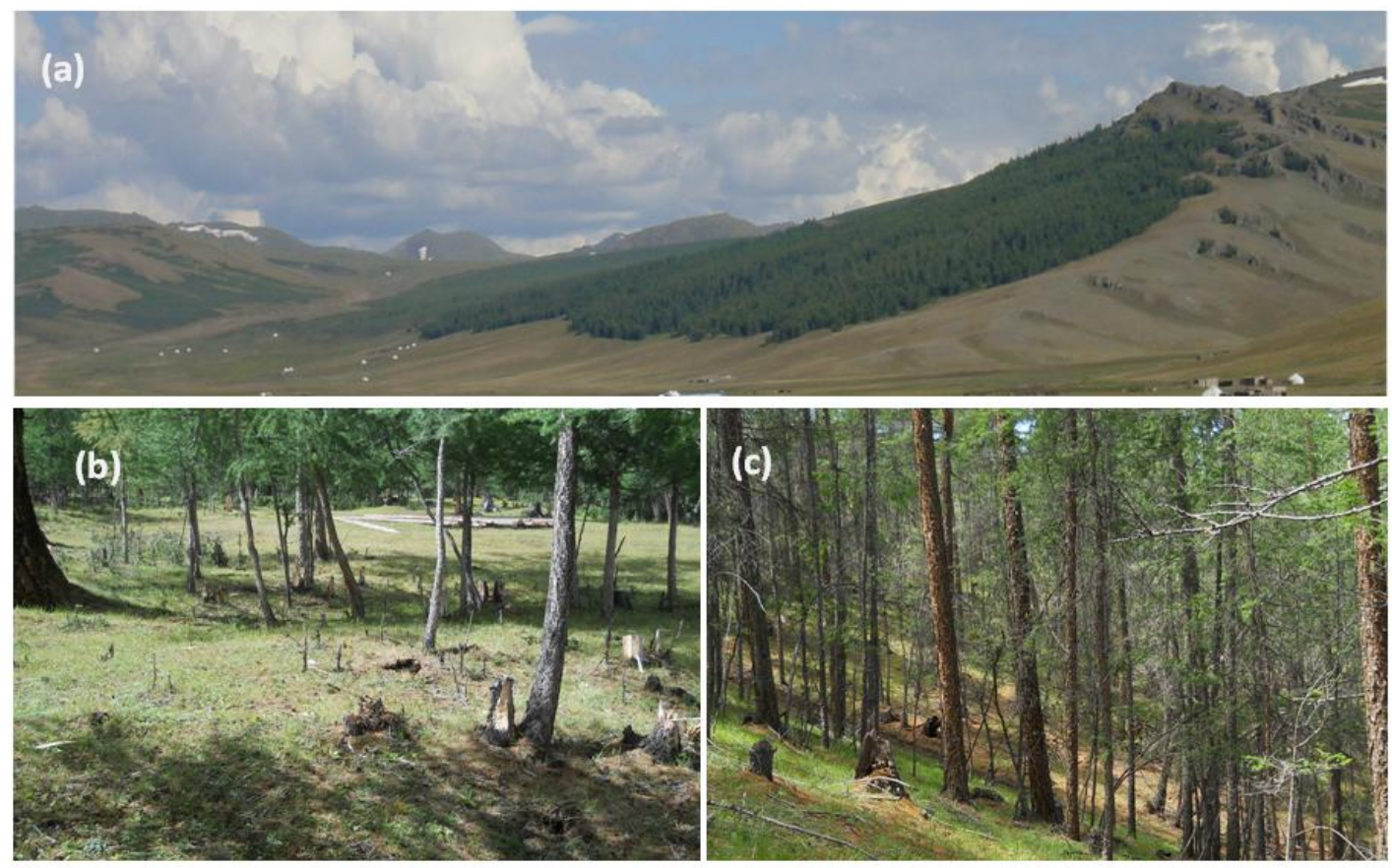

Fig. 1.5. Larch forest in Altai Mountains. (a) Studied forest distribution in north facing slope of Mountains. (b) forest edge and (c) forest interior (Photos: M.Khishigjargal) 


\subsection{Study objectives and hypotheses}

Although research progress has been made in recent years, main questions remain as how to forests are affected under significant climate changes as well as various intensive human activities such as livestock grazing and selective logging (as a result of the political and economic transformation process). The thesis is based on tree ring analysis and surveys of the presence for regeneration. This dissertation is subdivided into three studies.

In chapter 2, we quantify intra-annual and wood anatomy variability including climate response and growth trends of larch forest in Mt. Bogd Uul. We focus specifically on frequency of intra annual wood anatomy features and growth of middle and old aged larch trees in the forest interior and at the forest edge during recent decades.

In the chapter 3 and 4, recent trends in temperature and precipitation, tree radial stem increment; past and current regeneration as well as selective logging and intensive grazing influences on larch forest from Altai Mountains were analyzed.

The objective of these study were to analyze (1) climate effects on the trends of radial stem increment, (2) potential effects of logging on stem increment, (3) regeneration of Siberian larch and (4) livestock grazing on forest regeneration.

To achieve our objectives, we aimed to test the following hypotheses:

(1) Annual stem increment is primarily limited by summer drought (Chapter 2)

(2) The frequency of anomalies in wood anatomy has recently increased (Chapter 2)

(3) Climate warming has exerted an effect on the annual stem increment in the cold high- elevation environment of the Mongolian Altai (Chapter 3)

(4) Selective logging is influencing tree growth (Chapter 3)

(5) Present climate is not a major constraint for tree regeneration in the Mongolian Altai (Chapter 4).

(6) The density of tree seedlings and saplings decreases with increasing livestock density (Chapter 4). 


\section{References}

Adyasuren, Ts., 1998. Environment and Development Issues in Mongolia. Ulaanbaatar. (in Mongolian)

Allen, G.D., Macalady, A.K., Chenchouni, H., Bachelet, D., McDowell, N., Michel, V., Kitzberger,T., Rigling, A., Breshears, D.D., (Ted) Hogg, E.H., Gonzalez, P., Fensham, R., Zhang, Z., Castro, J., Demidova, N., Lim, J.H, Allard, G., Running, S.W., Semerci, A., Cobb, N., 2010. A global overview of drought and heat-induced tree mortality reveals emerging climate change risks for forests. Forest Ecology and Management 259, 660-684.

Antonova, F.G., Stasova, V.V., 1997. Effects of environmental factors on wood formation in larch (Larix sibirica $L d b$.) stems. Trees 11, 462-468.

D’Arrigo, R., G, Pederson, N., Frank, D., Buckley, B., Baatarbilig, B., Mijiddorj, R., Dugarjav, C., 2000. Mongolian tree-rings, temperature sensitivity and reconstructions of northern hemisphere temperature. Holocene 10, 669-672.

D'Arrigo, R.D., Frank, D., Jacoby, G.C., Pederson, N., 2001. Spatial response to major volcanic events in or about AD 536, 934 and 1258: frost rings and other dendrochronological evidence from Mongolia and northern Siberia: comment on R.B. Stothers, 'Volcanic dry fogs, climate cooling, and plague pandemics in Europe and the Middle East' (Climatic Change, 42, 1999). Climatic Change 49, 239-246.

D’Arrigo, R., Wilson, R., Liepert, B., Cherubini, P., 2008. On the divergence problem in northern forests: a review of the tree-ring evidence and possible causes. Global and Planetary Change 60, 289-305.

Batima, P., Natsagdorj, L., Gombluudev, P., Erdenetsetseg, B., 2005. Observed climate change in Mongolia. Assessments of impacts and adaptations of climate change. Workings papers 12, 1-26.

Boisvenue, C., Running, S.W., 2006. Impacts of climate change on natural forest productivity Evidence since the middle of the $20^{\text {th }}$ century. Global Change Biology 12 , 862-882.

Campi, A.J., 2011. Problems integrating Mongolia's nomads into a $21^{\text {st }}$ centery nation state. Nomadic civilizations in cross-cultural dialogue. ISBN978-99929-71-45-2, 383-390

Carlquist, S., 2001. Comparative wood anatomy (Systematic, Ecological, and Evolutionary Aspects of Dicotyledon Wood) Springer-Verlag Berlin Heidelberg. 
Dai, A., Trenberth, K.E., and Qian, T., 2004: A global data set of Palmer Drought Severity Index for 1870-2002: Relationship with soil moisture and effects of surface warming. Journal of Hydrometeorology 5, 1117-1130.

Dang, H., Jiang, M., Zhang, Y., Dang, G., Zhang, Q., 2008. Dendroecological study of a subalpine fir (Abies fargesii) forest in the Qinling Mountains, China. Plant Ecology 201 No1, 67-75.

Dagvadorj, D., Natsagdorj, L., Dorjpurev, J., Naymkhainyam, B., 2009. Mongolia Assessment report on climate change. Mongolian Ministry of Environment. Mongolia, Ulanbator. (in Mongolian)

De Grandpré, L., Tardif, J.C., Hessl, A., Pederson, N., Conciatori F., Green, T.R., Oyunsanaa, B., Baatarbileg, N., 2011. Seasonal shift in the climate responses of Pinus sibirica, Pinus sylvestris, and Larix sibirica trees from semi-arid, north central Mongolia. Canadian Journal of Forest Research 41, 1242-1255.

Dugarjav, Ch., 2006. Larch forest of Mongolia (in Mongolian). Bembi San, Ulan Bator.

Dulamsuren, Ch., Hauck, M., Mühlenberg., M., 2005. Vegetation at the taiga forest-steppe borderline in the western Khentei Mountains, northern Mongolia. Annales Botanici Fennici. 42, 411-426

Dulamsuren, Ch., Hauck, M., Bader, M., Osokhjargal, D., Oyungerel, Sh., Nyambayar, S., Runge, M., Leuschner. C., 2009. Water relations and photosynthetic performance in Larix sibirica growing in the forest-steppe ecotone of northern Mongolia. Tree Physiology 29, 99-110.

Dulamsuren, Ch., Hauck M., Khishigjargal, M., Leushner, H.H., Leuschner, C., 2010a. Diverging climate trends in Mongolian taiga forests influence growth and regeneration of Larix sibirica. Oecologia 163, 1091-1102.

Dulamsuren Ch., Hauck M., Leuschner, C., 2010b. Recent drought stress leads to growth reductions in Larix sibirica in the western Khentey, Mongolia. Global Change Biology 16, 30243035.

Dulamsuren, Ch., Hauck, M., Leuschner, H.H., Leuschner, C., 2010c. Gypsy moth-induced growth decline of Larix sibirica in a forest-steppe ecotone. Dendrochronologia 28, 207-213.

Dulamsuren, Ch., Hauck, M., Leuschner, H.H., Leuschner, C., 2011. Climate response of tree-ring width in Larix sibirica growing in the drought-stressed forest-steppe ecotone of northern Mongolia. Annals of Forest Science 68, 275-282. 
Eckstein, D., Bauch, J., 1969. Beitrag zur Rationalisierung eines dendrochronologischen Verfahrens und zur Analyse seiner Ausagesicherheit. Forstwissenschaftliches Centralblatt $88,230-250$.

Eckenwalder, J.E., 2009. Conifers of the world. The complete reference. Timber Press. Portland. London.

Erdenechuluun, T., 2006.Wood supply in Mongolia: legal and illegal economies. Mongolia Discussion papers. World bank. Washington, DC.

Fritts, H.C., 1976. Tree rings and climate. Academic press London.

Goodale, C.L., Apps, M.J., Birdsey, R.A., Field, B.C., Heath, S.L., Houghton, A.R., Jenkins, C.J., Kohlmaier, H.G., Kurz, W., Liu, S., Nabuurs, G., Nilsson, S., Shvidenko, Z.A., 2002. Forest carbon sinks in the northern hemisphere. Ecological Applications 12 (3), 891-899.

Gunin, P.D., 1999. Vostokova E.A., Dorofeyuk, N.I., Tarasov., Black, C.C., Vegetation dynamics of Mongolia. Kluwer, Dordrecht.

Guarin, A., Tayler, A.H., 2005. Drought triggered tree mortality in mixed conifer forests in Yosemite National Park, California, USA. Forest Ecology and Management 218, 229-244.

Hauck M., Javhlan S., Lhagvadorj D., Bayartogtoh B., Dulamsuren Ch., Christoph, L., 2011. Edge and land-use effects on epiphytic lichen diversity in the forest-steppe ecotone of the Mongolian Altai. Flora 207, 450-458.

Hauck, M., Dulamsuren, Ch., Heimes, C., 2008. Effects of a gypsy moth invasion on the performance of Larix sibirica in a forest-steppe ecotone of northern Mongolia. Environmental and Experimental Botany 62, 351-356.

Hasenauer, H., and Niemalä, P., 1999. Forest growth response to changing climate between 1961and 1990 in Austria. Forest Ecology and Management122, 209-212.

IPCC (Intergovernmental Panel on Climate Change) 2001. Climate change 2001: the scientific basis. Cambridge University Press, Cambridge.

IPCC (Intergovernmental Panel on Climate Change) 2007. Climate change 2007: The physical science basis. Summary for policymakers. Contributions of Working Group I to the fourth Assessment Report of the Intergovermental Panel on Climate Change. Geneva: WMO.

Kimmins, J.P., 2004. Forest ecology: a foundation for sustainable forest management and environmental ethics in forestry, Third Edition.ISBN0-13-066258-5. 
Kobelkov, M., 2008. National program on monitoring of large-area decline of boreal and temperate forests and minimization of its consequences with purpose of integration with the international plans of actions in connection with climate change. A Review of Science, Policie, and Practices", FAO/UFRO, Umeà, Sweden. 25-28 August.

Jacoby G.C., D’Arrigo R.D., Davaajamts T., 1996. Mongolian tree-rings and $20^{\text {th }}$-century warming. Science 273, 771-773.

Jacoby, G., D'Arrigo, R., Pederson, N., Buckley, B., Dugarjav, C., Mijiddorj, R., 1999. Temperature and precipitation in Mongolia based on dendroclimatic investigations. International Association of Wood Anatomists Journal 20, 339-350.

Jones, C., Lowe, J., Liddicoat, S., Betts, R., 2009. Committed terrestrial ecosystem changes due to climate change. Nature Geoscience 2, 484-487.

Joos, F., Prentice, I.C., House, J.I., 2002. Growth enhancement due to global atmospheric change as predicted by terrestrial ecosystem models: Consistent with US forest inventory data. Global change Biology 8, 299-303.

Lkhagvadorj, D., Hauck, M., Dulamsuren, Ch., Tsogtbaatar J., 2013. Pastoral nomadism in the forest-steppe of the Mongolian Altai under a changing economy and warming climate. Arid Environments 88, 83-89.

MacDonald, G.M., Kremenetski, K.V., Beilman, D.W., 2008. Climate change and the northern Russian treeline zone. Philosophical Transactions of the Royal Society B: Biological Sciences 363, 2283-2299.

Meko, M.D., Baisan, H.C., 2001. Pilot study of latewood-width of conifers as an indicator of variability of summer rainfall in the North American Monsoon Region. International Journal of Climatology21, 697-708.

Nandintsetseg, B., Green, J.S., Coulden, C.E., 2007. Trends in extreme daily precipitation and temperature near Lake Hövsgöl, Mongolia. Journal of Climate 27, 341-347

National Atlas of BNMAU. 1990. Ulaanbaatar-Moskva. (in mongolian)

Oberhuber,W., 2004. Influence of climate on radial growth of Pinus cembra within the alpine timberline ecotone. Tree Physiology 24, 291-301

Park, Y. D., Lee, D.J., Tsogtbaatar, J., John, A. S., Batkhuu, N., Park, D., 2007. Strategies for succesful ecological restoration of degraded forest ecosystem in Mongolia. IUFRO Conference on Forest Landscape Restoration-Seoul, Korea May 14-19. 
Pederson, N., Jacoby, G.G., Arrigo, R.R, Cook, E.R, Buckley, B.M., 2001. Hydrometeorological reconstructions for north eastern Mongolia derived from tree rings:1651-1995. Journal of Climate14, 872-881.

Report of Ministry of Environment and Tourism, 2009-2010. Ulaanbaatar. p33. (in Mongolian)

Ruday, N.A., Tarasov, P.E., Dorofuyek, N., et al., 2008. Environmental changes in the Mongolian Altai during the Holocene. Archaeol Ethnol Anthropol Eurasia 36, 2-14

Sankey T.T., Montagne, C., Graumlich, L., Lawrence, R., Nielsen, J., 2006. Lower forest grassland ecotones and $20^{\text {th }}$ century livestock herbivory effects in northern Mongolia. Forest Ecology and Management 233, 36-44

Sarantuya G., Natsagdorj L., 2010. Climate change in Mongolia. IGES conference report-Regional centre-2011-01. Proseedling of Consultative Meeting on Integration of Climate Change Adaptation into sustainable Development in Mongolia. (www.iges.or.jp)

Seager, R., Ting, M., Held, I., Kushnir, Y., Lu, J., Vecchi, G., Huang, H.P., Harnik, N., Leetmaa, A., Lau, N.C., Li, C., Velez, J., Naik, N., 2007. Model projections of an imminent transition to a more arid climate in southwestern North America. Science 316, 1181-1184.

Schweingruber F.H., 2007. Tree rings. Wood Structure and Environment. ISBN-13 978-3-54048229-4. Springer, Berlin.

Schweingruber, F.H., 1988. Tree Rings: Basics and Applications of Dendrochronology. D. Reidel, Dordrecht, The Netherlands.

Tardif, C.J., Girardin, P.M., Conciatori, F., 2011. Light rings as bioindicators of climate change in Interior North America. Global and Planetary Change 79, 134-144

Tsegmid, Sh. (1969). Physical geography of Mongolia. Ulsyn Khevleliin Gazar, Ulaanbaatar. (in Mongolian)

Treter, U., 2000. Stand structure and growth patterns of the larch forests of western Mongolia dendrochronological approach. Berliner Geowissenshaftliche Abhandlungen A205, 60-66.

Tsogtbaatar, J., 2004. Deforestation and reforestation needs in Mongolia. Forest Ecology and Management 201, 57-63.

UNESCO World Heritage Website (1996): http://whc.unesco.org/en/tentativelists/936/

Vagonov, A.E., Anchukaitis, K.J., Evans, N.M., 2011. How well understood are the process that create dendroclimatic records? A mechanistic Model of the Climatic Control on conifer tree-ring growth dynamics. Dendroclimatology Volume 11, 42-50. 
Wilmking, M., Juday, G.P., Barber, V.A., Zald, H.S.J., 2004. Recent climate warming forces contrasting growth responses of white spruce at tree line in Alaska through temperature thresholds. Global Change Biology 10, 1724-1736.

Wimmer, R., 2002. Wood anatomical features in tree-rings as indicators of environmental change. Dendrochronologia 20/1-2, 21-36.

Ykhanbai, H., 2010. Mongolia forestry outlook study. Asia-Facific forestry sector outlook study II. Working paper series. N APFSOSII/WP/2009/21 FAO. Bangkok, 2010. 


\section{CHAPTER}

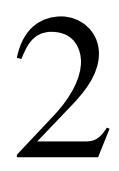

\section{CLIMATE EFFECTS ON INTER- AND INTRA-ANNUAL LARCH STEMWOOD ANOMALIES IN THE MONGOLIAN FOREST-STEPPE}

Mookhor Khishigjargal, Choimaa Dulamsuren, Hanns Hubert Leuschner, Christoph Leuschner and Markus Hauck

Submitted to Acta Oecologica. 


\section{Abstract}

Climate response of tree-ring width and intra-annual wood anomalies were studied in stands of Siberian larch (Larix sibirica) on Mt. Bogd Uul in the forest-steppe ecotone of Mongolia. Climate on Mt. Bogd Uul is characterized by an increase of the annual mean temperature by $1.5 \mathrm{~K}$ between 1965 and 2007 at constant annual precipitation and, with it, an increase in aridity. Tree-ring width increases with increasing June precipitation of the current year (June) and increasing late summer precipitation of the previous year. In >100-year old trees, also a negative correlation of tree-ring width with the July temperature of the year prior to tree-ring formation was found. Decreasing tree-ring width with increasing snowfall in December can be explained with the protection of the frost-sensitive eggs of gypsy moth by snow cover, which is a major herbivore for larch in the Mongolia and causes reduction in the annual stem increment. The most significant change in wood anatomy was the decline of wide latewood, which is attributable to the increase of summer days with a mean temperature $>15{ }^{\circ} \mathrm{C}$ and drought periods in summer without precipitation. Increasing summer drought is also thought to have caused the repeated occurrence of missing rings since the 1960 s, which were not observed in the late $19^{\text {th }}$ and early $20^{\text {th }}$ century.

Keywords: Global warming, forest-steppe, Larix sibirica, drought stress, latewood, missing rings 


\subsection{Introduction}

Forest-steppe ecotones of semiarid Central and North-Eastern Asia have recently attracted increased attention, because the forests in this biome respond sensitively to changes in temperature and precipitation. Therefore, Mongolian forests have been popular study objects for climate reconstructions (Jacoby et al., 1999; D'Arrigo et al., 2000; Pedersen et al., 2001; Davi et al., 2010). Tree-ring chronologies from the Mongolian forest-steppe derived from live conifers cover more than 660 years (Davi et al., 2006); combined with conserved deadwood the oldest chronology includes a period of 1700 years (D'Arrigo et al., 2001a). Tree-ring widths were correlated with temperature, precipitation and streamflow. Some other studies analyze relationships of climate with the annual stem increment to detect global warming responses of the forest ecosystems and partly also include the study of trends in forest regeneration (Jacoby et al., 1996; Dulamsuren et al., 2010a,b; De Grandpré et al., 2011). Both the stimulation and the inhibition of annual stem increment along with Mongolia's rapidly changing climate have been reported.

Only few studies conducted in Mongolia's forest-steppe ecotone addressed the effect of climate on intra-annual wood-anatomical features. D'Arrigo et al. (2001b) found the occurrence of frost rings to be a more sensitive indicator of temporary climate cooling than tree-ring width. De Grandpré et al. (2011) established that false rings were correlated with summer drought and light rings were indicators of a cold late summer. This background motivated us to analyze the effect of temperature and precipitation on tree-ring width and the occurrence of intra-annual woodanatomical features in trees of Siberian larch (Larix sibirica Ledeb.), which is Mongolia's most widespread tree species covering $80 \%$ of the country's forested area (Tsogtbaatar, 2004). The study objective was to test the hypotheses that (1) annual stem increment is primarily limited by summer drought and (2) the frequency of anomalies in wood anatomy has recently increased. A limiting effect of summer drought on tree-ring width would suggest that tree radial growth should be sensitive to increasing aridity in the course of climate warming, given the semiarid climate of the study area, while a recent increase in the occurrence of striking wood-anatomical features would suggest that climate warming already has resulted in anomalies in wood formation. 


\subsection{Material and methods}

\subsubsection{Study area}

The study was carried out on Mt. Bogd Uul, which represents the most south-westerly extension of the Khentei Mountains and covers an altitudinal range between 1400 and $2268 \mathrm{~m}$ a.s.l. The study sites (Fig. 2.1) were located on the eastern flank of the Mt. Bogd Uul massif west of the Shajin Khurkh valley at 1800 to $1900 \mathrm{~m}$ a.s.1. (4746' N, 107²' E), $12 \mathrm{~km}$ southeast of Ulan Bator. More than half of the total area of Mt. Bogd Uul (i.e. $230 \mathrm{~km}^{2}$ ) is forested with Siberian larch (Larix sibirica) which dominates at lower elevation on $57 \%$ of the forested area (Adiyasuren, 1997). At the studied elevations of Mt. Bogd Uul, north-facing slopes are generally covered with larchdominated forest, whereas the south-facing slopes are vegetated with grasslands (Hilbig et al., 2004). On its southern flank, the Mt. Bogd Uul massif abruptly adjoins to the central Mongolian steppe; Mt. Bogd Uul harbors the southernmost forests in this region of Mongolia.

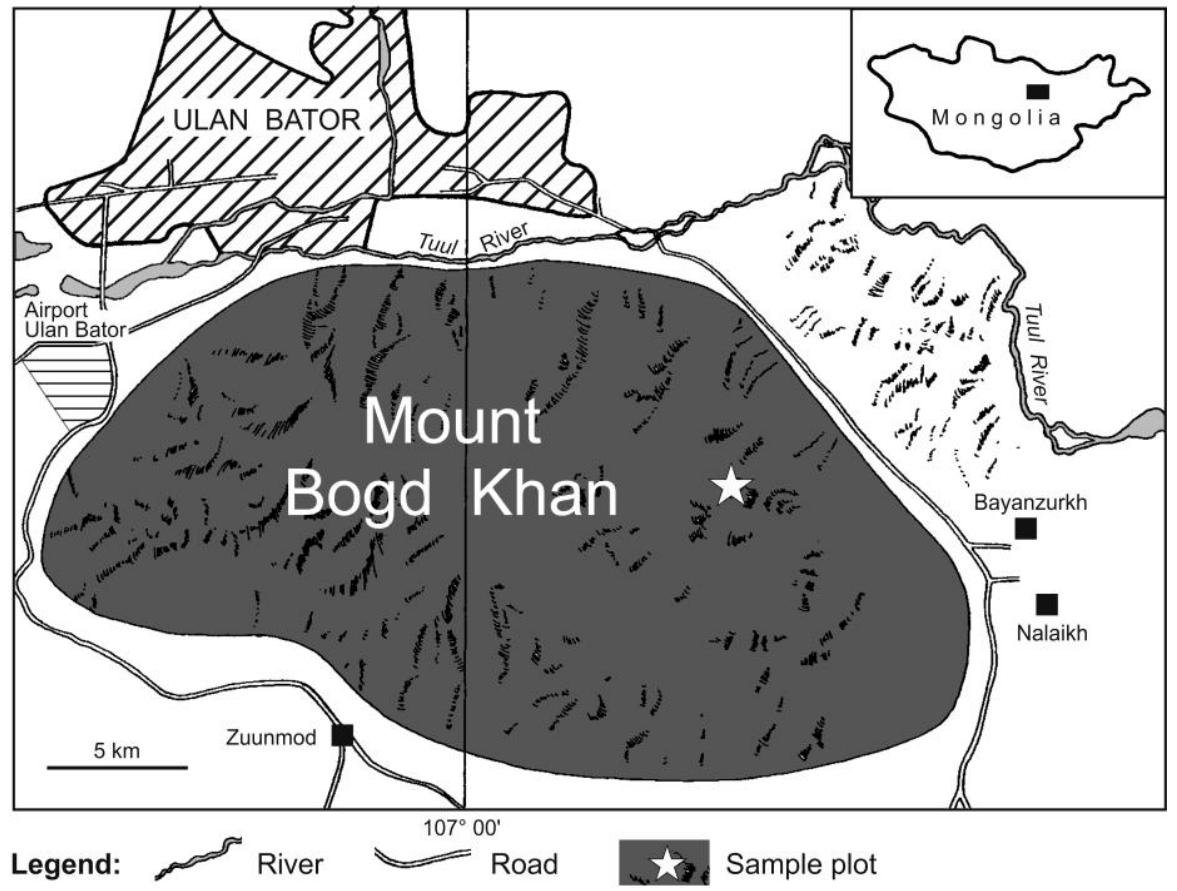

Fig. 2.1. Map of the study area on Mt. Bogd Uul in the southern Khentei, Mongolia. The study areas is marked with an asterisk.

Forests in Mongolia's forest-steppe ecotone have been affected by persistent selective logging, fuel-wood collection, anthropogenic fire and livestock grazing over long periods (Hessl et al., 
2012; Lkhagvadorj et al., 2013). Mt. Bodg Uul is one of the world's oldest formally protected conservation areas (established in 1778 when the nearby city of Ulan Bator became the Mongolian capital); the conservation area was established after Mt. Bogd Uul had been subjected to protection by the Mongolian Khans (kings) already since the $13^{\text {th }}$ century (Barkmann, 2000). Conservation included the banning of logging, fuel-wood collection and hunting. Approximately since the time of formal protection in the late $18^{\text {th }}$ century, forest fires ceased to occur on Mt. Bogd Uul, which are otherwise frequent in the Mongolian forest-steppe (Hessl et al., 2012). Hessl et al. (2012) explained the nonappearance of fire since the late $18^{\text {th }}$ century with increased fuel-wood collection and increased forest grazing due to the increasing human population of Ulan Bator, an explanation which is in conflict with the conservation status but might be correct. An alternative explanation would be effective fire suppression.

\subsubsection{Wood core sampling and laboratory work for tree-ring analysis}

Field work was carried out in October 2007. Five sample plots of $20 \mathrm{~m}$ x $20 \mathrm{~m}$ were selected with a minimum distance from one another of $1 \mathrm{~km}$. The plots were selected non-randomly to represent typical larch forest stands on north-facing slopes and for avoiding moist depressions. All plots were located at least $50 \mathrm{~m}$ distant from the forest edge in the forest interior. To analyze differences between the forest interior and the forest edge, south-exposed forest edges, which bordered to the steppe, were additionally studied. In case of the forest edge plots, the nearest forest line to the respective forest interior plot was selected. Here, trees growing directly at the forest line were selected in a $50 \mathrm{~m}$-long section. Wood-core samples were collected from all trees on the sample plots using an increment borer with an inner diameter of $5 \mathrm{~mm}$. The borer was driven into the wood parallel to the contour lines of the slope at $1.3 \mathrm{~m}$ height above the ground. Additional treerelated data, including the social rank within the forest stand, were recorded in the field.

In the laboratory, wood cores were mounted on grooved wooden strips and cut lengthwise by hand using scalpels. The contrasts between annual tree-rings were enhanced with chalk. Data recording and their evaluation was conducted with TSAP (Time Series Analysis and Presentation)Win software (Rinntech, Heidelberg, Germany). Annual tree-ring width was measured with a precision of $10 \mu \mathrm{m}$ on a movable object table (Lintab 5). The quality of the measurements was 
controlled and missing rings were detected, by crossdating, among others by identifying local pointer years (Meyer, 1999). Crossdating allows the exact age dating of each tree ring, as it not only helps to identify overlooked hardly distinguishable tree rings, but also detects the years when no tree ring was formed (Fritts, 1976; Schweingruber, 1988). Crossdating was based on the use of two parameters: coefficient of agreement ('Gleichläufigkeit' [GL]) (Eckstein \& Bauch, 1969) and (standard) $t$-values. The $G L$ - and $t$-values measure the similarity between tree-ring series in the high- and low-frequency domain, respectively. Standardization of the tree ring series was achieved by applying the equation $\mathrm{z}_{\mathrm{i}}=\mathrm{w}_{\mathrm{i}} / \mathrm{m}_{\mathrm{i}}$ with $\mathrm{z}_{\mathrm{i}}$ being the standardized ring width, $\mathrm{w}_{\mathrm{i}}$ the absolute treering width, and $\mathrm{m}_{\mathrm{i}}$ the 10-yr moving average of year $\mathrm{i}$; moving averages keep much of the interannual (high-frequency) variation and remove much of the long-term (low-frequency) variation. Two age classes were distinguished and included in the analysis, separating 'middleaged' trees with the oldest tree ring being between 60 and 100 years old from 'old' trees with the oldest tree ring being >100 years old. Younger trees were excluded from the analysis. About 10 (at most 20) years should be added to deduce tree age from the presented specification of cambium age at sampling height (Körner et al., 2005; Sankey et al., 2006). Tree-ring series were representative of the studied stands as shown by the calculation of the expressed population signal (EPS) using sums of squares of within-core variation and error sums of squares calculated in a two-way analysis of variance (ANOVA) (Wigley et al., 1984). The EPS calculated separately for the age group and the habitat (forest interior vs. edge) clearly exceeded the 0.85-threshold in all groups of trees, as can be taken together with other simple descriptive statistics of the tree-ring series from Table 2.1. Year-to-year variability of tree-ring width was expressed as mean sensitivity, as was the influence of the increment in the previous year on the increment of the current year as first-order autocorrelation coefficient (Fritts, 1976). Mean sensitivity and autocorrelation coefficients were calculated over the whole lifespan of each sample tree.

Table 2.1. Descriptive statistics of the tree-ring series from the interior and edge of Larix sibirica forests on Mt. Bodg Uul including the total number of sample trees $(N)$, the cambial age, the mean ring width and the expressed population signal (EPS).

\begin{tabular}{llllllll}
\hline Habitat & Age class $(\mathrm{yr})$ & $N$ & \multicolumn{2}{c}{ Cambial age $(\mathrm{yr})$} & Mean ring width (mm) & EPS \\
\cline { 5 - 6 } & & & Mean & Min. & Max & \\
\hline Interior & $>100$ & 65 & $119 \pm 2$ & 100 & 146 & $1.06 \pm 0.05$ & 0.97 \\
Interior & $60-100$ & 67 & $73 \pm 1$ & 63 & 80 & $1.25 \pm 0.10$ & 0.99 \\
Edge & $60-100$ & 42 & $75 \pm 0$ & 64 & 93 & $1.52 \pm 0.12$ & 0.98 \\
\hline
\end{tabular}




\subsubsection{Study of wood-anatomical features}

The individual tree rings $(N=14922)$ of all sample trees with a cambial age of at least 60 years $(N=174)$ were analyzed for anomalies in wood anatomy. Since the frequency of some woodanatomical features changes with age (Meko and Baisan, 2001; Crawford, 2012), we mostly restricted the study interval for analyzing changes in the frequency of wood anatomical-features over time to the period from 1957-2007, thereby including 8874 tree rings. Changes in the cumulative frequency of any kind of wood-anatomical features was even limited to the period from 1997-2007. Only for few wood-anatomical features where there is indication that they are little dependent on tree age, we refer to a longer period from 1870-2007; these cases are explicitly mentioned in the Results and justified in the Discussion. The potential age bias was further controlled by analysis wood-anatomical features separately for different age classes. Woodanatomical features were classified following the concepts of Leuschner and Schweingruber (1996). Definitions for and putative causes of the studied wood-anatomical anomalies are compiled in Table 2.2. The wood cores were studied with a Stereo Discovery V20 dissecting microscope (Carl Zeiss, Jena, Germany) at a magnification of up to $60 \times$. For photographs, wood microsections were cut with a microtome, stained with astra blue and safranine and studied with a compound microscope. 
Table 2.2. Definition and putative causes of studied intra-annual wood-anatomical features (after Leuschner and Schweingruber, 1996).

\begin{tabular}{|c|c|c|}
\hline Anomaly & Symptoms & Causes \\
\hline Frost ring & $\begin{array}{l}\text { Deformed tissue, not arranged in } \\
\text { regular rows in the earlywood }\end{array}$ & $\begin{array}{l}\text { Damage of the cambium or growing } \\
\text { earlywood due to frost }\end{array}$ \\
\hline $\begin{array}{l}\text { Density } \\
\text { fluctuations }\end{array}$ & $\begin{array}{l}\text { Intra-annual layers of varying } \\
\text { wood density due to variations in } \\
\text { cell size and cell wall thickness }\end{array}$ & $\begin{array}{l}\text { Periodic stress during the growing season, } \\
\text { especially drought stress }\end{array}$ \\
\hline Dense latewood & $\begin{array}{l}\text { High density of latewood with } \\
\text { thick cell walls causing a dark } \\
\text { coloration }\end{array}$ & $\begin{array}{l}\text { Above-average carbon assimilation during } \\
\text { the mid-growing season due to favorable } \\
\text { growth conditions }\end{array}$ \\
\hline Light latewood & $\begin{array}{l}\text { Low density of latewood with } \\
\text { thin cell walls and light } \\
\text { coloration }\end{array}$ & $\begin{array}{l}\text { Reduced carbon assimilation during the mid- } \\
\text { growing season due to unfavorable growth } \\
\text { conditions }\end{array}$ \\
\hline $\begin{array}{l}\text { Narrow } \\
\text { latewood }\end{array}$ & $\begin{array}{l}\text { Exceptionally narrow latewood } \\
\text { (at least } 70 \% \text { narrower than } \\
\text { average) }\end{array}$ & Extremely unfavorable growing season \\
\hline Wide latewood & $\begin{array}{l}\text { Exceptionally wide latewood (at } \\
\text { least } 70 \% \text { wider than average) }\end{array}$ & $\begin{array}{l}\text { Growing season with favorable weather } \\
\text { conditions }\end{array}$ \\
\hline Collapsed cells & $\begin{array}{l}\text { Ring with collapsed cells, } \\
\text { completely compressed cells in } \\
\text { the earlywood }\end{array}$ & $\begin{array}{l}\text { Extreme sudden changes in temperature } \\
\text { during the beginning of growing season }\end{array}$ \\
\hline $\begin{array}{l}\text { Resin ducts in } \\
\text { earlywood }\end{array}$ & $\begin{array}{l}\text { Occurrence of several resin ducts } \\
\text { in the earlywood }\end{array}$ & $\begin{array}{l}\text { Response to mechanical damage, late frost or } \\
\text { otherwise unfavorable weather conditions in } \\
\text { the early growing season }\end{array}$ \\
\hline $\begin{array}{l}\text { Resin ducts in } \\
\text { latewood }\end{array}$ & $\begin{array}{l}\text { Occurrence of several resin ducts } \\
\text { in the latewood }\end{array}$ & $\begin{array}{l}\text { Response to mechanical damage or } \\
\text { unfavorable weather conditions in the mid- } \\
\text { growing season }\end{array}$ \\
\hline Reaction wood & $\begin{array}{l}\text { Thick-walled tracheids and thin- } \\
\text { walled parenchyma }\end{array}$ & $\begin{array}{l}\text { Response to changes in the position of the } \\
\text { tree which have influenced gravity balancing } \\
\text { (e.g. due to landslide or storm) or to changes } \\
\text { in the light climate }\end{array}$ \\
\hline Missing ring & $\begin{array}{l}\text { Tree-ring completely absent } \\
\text { (identified by crossdating) }\end{array}$ & $\begin{array}{l}\text { Lack of cambial activity due to extremely } \\
\text { unfavorable growth conditions }\end{array}$ \\
\hline
\end{tabular}

\subsubsection{Climate data and climate-response analysis}

Climate data for the climate-response analysis were used from the two nearest weather stations

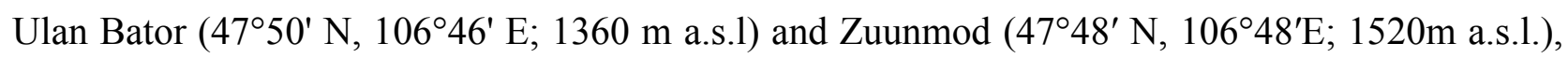
which are located $30 \mathrm{~km}$ northwest and $15 \mathrm{~km}$ southwest of the studied forest stands, respectively. Data from Ulan Bator are available since 1940 and from Zuunmod since 1965. The weather station 
Zuunmod is located south of the forested area of Mt. Bogd Uul and is much more influenced by the central Mongolian steppe climate than the weather station Ulan Bator, which is located in the broad valley of the Tuul River within the forest-steppe zone. Nevertheless, correlations of tree-ring width or the frequency of wood-anatomical features turned out to be stronger with the climate data from the closer weather station Zuunmod than from Ulan Bator. Therefore, the data from Ulan Bator were only used to analyze climate trends, but not for climate-response analysis. Thus, all climate-response analyses refer to Zuunmod and the period from 1965 to 2007.

The relationship of tree-ring width with annual mean temperature and monthly precipitation of the current year and the year prior to tree-ring formation was analyzed calculating Pearson's correlation coefficients. The frequency of specific wood-anatomical features was correlated with the frequency of days or periods with certain climate conditions in individual months. These climate characteristics included (1) the total number of days with a mean temperature $<0{ }^{\circ} \mathrm{C}$, (2) a mean temperature $<-5{ }^{\circ} \mathrm{C}$, or (3) a mean temperature $>15{ }^{\circ} \mathrm{C}$, (4) the number of days with daily mean temperature exceeding the long-term (1965-2007) mean temperature of the relevant month, (5) the number of continuous 5-day periods without precipitation, and (6) the number of continuous 15-day periods without precipitation. The effect of these climate parameters on the frequency of wood-anatomical features was analyzed with multiple regression analysis.

\subsubsection{Statistics}

Means, which are presented \pm standard errors throughout the paper, were tested for statistically significant differences using Duncan's multiple range test, after testing for normal distribution with the Shapiro-Wilk test. These analyses and the above-mentioned ANOVAs for calculating the EPS and regression analyses were calculated with SAS 9.13 software (SAS Institute Inc., Cary, North Carolina, U.S.A.). 


\subsection{Results}

\subsubsection{Climate trends}

The annual mean temperature was $-2.5 \pm 0.2{ }^{\circ} \mathrm{C}$ at the weather station Ulan Bator and $1.3 \pm 0.2{ }^{\circ} \mathrm{C}$ at the weather station Zuunmod between 1965 and 2007. The mean July temperature was $17{ }^{\circ} \mathrm{C}$ in Ulan Bator and $16{ }^{\circ} \mathrm{C}$ in Zuunmod between 1965 and 2007, whereas the mean January temperatures amounted to $-26{ }^{\circ} \mathrm{C}$ and $-20{ }^{\circ} \mathrm{C}$, respectively. The warmer winters in Zuunmod explain the higher annual mean temperature despite of the higher altitude than in Ulan Bator. Assuming a temperature lapse rate of $6.5 \mathrm{~K} \mathrm{~km}^{-1}$, the $160 \mathrm{~m}$-altitudinal distance would result in a by $1.0 \mathrm{~K}$ higher annual mean temperature in Ulan Bator than in Zuunmod The mean annual temperature has increased by $1.5 \mathrm{~K}$ at both weather stations between 1965 and 2007 (Fig. 2.2a), while the temperature increase in Ulan Bator between 1940 and 2007 was $2.5 \mathrm{~K}$.

The mean annual precipitation (1965-2007 period) in Zuunmod (271 $\pm 14 \mathrm{~mm})$ exceeded that in Ulan Bator $(179 \pm 11 \mathrm{~mm})$ by $92 \mathrm{~mm}$. The considerable interannual variation of precipitation is reflected by annual totals ranging from 72 to $321 \mathrm{~mm}$ in Ulan Bator and from 161 to $450 \mathrm{~mm}$ in Zuunmod. No significant change in annual precipitation was detected in the period covered by climate data in Ulan Bator and Zuunmod (Fig. 2.2b). 


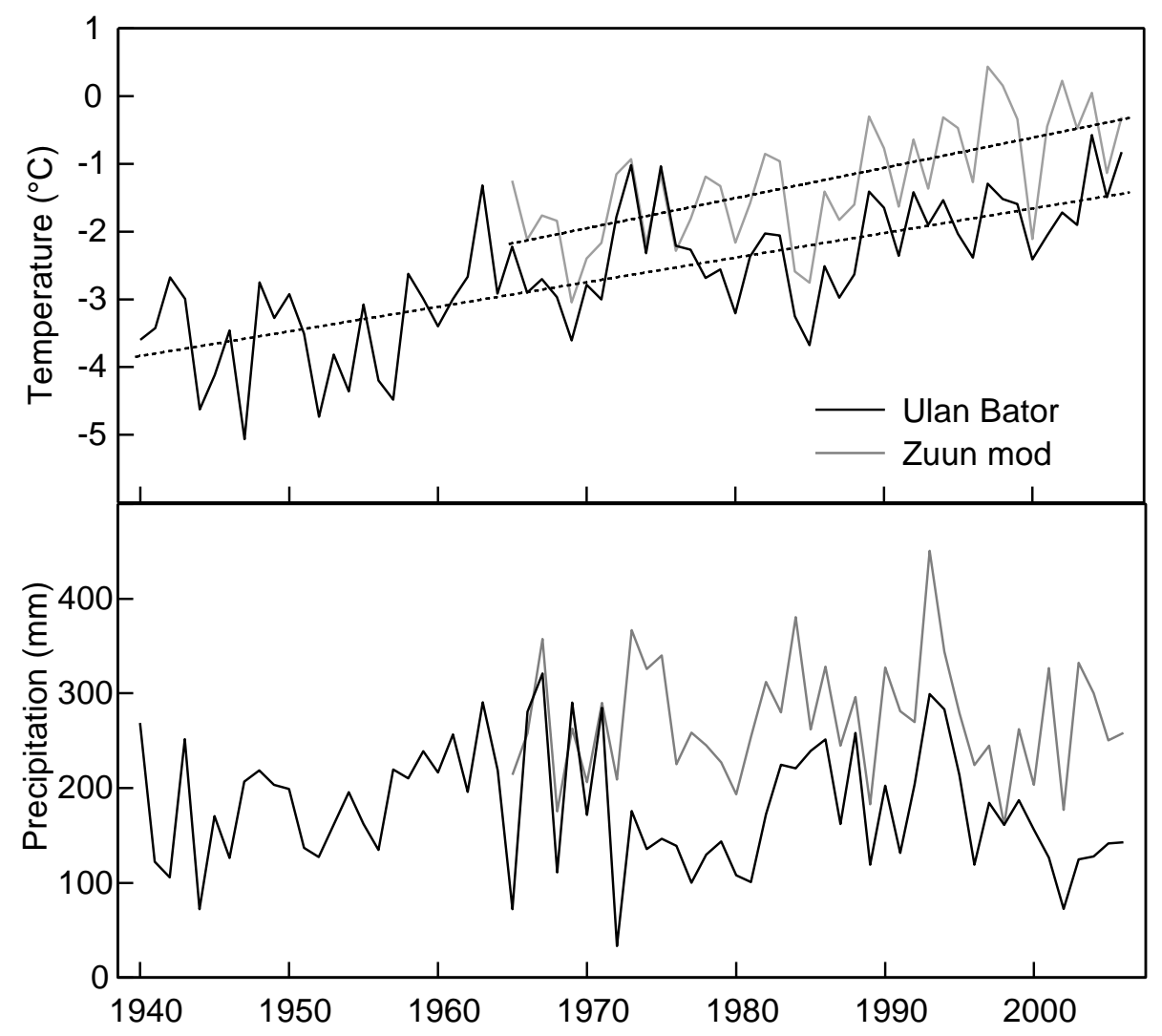

Fig.2.2. Climate trends at the weather stations Ulan Bator (1360 m a.s.1.) and Zuunmod (1520 m a.s.1.). (a) Mean annual temperature in Ulan Bator (since 1940; $\mathrm{r}=0.75, P<0.001$ ) and Zuunmod (since 1965; $\mathrm{r}=0.63, P<0.001$ ). (b) Mean annual precipitation $(P>0.05)$.

\subsubsection{Tree-ring chronologies and climate response of tree-ring width}

The oldest trees included in the analysis established in the mid $19^{\text {th }}$ century (Fig. 2.3). Trees at the forest edge were younger than in the forest interior; trees more than 100 years old were even absent on the edge. The mean sensitivity of tree-ring width was higher at the forest edge than in the forest interior and, in the forest interior, higher in middle-aged than old trees (Table 2.3). The higher mean sensitivity at the forest edge than in the forest interior corresponded to higher correlation coefficients at the forest edge in the climate-response analysis (Fig. 2.4) and higher first-order autocorrelation coefficients in the forest interior. In all analyzed tree collectives (old and middle-aged tress in the forest interior, middle-aged trees at the forest edge), June precipitation of the current year and the precipitation in the late growing season of the year prior to tree-ring 
formation were positively correlated with tree-ring width. Pertaining to the previous year, significant correlations with precipitation were partly found with the precipitation in August and partly with that in September or of both months. The December precipitation was negatively correlated with tree-ring width in all tree collectives, though the correlation was closer at the forest edge than in the forest interior. At the forest edge, tree-ring width also decreased with increasing July temperatures of the previous year.

Table 2.3. Mean sensitivity and first-order correlation coefficients for Larix sibirica from the forest interior and forest edge. ${ }^{a}$

\begin{tabular}{llll}
\hline Habitat & Age class $(\mathrm{yr})$ & Mean sensitivity & Autocorrelation \\
\hline Interior & $>100$ & $0.45 \pm 0.01 \mathrm{a}$ & $0.75 \pm 0.01 \mathrm{a}$ \\
Interior & $60-100$ & $0.53 \pm 0.01 \mathrm{~b}$ & $0.76 \pm 0.01 \mathrm{a}$ \\
Edge & $60-100$ & $0.62 \pm 0.02 \mathrm{c}$ & $0.62 \pm 0.02 \mathrm{~b}$ \\
\hline
\end{tabular}

${ }^{\text {a }}$ Within a column, means followed by the same letter do not differ significantly (Duncan's multiple range test, $P \leq 0.05$, $\left.\mathrm{df}_{\text {model }}=2, \mathrm{df}_{\text {error }}=171\right)$.

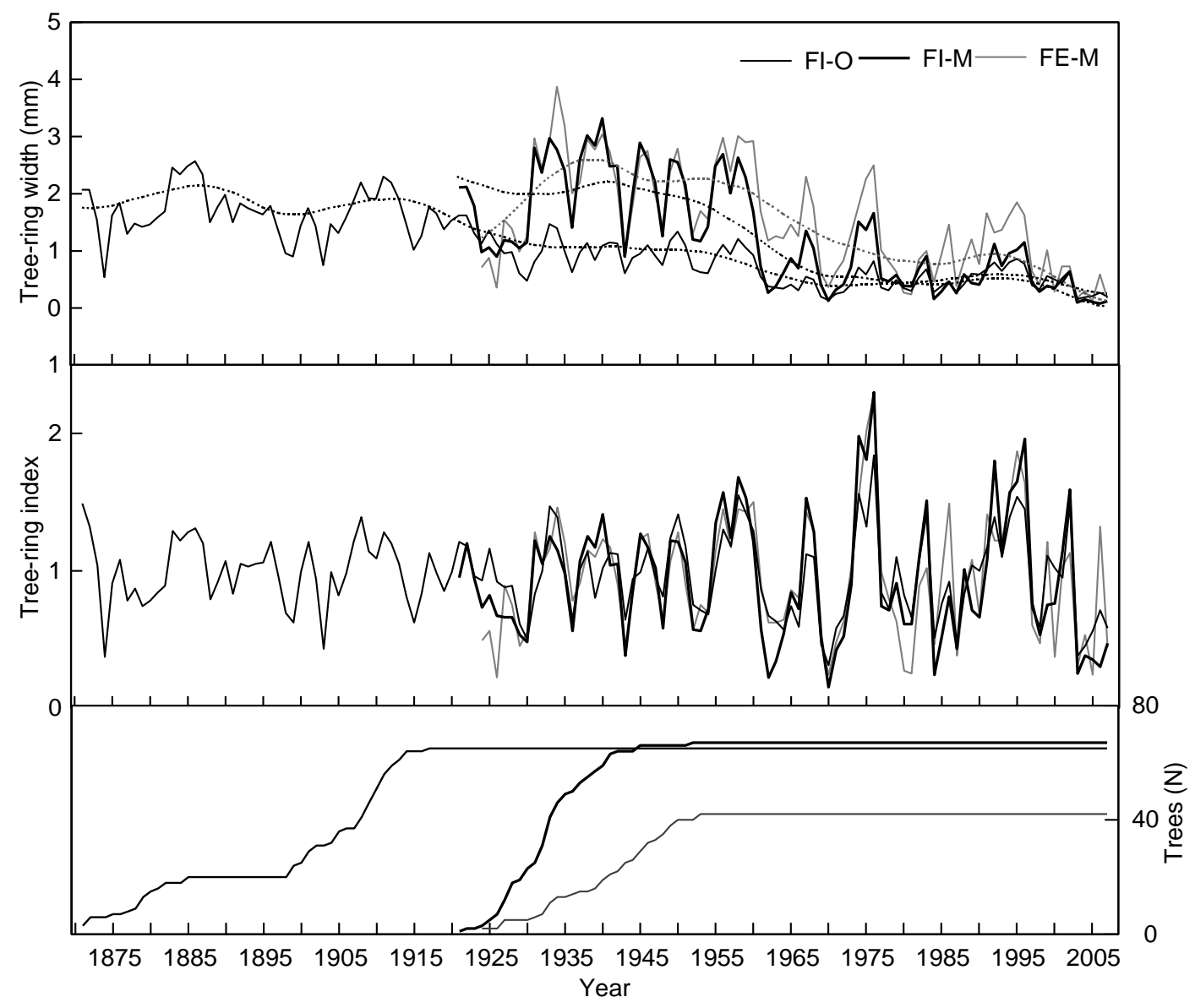

Fig.2.3. Tree-ring chronologies for Larix sibirica trees from the forest interior and the forest edge (a) Tree-ring width. (b) Tree-ring index. (c) Number of samples. FI-O, forest interior, old trees (>100 yr), FI-M, forest interior, middleaged trees (60-100 yr), FE-M, forest edge, middle-aged trees (60-100 yr). 


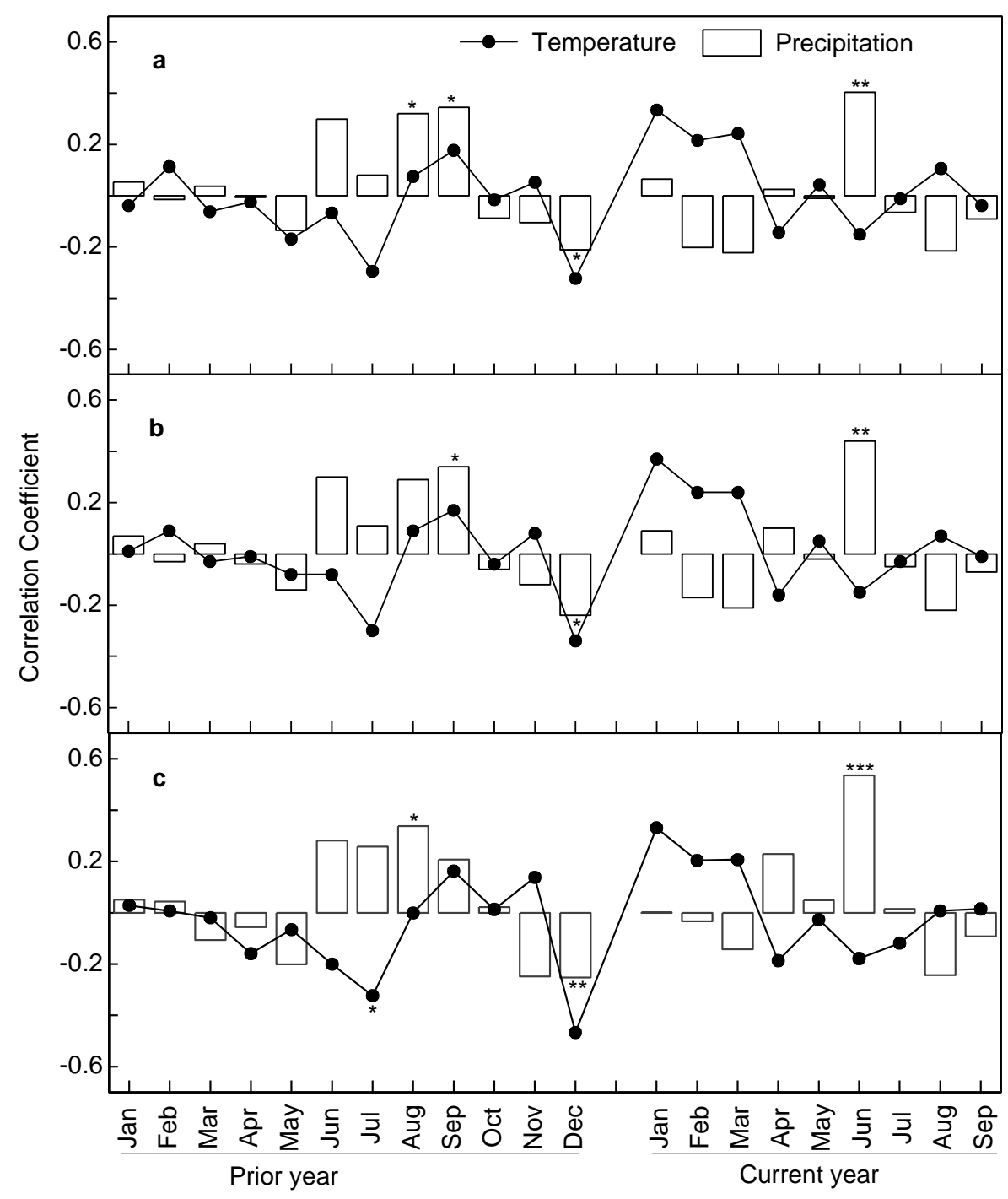

Fig. 2.4. Response of tree-ring width in Larix sibrica to monthly means of temperature and precipitation of the year of and the year prior to tree-ring formation. (a) Forest interior, $>100-y r$ old trees. (b) Forest interior, 60-100-yr old trees. (c) Forest edge, 60-100-yr old trees. Pearson's correlation coefficients; * $P \leq 0.05$, ** $P \leq 0.01$.

\subsubsection{Wood-anatomical features}

The eleven wood-anatomical features defined in Table 2 could well be recognized in the studied wood cores of L. sibirica (Fig. 2.5). The wood of nearly all 174 analyzed trees revealed intraannual wood-anatomical anomalies (Table 2.4). One-third of the tree-rings from middle-aged trees and $26 \%$ of the tree-rings from old trees showed intra-annual features. Narrow latewood, which occurred in $12 \%$ of the studied tree rings, was the most frequent wood-anatomical feature. All other wood-anatomical features were found in less than $5 \%$ of the tree rings; these wood- 
anatomical features included wide latewood (4\%), dark latewood (3\%), resin ducts in latewood or earlywood, density fluctuations, light latewood, and missing rings (all $2 \%$ ). Even less frequent were collapsed cells, reaction wood and frost rings.
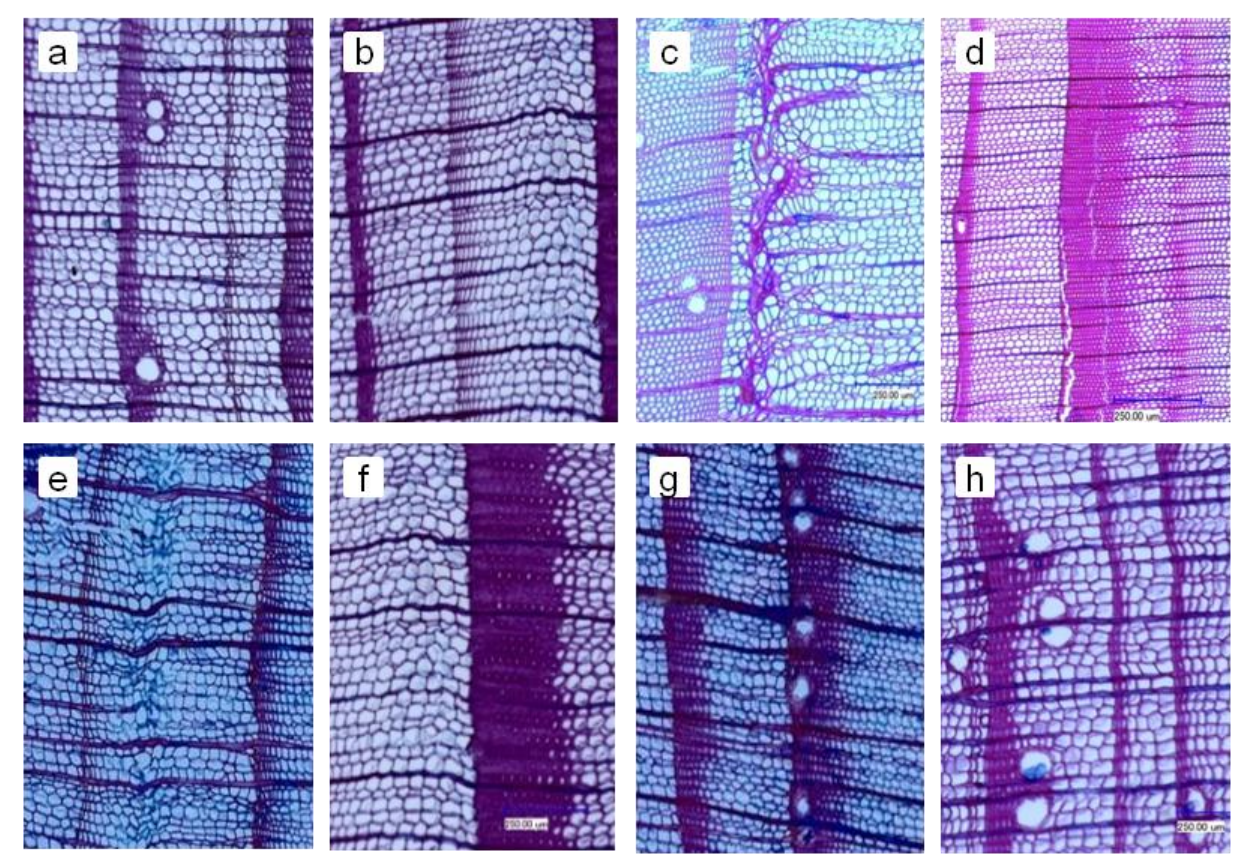

Fig.2.5. Examples of intra-annual wood-anatomical features in the wood of Larix sibirica from Mt. Bogd Uul: (a) narrow latewood, (b) light latewood, (c) frost ring, (d) density fluctuations, (e) collapsed cells, (f) dark latewood, (g) resin ducts in earlywood, (h) resin ducts in latewood.

Table 2.4. Percentage of intra-annual wood-anatomical features of the analyzed tree-rings in old and middle-aged larch trees from the forest interior and the forest edge.

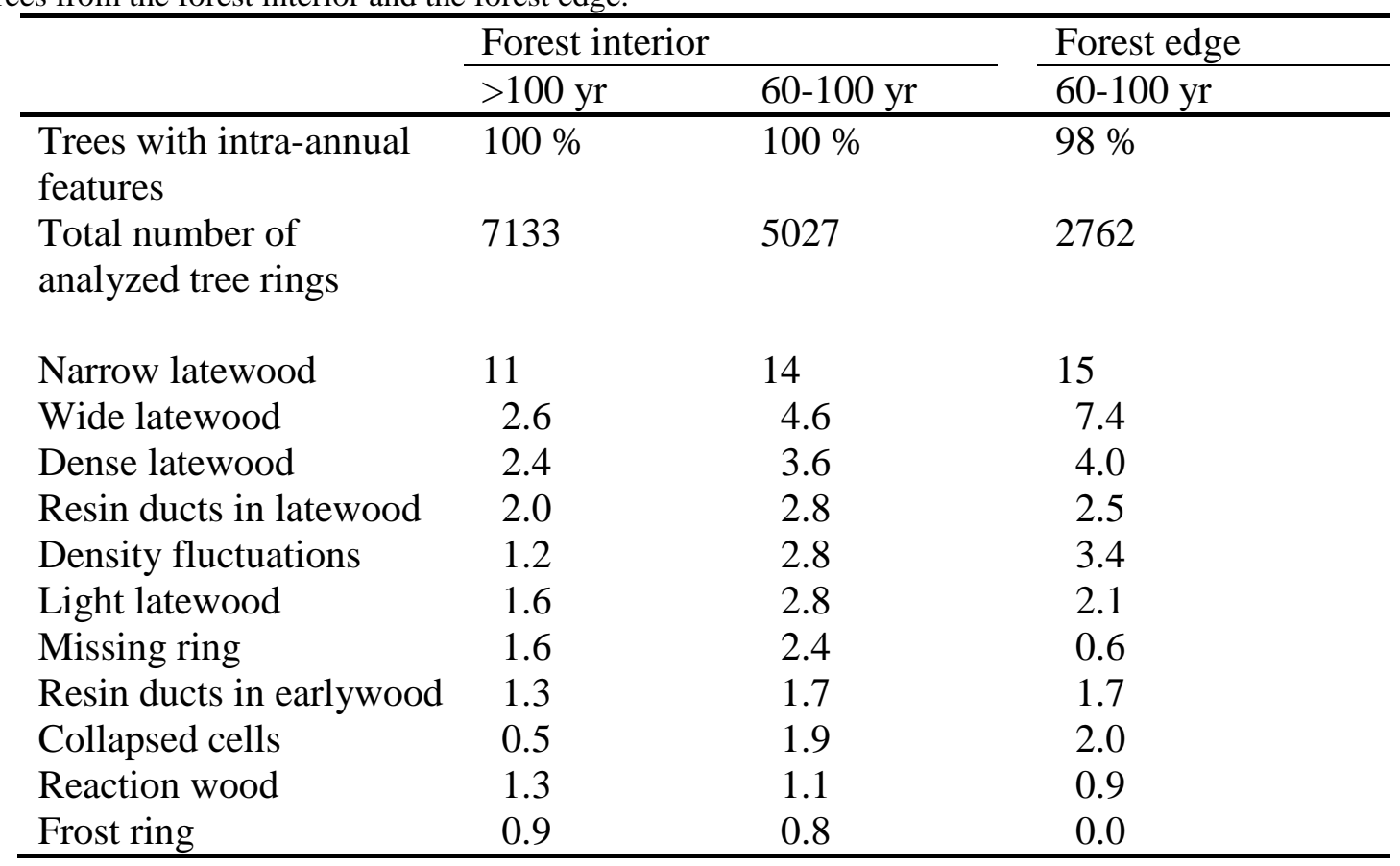


Recently (period 1997-2007), the frequency of intra-annual wood-anatomical features has increased (Fig. 2.6). Analysis of time-dependent changes in individual wood-anatomical features for the interval from 1957-2007 showed an increase in narrow latewood frequency (Fig. 2.7a-c). This increase was observed both in the forest interior and the forest edge as well as in old and middle-aged trees; it was thus not dependent on tree age. In the multiple regression analysis, the occurrence of narrow latewood was correlated with elevated temperatures in June and July (daily mean $>15{ }^{\circ} \mathrm{C}$ ) and periods of low precipitation in June (Table 2.5). In contrast to narrow latewood, the frequency of wide latewood has remained unchanged (Fig. 2.7a-c); in the periods from 19771991 and since 1998, wide latewood did not occur. Trees in the forest interior tended to form more often wide latewood than trees at the forest edge; patterns were independent of tree age. The formation of wide latewood was correlated with low May temperatures, a low number of hot days (daily mean $>15^{\circ} \mathrm{C}$ ) in June and the scarcity of drought periods $>5$ consecutive days in April or August, respectively (Table 2.5).

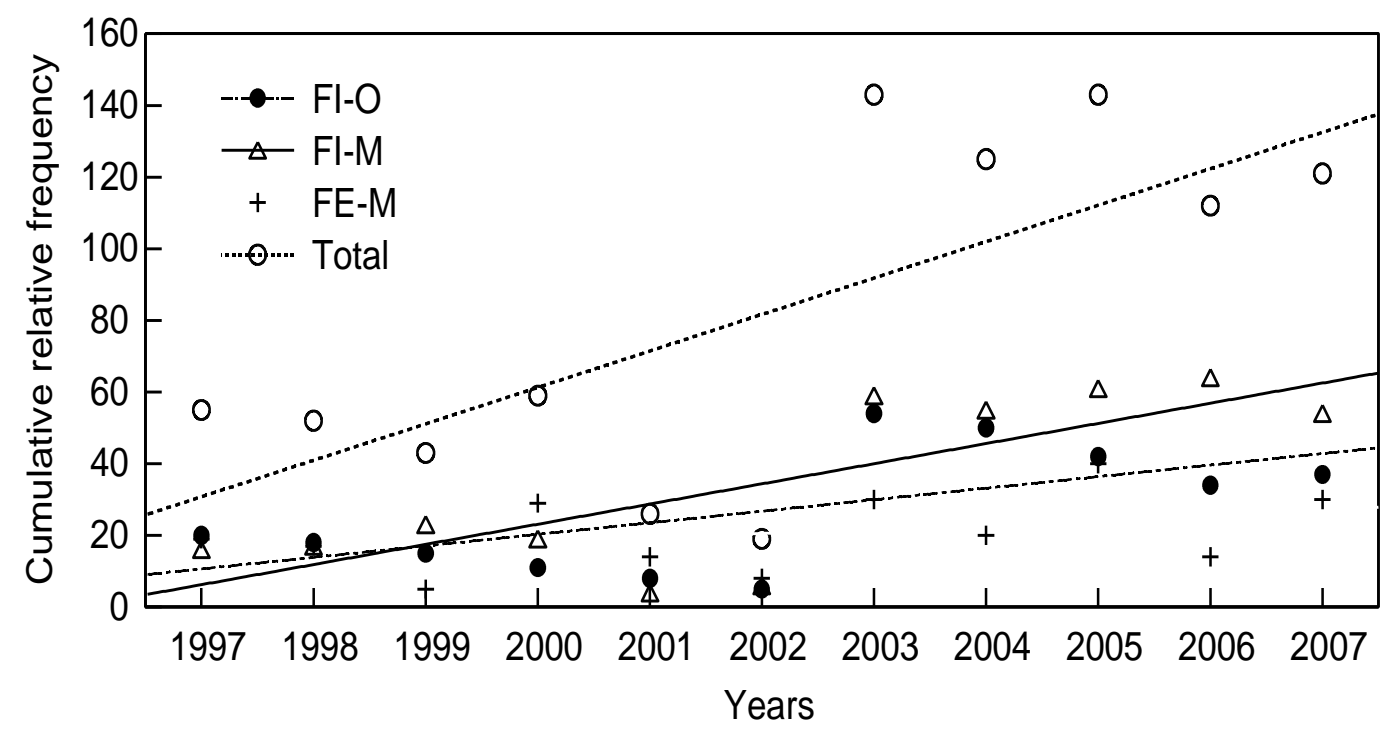

Fig. 2.6. Number of intra-annual wood-anatomical features in trees from the forest interior (FI-O, old trees; FI-M, middle-aged trees), from the forest edge (FE-M, middle-aged trees), and all trees. Linear regression results: FI-O, $\mathrm{r}=0.61, P<0.05$; FI-M, r=0.77, $P<0.01$; Total, $\mathrm{r}=0.71, P<0.01$. 
Table 2.5. Results of multiple regression analyses for explaining the stabilized frequency of intra-annual woodanatomical features in the middle-aged trees from the forest interior (FI) and the forest edge (FE) by temperature and precipitation parameters. ${ }^{\mathrm{a}}$

\begin{tabular}{lllll}
\hline & Habitat & $\mathrm{R}^{2}$ & $P$ & Model $^{\mathrm{b}}$ \\
\hline Narrow latewood & FI & 0.34 & 0.002 & T15JUN, TAJUN (-), P15JUN \\
& FE & 0.46 & $<0.001$ & T15JUN, T15JUL, TAJUN (-) \\
Wide latewood & FI & 0.31 & 0.01 & T-5MAY, T15JUN (-), TAJUN, P5AUG (-) \\
& FE & 0.27 & 0.01 & T-5MAY, T15JUN (-), P5APR (-) \\
Dense latewood & FI & 0.35 & 0.002 & T15AUG (-), TAAPR (-), P5JUN \\
& FE & 0.46 & $<0.001$ & TAJUL (-), P5JUL, P5AUG \\
Resin ducts in & FI & 0.25 & 0.02 & T15JUN, TAMAY, TAJUL (-) \\
latewood & FE & 0.17 & 0.09 & T-5APR, P5MAY (-), P5AUG (-) \\
Light latewood & FI & 0.24 & 0.04 & T0MAY, T-5MAY (-), T15AUG, TAAUG (-) \\
& FE & 0.33 & 0.008 & T0MAY, T-5MAY (-), T15AUG, TAAUG (-) \\
Missing ring & FI & 0.22 & 0.03 & T15JUN, TAJUN (-), P5AUG \\
& FE & 0.30 & 0.02 & T15JUN, TAJUN (-), TAJUL, P15MAY \\
Resin ducts in & FI & 0.28 & 0.02 & T15MAY, TAJUN (-), P5JUN (-), P15MAY (-) \\
earlywood & FE & 0.35 & 0.001 & T15MAY, P5AUG (-), P15MAY (-) \\
Collapsed cells & FI & 0.15 & 0.12 & T0MAY, T-5MAY (-), P5AUG (-) \\
& FE & 0.29 & 0.02 & T0MAY, T-5MAY (-), T15MAY (-), P5AUG (-) \\
\hline
\end{tabular}

\footnotetext{
${ }^{a}$ Analysis refers to the period from 1965-2007 due to the limited availability of climate data. Features which were only (frost rings) or primarily (density fluctuations) recorded in the tree rings formed prior to 1965 were omitted from the table.

${ }^{\mathrm{b}} \mathrm{T}-5$, days with mean temperature $<-5{ }^{\circ} \mathrm{C}$; $\mathrm{T} 0$, days with mean temperature $<0{ }^{\circ} \mathrm{C}$; T15, days with mean temperature $>15{ }^{\circ} \mathrm{C}$; TA, days with the daily mean temperature exceeding the long-term (1965-2007) mean temperature of the relevant month; P5, total number of continuous 5-day periods without precipitation; P15, total number of continuous 15-day periods without precipitation; (-), negative correlation (= negative beta value).
} 


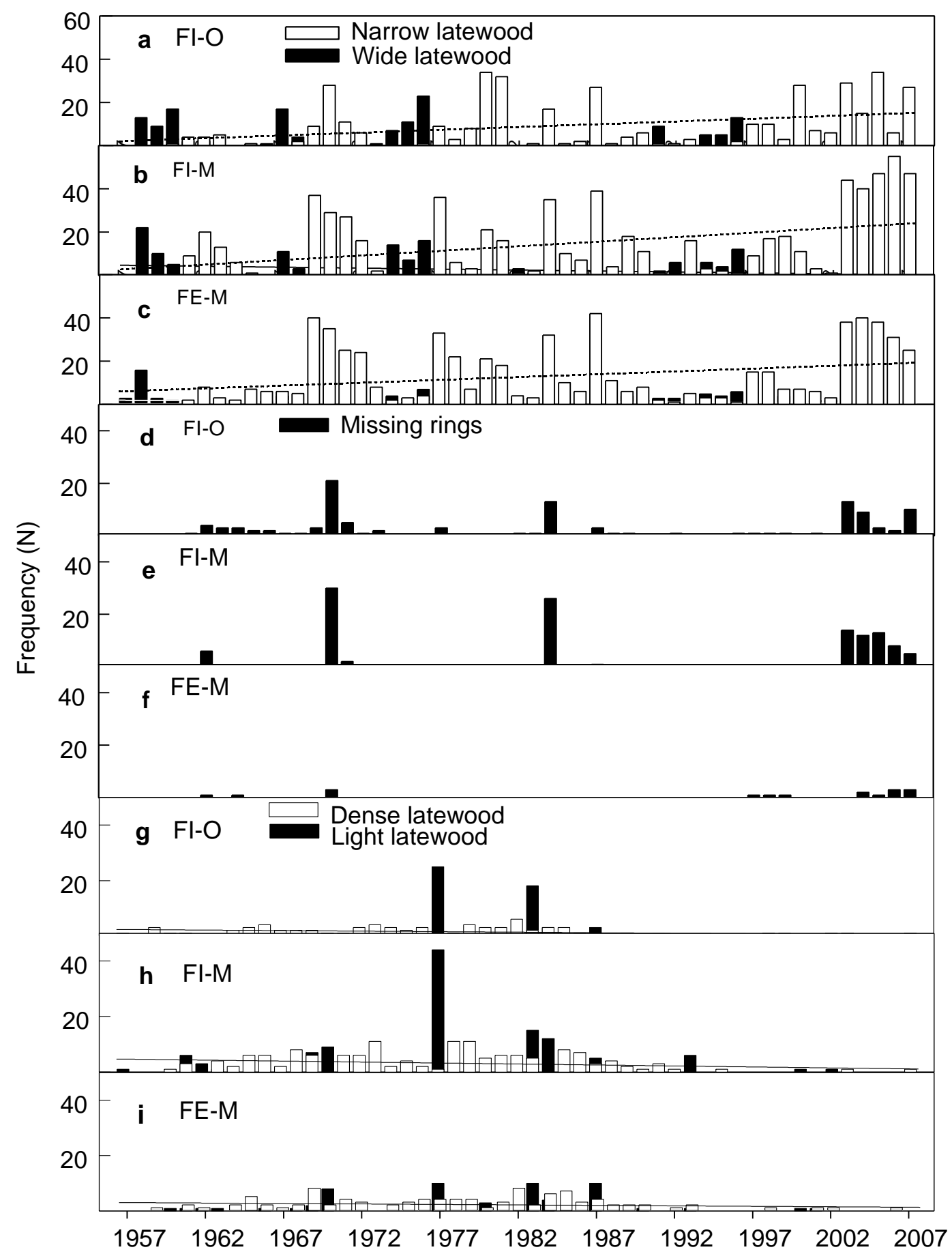

Fig. 2.7. Frequency of (a-c) narrow and wide latewood, (d-f) missing rings, (g-i) dense and light latewood in (a, d, g) old trees (FI-O) and (b, e, h) middle-aged larch trees (FI-M) from the forest interior as well as (c, f, i) middle-aged trees from the forest edge (FE-M). Linear regression results: narrow latewood, FI-O, $\mathrm{r}=0.29, P<0.01 ; \mathrm{FI}-\mathrm{M}, \mathrm{r}=0.40$, $P<0.01$; FE-M, r=0.36, $P<0.01$; dense latewood, FI-O, r=-0.38, $P<0.01$; FI-M, r=-0.32, $P<0.01$; FE-M, r=-0.24, $P<0.01$. 
The frequency of missing rings did not change between 1957 and 2007 (Fig. 2.7d-f). They occurred synchronously in old and middle age trees, but were less frequent at the edge than in the interior of the forests. However, missing rings were virtually absent between 1870 and 1960 (data not shown). The occurrence of missing rings was positively correlated with the frequency of hot days in June (daily mean $>15^{\circ} \mathrm{C}$ ) and drought periods during the growing season (Table 2.5).

Dense latewood has decreased in frequency from 1957-2010 (Fig. 2.7g-i). Frequencies and trends were very similar in middle-aged trees from the forest interior and the forest edge, but dense latewood was much rarer in old than middle-aged trees. Dense latewood frequency decreased with the frequency of hot summer days and increased with the number of short periods in summer without precipitation. The frequencies of resin ducts, reaction wood, density fluctuations, and collapsed cells (Supplemental Fig. 2.S1) did not show significant trends for increase or decrease between 1957 and 2007. Light latewood was often formed in years with frequent days with light frost in May (temperature $<0{ }^{\circ} \mathrm{C}$, but $>-5{ }^{\circ} \mathrm{C}$ ) and August temperatures $>15^{\circ} \mathrm{C}$. Light frost in May, combined with the scarcity of drought periods in late summer, was also typical for the formation of collapsed cells. 


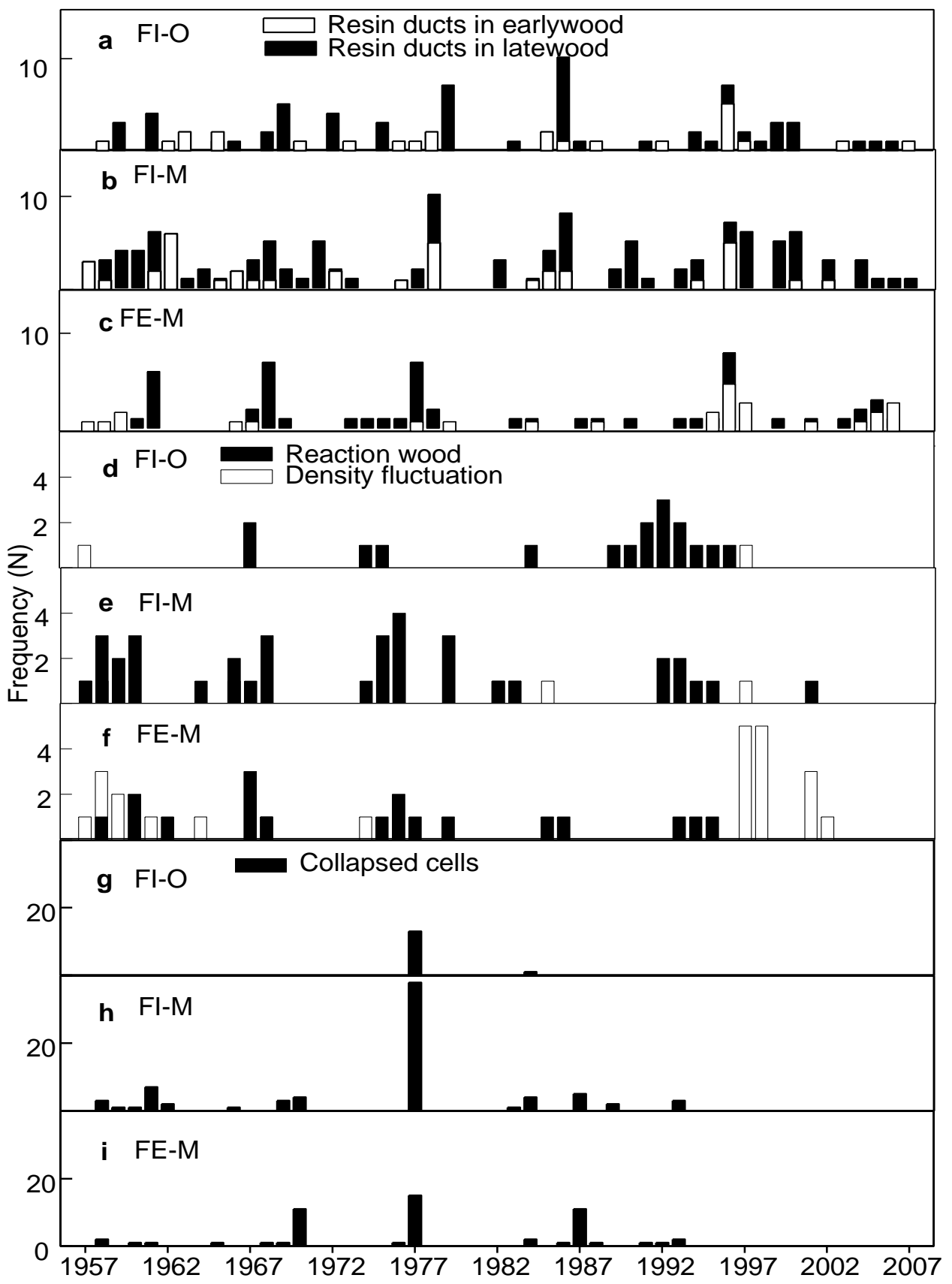

Supplemental Fig. 2.S1. Stabilized frequency of (a-c) density fluctuations and reaction wood, (d-f) resin ducts in earlywood and latewood, (g-i) dense and light latewood in (a, d, g) old trees (FI-O) and (b, e, h) middle-aged larch trees (FI-M) from the forest interior as well as (c, $\mathrm{f}, \mathrm{i})$ middle-aged trees from the forest edge (FE-M).

Frost rings were absent from tree rings formed since the 1950s (data not shown). However, they were frequent in the $19^{\text {th }}$ and the early $20^{\text {th }}$ centuries. In old trees frost rings were regularly found until the 1910 s and only occasionally afterwards, whereas middle-aged trees regularly formed frost rings between 1920 and 1940, suggesting the contribution of a tree age-related effect. 


\subsection{Discussion}

The present results suggest that increased aridity resulting from increased temperatures at constant precipitation has imprinted on the wood formation of L. sibirica in the forest-steppe ecotone of Mt. Bogd Uul. The correlation of tree-ring width with high precipitation and partly also low temperatures in summer clearly suggests that the forests in the study area are limited by summer drought. This agrees with other findings from the Mongolian forest-steppe ecotone obtained at elevations below 2000 m a.s.l. (Jacoby et al., 1999; Pederson et al., 2001; Dulamsuren et al., 2010b, 2011; De Grandpré et al., 2011), but contrasts with results from higher elevations of 2450 m a.s.l. in west-central Mongolia (Jacoby et al., 1996) and $2300 \mathrm{~m}$ a.s.l. in the Mongolian Altai Mountains (Dulamsuren et al., 2013) where the radial stem increment is primarily limited by low temperatures during the growing season. The limitation of wood formation by summer drought makes the forests on Mt. Bogd Uul susceptible to the increasing temperatures in that region (Fig. 2.2). Temporal variations in temperature and precipitation have led to shifts in the forest-steppe distribution in Mongolia throughout the Holocene (Gunin et al., 1999). The present increase in aridity at Mt. Bogd Uul might not be unprecedented within the last centuries (Pederson et al., 2013), but the predicted future increases in temperature certainly are beyond any increase at least after the medieval warm period (Sato et al., 2007). The higher mean sensitivity of the trees at the forest edge than in the forest interior is attributable to the lower intraspecific competition for water of the trees at the forest edge (Dulamsuren et al., 2009), which results in higher peak stem increment rates in favorable years as compared to trees from the forest interior (Fig. 2.3a).

The study of wood-anatomical features allows for a more precise analysis of climate warming effects on wood formation. The strong increase in the frequency of narrow latewood is doubtlessly the result of increased summer drought, as indicated by positive correlations with the frequency of days with the mean temperature exceeding $15^{\circ} \mathrm{C}$ in June and July and with drought periods from May to August. The results for the narrow latewood agree well with results of De Grandpré et al. (2011), who published a wood-anatomical study from Mongolia, where narrow latewood was increasingly found with decreasing late summer precipitation. The dominance of narrow latewood among the observations of wood-anatomical anomalies suggests that latewood responds more sensitively to the recent increase of aridity in the Mongolia forest-steppe than earlywood. This is explainable with the fact that the formation of earlywood is more dependent on 
the consumption of stored resources, while latewood formation is to a larger extent supported by photosynthetates from current assimilation (Rigling et al., 2001). Increased summer drought is also the putative cause of the absence of missing ring before 1960 and their regular formation afterwards. Missing ring formation is not much influenced by tree age, but by the canopy position (Lorimer et al., 1999). Thus, it is unlikely that the increased occurrence of missing rings in the past 50 years (in both old and middle-aged trees) is an effect dependent on tree age. The decline of dense latewood might be the result of less favorable growing seasons with ample water supply. However, since old trees formed dense latewood less often than middle-aged trees, an age-related effected might also be involved.

The lack of frost rings since the 1950s might indicate that the rising temperature itself also had an effect on wood formation, probably by reducing the severity of spring frosts. However, trees are known to become less susceptible to frost when the bark gets thicker with age (Gurskaya and Shiyatov, 2006). Therefore, ageing might have contributed to the the decline in frost rings.

The negative correlation of tree-ring width with December precipitation is surely not the result of a direct effect of snowfall, but results from the protective effective snow cover is exerting on hibernating herbivores. In Mongolia, this primarily refers to gypsy moth (Lymantria dispar L.), the eggs of which mostly overwinter in rock outcrops in the steppe near forest margins. Gypsy moth larvae infest trees at the forest edge more intensely than in the forest interior and cause growth reductions in the stemwood due to defoliation (Hauck et al., 2008; Dulamsuren et al., 2010c). This explains why the correlation between snowfall and tree-ring width was strongest in the trees from the forest edge. With respect to direct effects of climate on radial stem increment, gypsy moth infestations are likely to cause some distortion (Trotter et al., 2002), since both summer drought and gypsy moth attacks reduce tree-ring width (Dulamsuren et al., 2010c). However, as drought increases the susceptibility to herbivores (Mattson and Haack, 1987), this has the character of a positive feedback and does generally doubt the limitation of radial stem increment by dry summers. 


\subsection{Conclusions}

Our study from Mt. Bogd Uul in the Mongolian forest-steppe ecotone shows that increased summer drought is the key factor which has already reduced radial stem growth of L. sibirica in the past decades. This is line with published tree-ring studies from the Mongolian forest-steppe (Jacoby et al., 1999; Pederson et al., 2001; Dulamsuren et al., 2010b; De Grandpré et al., 2011). Furthermore, it agrees with the result of the wood-anatomical studies that the most significant changes in association with climate warming were observed in the latewood, which is mainly formed during summer, and with regard to the occurrene of missing rings.

\section{Acknowledgments}

Field work was funded by a grant of the German Science Foundation (Deutsche Forschungsmeinschaft, DFG) to Mrs. Dr. Ch. Dulamsuren (Du 1145/1-2). We are grateful to S. Nyambayar, D. Osokhjargal and L. Jadambaa (Ulan Bator) for their assistance in the field. Laboratory work and data evaluation was supported by grants of the German Academic Exchange Service (Deutscher Akademischer Austauschdienst, DAAD) to Mrs. M. Khishigjargal. B. Raufeisen (Göttingen) is thanked for drawing the map of the study area. 


\section{References}

Adiyasuren, Ts., 1997. Ecosystems of Bogd Khan Mountain. Ulaanbaatar Printing, Ulan Bator (in Mongolian).

Barkmann, U.B., 2000. Bogd-uul - der heilige Berg. Bemerkungen zu einem der ältesten Naturreservate der Welt. Mongolische Notizen 9, 45-48.

D'Arrigo, R.D., Jacoby, G.C., Pederson, N., Frank, D., Buckley, B., Baatarbileg, N., Mijiddorj, R., Dugarjav, Ch., 2000. Mongolian tree-rings, temperature sensitivity and reconstructions of Northern Hemisphere temperature. Holocene 10, 669-672.

D'Arrigo, R.D., Jacoby, G.C., Frank, D., Pederson, N., Cook, E., Buckley, B., Baatarbileg, N., Mijiddorj, R., Dugarjav, Ch., 2001a. 1738 years of Mongolian temperature variability inferred from tree-ring width chronology of Siberian pine. Geophysical Research Letters 28, 543-546.

D'Arrigo, R.D., Frank, D., Jacoby, G.C., Pederson, N., 2001b. Spatial response to major volcanic events in or about $\mathrm{AD}$ 536, 934 and 1258: frost rings and other dendrochronological evidence from Mongolia and northern Siberia: comment on R.B. Stothers, 'Volcanic dry fogs, climate cooling, and plague pandemics in Europe and the Middle East' (Climatic Change, 42, 1999). Climatic Change 49, 239-246.

Davi, N.K., Jacoby, G.C., Curtis, A.E., Baatarbileg, N., 2006. Extension of drought records for Central Asia using tree rings: west-central Mongolia. Journal of Climate 19, 288-299.

Davi, N.K., Jacoby, G.C., Fang, K., Li, J., D'Arrigo, R.D., Baatarbileg, N., Robinson, D., 2010. Reconstructing drought variability for Mongolia based on a large-scale tree ring network. Journal of Geophysical Research 115 (D22103), 1-9.

De Grandpré, L., Tardif, J.C., Hessı, A., Pederson, N., Conciatori F., Green, T.R., Oyunsanaa, B., Baatarbileg, N., 2011. Seasonal shift in the climate responses of Pinus sibirica, Pinus sylvestris, and Larix sibirica trees from semi-arid, north central Mongolia. Canadian Journal of Forest Research 41, 1242-1255.

Dulamsuren, Ch., Hauck, M., Bader, M., Osokhjargal, D., Oyungerel, Sh., Nyambayar, S., Runge, M., Leuschner, C., 2009. Water relations and photosynthetic performance in Larix sibirica growing in the forest-steppe ecotone of northern Mongolia. Tree Physiology 29, 99-110. 
Dulamsuren, Ch., Hauck, M., Khishigjargal, M., Leuschner, H.H., Leuschner, C., 2010a. Diverging climate trends in Mongolian taiga forests influence growth and regeneration of Larix sibirica. Oecologia 163, 1091-1102.

Dulamsuren, Ch., Hauck, M., Leuschner, C., 2010b. Recent drought stress leads to growth reductions in Larix sibirica in the western Khentey, Mongolia. Global Change Biology 16, 3024-3035.

Dulamsuren, Ch., Hauck, M., Leuschner, H.H., Leuschner C., 2010c. Gypsy moth-induced growth decline of Larix sibirica in a forest-steppe ecotone. Dendrochronologia 28, 207-213.

Dulamsuren, Ch., Hauck, M., Leuschner, H.H., Leuschner, C., 2011. Climate response of tree-ring width in Larix sibirica growing in the drought-stressed forest-steppe ecotone of northern Mongolia. Annals of Forest Science 68, 275-282.

Dulamsuren, Ch., Khishigjargal, M., Leuschner, C. , Hauck, M., 2013. Response of tree-ring width to climate warming and selective logging in larch forests of the Mongolian Altai. Journal of Plant Ecology, doi: 10.1093/jpe/rtt019.

Eckstein, D., Bauch, J., 1969. Beitrag zur Rationalisierung eines dendrochronologischen Verfahrens und zur Analyse seiner Aussagesicherheit. Forstwissenschaftliches Centralblatt $88,230-250$.

Fritts, H.C., 1976. Tree rings and climate. Academic Press, London.

Gunin, P.D., Vostokova, E.A., Dorofeyuk, N.I., Tarasov, P.E., Black, C.C., 1999. Vegetation dynamics of Mongolia. Kluwer, Dordrecht.

Gurskaya, M.A., Shiyatov, S.G., 2006. Distribution of frost injuries in the wood of conifers. Russian Journal of Ecology 37, 7-12.

Hauck, M., Dulamsuren, Ch., Heimes, C., 2008. Effects of a gypsy moth invasion on the performance of Larix sibirica in a forest-steppe ecotone of northern Mongolia. Environmental and Experimental Botany 62, 351-356.

Hessl, A.E., Uyanga, A., Brown, P., Oyunsannaa, B., Green, T., Jacoby G.C., Sutherland, E.K., Baatarbileg, N., Maxwell, R.S., Pederson N., De Grandpré, L., Saladyga, T., Tardif, J.C., 2012. Reconstructing fire history in central Mongolia from tree-rings. International Journal of Wildland Fire 21, 86-92. 
Hilbig, W., Jäger, E.J., Knapp, H.D., 2004. Die Vegetation des Bogd-uul bei Ulaanbaatar (Mongolei) - Standortsbindung und pflanzengeographische Stellung. Feddes Repertorium $115,265-342$.

Jacoby, G.C., D'Arrigo, R.D., Davaajamts, T., 1996. Mongolian tree-rings and $20^{\text {th }}$-century warming. Science 273, 771-773.

Jacoby, G.C., D'Arrigo, R.D., Pederson, N., Buckley, B., Dugarjav, Ch., Mijiddorj, R., 1999. Temperature and precipitation in Mongolia based on dendroclimatic investigations. IAWA J 20, 339-350.

Körner, C., Sarris, D., Christodoukalis, D., 2005. Long-term increase in climatic dryness in the East-Mediterranean evidenced for the island of Samos. Regional Environmental Change 5, 27-36.

Leuschner, H, H., Schweingruber, F, H., 1996. Dendroökologishe Klassifizierung und Auswertung häufig aufredender intraannueller holzanatomisher Merkmale bei Eichen und Kiefern. Dendrochronologia 14, 275-285.

Lkhagvadorj, D., Hauck, M., Dulamsuren, Ch., Tsogtbaatar, J., 2013. Pastoral nomadism in the forest-steppe of the Mongolian Altai under a changing economy and a warming climate. Journal of Arid Environments 88, 82-89.

Lorimer, C.G., Dahir, S.E., Singer, M.T., 1999. Frequency of partial and missing rings in Acer saccharum in relation to canopy position. Plant Ecology 143, 189-202.

Mattson, W., Haack, R., 1987. Role of drought in outbreaks of plant-eating insects. Bioscience 37, 110-118.

Meyer, F.D., 1999. Pointer year analysis in dendroecology: a comparison of methods. Dendrochronologia 16-17, 193-204.

Pederson, N., Jacoby, G.C., D'Arrigo, R.D., Cook, E.R., Buckley, B., Dugarjav, C., Mijiddorj, R., 2001. Hydrometeorological reconstructions for northeastern Mongolia derived from treerings: 1651-1995. Journal of Climate 14, 872-881.

Pederson, N., Leland, C., Baatarbileg, N., Hessl, A.E., Bell, A.R., Martin-Benito, D., Saladyga, T., Suran, B., Brown, P.M., Davi, N.K., 2013. Three centuries of shifting hydroclimatic regimes across the Mongolian Breadbasket. Agricultural and Forest Meteorology, in press. 
Rigling, A., Waldner, P, O., Forster, T., Bräker, O.U., Pouttu, A., 2001. Ecological interpretation of tree-ring width and intrannual density fluctuations in Pinus sylvestris on dry sites in the central Alps and Siberia. Canadian Journal of Forest Research 31, 18-31.

Sankey, T.T., Montagne, C., Graumlich, L., Lawrence, R., Nielsen, J., 2006. Lower forestgrassland ecotones and 20th century livestock herbivory effects in northern Mongolia. Forest Ecology and Management 233, 36-44.

Sato, T., Kimura, F., Kitoh, A., 2007. Projection of global warming onto regional precipitation over Mongolia using a regional climate model. Journal of Hydrology 333, 144-154.

Schweingruber, F.H., 1988. Tree rings. Basics and applications of dendrochronology. Kluwer, Dordrecht.

Trotter, R.T., Cobb, N.S., Whitham, T.G., 2002. Herbivory, plant resistance, and climate in the tree ring record: interactions distort climatic reconstructions. Proceeding of the National Academy of the United States of America 99, 10197-10202.

Tsogtbaatar, J., 2004. Deforestation and reforestation needs in Mongolia. Forest Ecology and Management 201, 57-63. 


\section{CHAPTER}

3

\section{RESPONSE OF TREE-RING WIDTH TO CLIMATE WARMING AND SELECTIVE LOGGING IN LARCH FORESTS OF THE MONGOLIAN ALTAI}

Choimaa Dulamsuren, Mookhor Khishigjargal, Christoph Leuschner and Markus Hauck

Published in Journal of Plant Ecology 


\begin{abstract}
Aims

The Mongolian Altai is an old settlement area, which is populated by pastoral nomads since 20003000 years. Forests in this region (at ca. $2300 \mathrm{~m}$ a.s.1.) are highly fragmented and border on steppe and alpine grasslands, which are used for mobile livestock husbandry. The climate in Central Asia is warming to levels clearly above the global average, which affects the vegetation. Furthermore, the transition from planned to market economy and the decollectivization of livestock 20 years ago has strongly changed land use practices in Mongolia, especially resulting in an increase in recent logging activities. We were interested in the question how climate warming and selective logging influence the annual stem growth and the stand structure.
\end{abstract}

\title{
Methods
}

The impact of climate and land use by the pastoral nomads on the annual stem increment of more than 1800 trees of Siberian larch (Larix sibirica) was analyzed. Different groups of trees with divergent growth trends depending on the social position and stand history were identified by nonmetric multidimensional scaling and analysis of similarities. Long-term trends in the annual stem increment were analyzed by establishing separate regional growth curves for trees of different age classes.

\section{Important Findings}

Instrumental climate data substantiate an increase of temperature by $2.1^{\circ} \mathrm{C}$ since 1940 at constant precipitation. Trees benefit from the increased temperatures. Climate-response analysis revealed that radial stem increment was promoted by the temperature in early summer, but also high precipitation in spring and in the year before tree-ring formation. Forest dynamics is also strongly influenced by anthropogenic activities. In addition to the natural forest dynamics, logging resulted in divergent growth trends within given age classes and habitats (forest interior and forest edge); overall, 22 groups of trees with different characteristics in the annual radial stem increment were identified. A tree-ring series-based reconstruction of logging intensity since 1935 suggests that moderate selective logging occurred throughout the study period. However, selective logging was strongly intensified after 1990 as the result of the breakdown of the Communist regime in 
Mongolia and the transition from centrally planned to market economy. Because tree stump densities showed that the ratio of felled to live trees was $2: 1$ in the interior or even $0.9: 1$ at the edges of the forests and most logging occurred during the past 20 years, it must be concluded that the forests of the Mongolian Altai are presently exploited far beyond the level of sustainability. A close correlation of the ratio of felled to live trees with the density of summer camps of pastoral nomads in the vicinity suggests that trees are primarily felled by the local population.

Keywords: climate change, forest management, forest-steppe ecotones, Central Asia, Larix sibirica 


\subsection{Introduction}

Forest trees in Central Asia's forest-steppe ecotones live their lives on the edge, as they are exposed to an extreme climate with water shortages during the growing season and low temperatures in winter. Low temperatures limit the tree growth at high elevations and control the position of alpine treelines (Jacoby et al., 1996). As for precipitation, trees have to cope with a considerable interannual variability (Davi et al., 2010; Fang et al. 2010; Yatagai and Yasunari 1995) which stresses them during drought periods (Dulamsuren et al., 2009). Thus, the drought tolerance of many trees in Central Asia is regularly driven to the limit. This entails that they are susceptible to any change in the climatic conditions that deteriorates the water supply or increases the water consumption by increased evaporative demand of the atmosphere. This explains the repeated northward or southward migrations of the taiga forest biomes in Central Asia's foreststeppe ecotones with oscillations of climate during different periods of the Holocene (Gunin et al., 1999; Tarasov et al., 2006, 2007). The recent responses of Central Asian forests to changes in climate are highly variable because the increase in temperature in the scope of global warming and even more trends for precipitation varies between regions. Li et al. (2009) classified Mongolia as an area of stable moisture between 1951 and 2005 and northwestern China, including Xinjiang, and the Tibetan Plateau as an area of increased moisture during the same period. These, however, are rather global assessments. Batima et al. (2005) and Dulamsuren et al. (2010a) emphasized that the precipitation trends in Mongolia show a strong spatial variability, sometimes with contrasting trends even across distances of only a few hundred kilometers. Depending on the regional climate trend, the growth and regeneration of trees are promoted by climate warming in areas with favorable moisture conditions (D'Arrigo et al., 2000; Dulamsuren et al., 2010a), but sharply reduced in regions with increasing frequency and severity of drought events during the growing season (Allen et al., 2010; Dulamsuren et al., 2010b). The high spatial heterogeneity of moisture trends in Mongolia and other areas of Central Asia demands for the study of regional tree growth responses to climate variation.

The Mongolian Altai is a high-elevation landscape mosaic of coniferous forest, steppe and alpine tundra. Forests that are dominated by Siberian larch (Larix sibirica Ledeb.) are remnants of more widespread forests in the Middle Holocene. Since that time, the forested area has strongly declined due to reduced precipitation (Rudaya et al., 2008). Today, forests usually occur in 
relatively small patches on north facing slopes where they are usually restricted to the middle part. The footslopes and adjacent valleys are dominated by steppe that is inhabited by pastoral nomads and their livestock; sporadically occurring larch trees in the river valleys suggest a considerable anthropo-zoogenic influence on the present position of the lower forest line. The Altai was colonized by humans in the Paleolithic and the presently prevailing lifestyle of pastoral nomadism was probably adopted 2000-3000 years ago (Rudaya et al., 2008; Schlütz and Lehmkuhl, 2007). Even forests and alpine meadows above the upper treeline are regularly grazed by livestock, albeit less intensely than the valleys.

Forests in forest-steppe ecotones are usually highly fragmented. In addition to climate, they are subject to land use, mostly not in the form of systematic forestry, but as unplanned activities of the local population. These activities include selective logging, collection of fuelwood, forest grazing, the collection of edibles like mushrooms and berries, and hunting (Lkhagvadorj et al., 2013). In Mongolia and the countries of the former Soviet Union, the political and economic frameworks that officially and unofficially regulates land use has strongly changed due to the transition from planned economy during Communist times to the present market economy. This primarily concerns the decollectivization of agriculture, unemployment and the sometimes reduced willingness of the population to obey rules and laws (Griffin, 1995; Sneath, 2004). At many places, these changes were the cause of increased (often illegal) timber harvest (Erdenechuluun, 2006; Kushlin et al., 2004).

Changes in climate and land use by pastoralists have influenced the forests of the Mongolian Altai already for millennia. This study was conducted to analyze the impact of the rapid changes that recently have become effective with regard to climate (late 20th century warming) and land use (as a result of the political and economic transformation process). Our target parameter was tree-ring width in stems of larch trees, which is suited to detect climate signals and rapid changes in stand density as caused by selective logging. The objectives of our study included to analyze recent trends in temperature and precipitation as well as in the radial stem increment. With our study, we aimed at testing the hypothesis that climate warming has exerted a beneficial effect on the annual stem increment in the cold high-elevation environment of the Mongolian Altai, whereas the increment was increasingly influenced by selective logging in the past decades. 


\subsection{Material and methods}

\subsubsection{Study area}

Field work was carried out in the Mongolian Altai in the Altai Tavan Bogd National Park in the Dayan administrative subunit ('bag') of the province ('aimag') of Bayan-Ulgii, western Mongolia, $110 \mathrm{~km}$ southwest of the city of Ulgii (Lkhagvadorj et al., 2013). The vegetation of the study area is dominated by alpine meadows, relatively moist true steppe and dry mountain steppe. Forests occur on north-facing slopes between an elevation of ca. 2000 and $2500 \mathrm{~m}$ a.s.1. in contact with true steppes and alpine meadows. Forests usually grow only on the upper, or if an alpine treeline is present, on the central parts of the mountain slopes. The lack of forests on the slope base is assumed to be the result of the long-standing human influence in the Altai Mountains. The flanks of the central chain of high peaks of the Mongolian Altai (up to $4734 \mathrm{~m}$ a.s.1.) are also covered by forests at their base. Most forests are only formed by Siberian larch, whereas Siberian spruce (Picea obovata Ledeb.) and Siberian cedar (Pinus sibirica Du Tour) rarely contribute to the forest assemblages at the foot of the high peaks (Beket, 2009). Geologically, the Mongolian Altai is dominated by siliceous rock, including granite and schist. The prevailing forest soils are Leptosols. The study area is located in the zone of continuous permafrost (Sharkhuu and Sharkhuu, 2012).

\subsubsection{Sample plots}

Field work was carried out in July 2010. Six forested sites were selected on the northern flank of a mountain ridge located $2-7 \mathrm{~km}$ south and south south east of Lake Dayan Nuur $\left(48^{\circ} 23^{\prime} \mathrm{N}, 88^{\circ} 55^{\prime}\right.$ E). The geographical position and elevation of these sites are compiled in Table 3.1. The distance between neighboring sites amounted to $2.2 \pm 0.5 \mathrm{~km}$. Site selection was a non-random procedure, but included all available forest islands on the studied mountain range; thus, the selection procedure largely excluded the subjective choice of sites. Relatively moist depressions that occur locally on the mountain slopes were deliberately avoided to improve the comparability between the sites. At each site, four plots each of $20 \mathrm{~m}$ x $20 \mathrm{~m}$ size were selected. One of them was located at the forest edge with the lower boundary of the plot being identical with the forest line to the 
steppe. The three other plots were located at 50 to $100 \mathrm{~m}$ distance from the edge in direction of the forest interior. The distance of the three interior plots from one another was ca. $20 \mathrm{~m}$; these three plots were statistically not independent and should provide a broader basis for the data from the forest interior. In addition to the trees on the sample plots, 99 additional trees were sampled in the vicinity of the plots in the $>160$ year age class to boost replication (Table 3.1). For the analysis of potential effects of the human population density on logging intensity, the total number of summer camps of pastoral nomads in a distance within $1 \mathrm{~km}$ from the sample plots was surveyed by determining the geographical coordinates of the individual camps; the distance from the sample plots consistently refers to the forest edge plots. This mapping was done once during the mid of the growing season; the nomads in the study area do not move much during the growing season, and there is little interannual variation in the moving habits (Lkhagvadorj et al., 2013).

\subsubsection{Analysis of climate trends from weather data}

Climate data used in this study were available from the village of Altai (station 'Yalalt', 48 $17^{\prime} \mathrm{N}$, 89³1' E, $2150 \mathrm{~m}$ a.s.1.), $40 \mathrm{~km}$ east of Lake Dayan Nuur, since 1970. Temperature was reconstructed for a longer interval (namely since 1940) with the help of data from the weather station at Ulgii City (1960 m a.s.1.). This was done by means of linear regression analysis using the equation $y=0.997 x-3.89$, which resulted from correlating the monthly temperature data from Altai with those from Ulgii City across all months $(\mathrm{r}=0.995, P<0.001)$. The calculated versus the recorded temperature data are displayed in Fig. 3.1a. Reconstructing precipitation data the same way turned out to be less reliable, considering inter-annual variation, whereas the long-term trend is rather well estimated $(y=0.65 x+3.54, \mathrm{r}=0.79, P<0.001)$. Comparison of calculated and recorded data shows that years with extremely low and high precipitation are not sufficiently detected with the reconstruction (Fig. 3.1b). Therefore, the calculated precipitation data were not used for climate-response analysis of tree-ring width, but merely for reconstructing the trend for the annual totals of precipitation, whereas relationships of tree-ring width with climate were analyzed with the instrumental data from Altai. Temperature in Dayan is overestimated by ca. $1^{\circ} \mathrm{C}$ and precipitation is underestimated relative to the weather data from Altai, as the elevation of this 
weather station is ca. $150 \mathrm{~m}$ below that of Dayan. Furthermore, Altai is located in the lee of a mountain ridge, which rises east of Dayan.

\subsubsection{Field and laboratory work for tree-ring analysis}

On the total of 24 plots, all larch trees with a stem diameter of at least $3 \mathrm{~cm}$ were included in wood-core sampling for tree-ring analysis. This way, a total of 1826 trees was sampled (Table 3.1). If conspicuously older trees were available outside the plots, they were additionally sampled as reference samples to establish long tree-ring chronologies, but not included in plot-related calculations. The total of such additionally sampled trees was 114 ; the total numbers of these trees are given in brackets in Table 3.1. Wood cores were collected at this height using an increment borer of $5 \mathrm{~mm}$ inner diameter. The borer was driven into the wood parallel to the contour lines of the mountain slopes to avoid compression wood. Additional data, including trunk diameter, dominance type (dominant, subdominant and suppressed) and intraspecific competition (close neighbors [at $<1 \mathrm{~m}$ distance], intermediate distance to nearest neighbor [ca. 1-2m], relatively large gap to neighboring trees [ $>2 \mathrm{~m}]$, were recorded in the field. Furthermore, the total number of tree stumps was counted on every plot to assess the extent of recent logging activities. Annual tree-ring width was measured with a precision of $10 \mu \mathrm{m}$ on a movable object table (Lintab 6, Rinntech, Heidelberg, Germany), the movements of which are electronically transmitted to a computer system equipped with TSAP (Time Series Analysis and Presentation)-Win software (Rinntech).

\subsubsection{Evaluation of tree-ring data}

Evaluation of tree-ring data was, like data recording, conducted with TSAP-Win software. Four age classes (Table 1) were distinguished in the analyses including 'very old trees' which included all trees older than 160 years, 'old trees' (101 - 160 years old), 'middle-aged trees' (60 - 100 years old) and 'young trees' ( $<60$ years old). Age is generally specified as the age of the oldest tree ring ('cambial age') at the sampling height of $1.3 \mathrm{~m}$; ca. 10 (at most 20) years should be added to deduce tree age from these age specifications (Körner et al., 2005; Sankey et al., 2006). In the case 
of the >160-year old trees, age was partly underestimated by our methods, because in $13 \%$ of these trees the core was rotten and incomplete. Nevertheless, we preferred to include these incomplete cores, because we did not perform any extensive interpretation on the absolute age of the very old trees.

Table 3.1. Age structure of the sampled Larix sibirica trees with sample size $(N)$ and mean cambial age for the individual study sites.

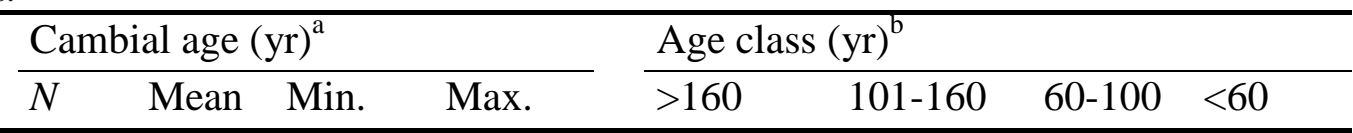

\begin{tabular}{|c|c|c|c|c|c|c|c|c|}
\hline \multicolumn{9}{|c|}{ Site $1\left(48^{\circ} 14^{\prime} 39^{\prime \prime} \mathrm{N}, 88^{\circ} 57^{\prime} 0 " \mathrm{E}, 2375 \mathrm{~m} \text { a.s.l, } N=220+27 \text { trees }\right)^{\mathrm{c}}$} \\
\hline FI 1 & 68 & 65 & 26 & 270 & $8(16)$ & 2 & 6 & 52 \\
\hline FI 2 & 67 & 76 & 56 & 101 & 0 & 1 & 62 & 4 \\
\hline FI 3 & 21 & 73 & 59 & 95 & 0 & 0 & 19 & 2 \\
\hline FE & 64 & 64 & 41 & 77 & $0(11)$ & 0 & 37 & 27 \\
\hline \multicolumn{9}{|c|}{ Site $2\left(48^{\circ} 15^{\prime} 16^{\prime \prime} \mathrm{N}, 88^{\circ} 54^{\prime} 25^{\prime \prime}\right.$ E, $2335 \mathrm{~m}$ a.s.l, $N=278$ trees $)$} \\
\hline FI 1 & 46 & 70 & 27 & 150 & 0 & 13 & 1 & 32 \\
\hline FI 2 & 69 & 64 & 24 & 259 & 1 & 13 & 5 & 50 \\
\hline FI 3 & 83 & 64 & 22 & 254 & 7 & 7 & 14 & 55 \\
\hline FE & 80 & 67 & 40 & 225 & 1 & 0 & 61 & 18 \\
\hline \multicolumn{9}{|c|}{ Site $3\left(48^{\circ} 15^{\prime} 35^{\prime \prime} \mathrm{N}, 88^{\circ} 54^{\prime} 11^{\prime \prime}\right.$ E, $2300 \mathrm{~m}$ a.s.l, $N=303$ trees) } \\
\hline FI 1 & 82 & 100 & 39 & 434 & 8 & 16 & 41 & 17 \\
\hline FI 2 & 113 & 74 & 40 & 307 & 3 & 9 & 55 & 46 \\
\hline FI 3 & 62 & 102 & 42 & 435 & 5 & 22 & 19 & 16 \\
\hline $\mathrm{FE}$ & 46 & 68 & 54 & 76 & 0 & 0 & 41 & 5 \\
\hline \multicolumn{9}{|c|}{ Site $4\left(48^{\circ} 16^{\prime} 3^{\prime \prime} \mathrm{N}, 88^{\circ} 51^{\prime} 35^{\prime \prime} \mathrm{E}, 2320 \mathrm{~m}\right.$ a.s.l, $N=324+34$ trees $)$} \\
\hline FI 1 & 87 & 104 & 39 & 288 & $10(14)$ & 31 & 21 & 25 \\
\hline FI 2 & 78 & 100 & 36 & 281 & 9 & 17 & 23 & 29 \\
\hline FI 3 & 80 & 56 & 31 & 230 & 7 & 0 & 0 & 73 \\
\hline FE & 79 & 74 & 32 & 268 & $7(10)$ & $4(2)$ & $29(8)$ & 39 \\
\hline \multicolumn{9}{|c|}{ Site $5\left(48^{\circ} 15^{\prime} 12^{\prime \prime} \mathrm{N}, 88^{\circ} 50^{\prime} 17^{\prime \prime}\right.$ E, $2375 \mathrm{~m}$ a.s.l, $N=322+25$ trees) } \\
\hline FI 1 & 84 & 100 & 30 & 340 & $13(10)$ & 3 & 60 & 8 \\
\hline FI 2 & 104 & 95 & 49 & 348 & 7 & 0 & 95 & 2 \\
\hline FI 3 & 57 & 69 & 27 & 153 & 0 & 12 & 20 & 25 \\
\hline $\mathrm{FE}$ & 77 & 70 & 38 & 314 & $2(15)$ & 1 & 49 (1) & 25 \\
\hline \multicolumn{9}{|c|}{ Site $6\left(48^{\circ} 14^{\prime} 59^{\prime \prime} \mathrm{N}, 88^{\circ} 55^{\prime} 57^{\prime \prime}\right.$ E, 2305 m a.s.l, $N=379+28$ trees) } \\
\hline FI 1 & 130 & 73 & 36 & 322 & $7(15)$ & 0 & 70 & 53 \\
\hline FI 2 & 95 & 36 & 318 & 47 & 15 & 3 & 30 & 47 \\
\hline FI 3 & 118 & 79 & 32 & 276 & 8 & 3 & 73 & 34 \\
\hline $\mathrm{FE}$ & 36 & 63 & 30 & 280 & $2(8)$ & 0 & $30(5)$ & 4 \\
\hline
\end{tabular}

${ }^{a}$ Additional trees sampled outside the sample plot are excluded from the age statistics

${ }^{\mathrm{b}}$ Number of trees additionally sampled outside the plots are given in brackets

${ }^{\mathrm{c}}$ Sites with total number of sample trees (plus additional trees sampled outside the plots. Geographical coordinates and altitude refer to the sample plot at the forest edge. Plots: FE, forest edge; FI, forest interior with replicate 1-3. 
Tree-ring series were controlled for missing rings and false rings during crossdating because especially missing tree rings can be relatively common in the semiarid environment of Mongolia at the drought limit of forests. In the 60-year period from 1951 to 2010, the frequency of missing rings (in percentage of the total tree rings) in our samples was $1.0 \%$ (forest edge: $0.2 \%$ ) in >160year old trees, $0.9 \%(0.0 \%)$ in 101- to 160-year old trees, $2.6 \%$ (1.2\%) in 60- to100-year old trees and $0.6 \%(1.0 \%)$ in <60-year old trees. Trees were pooled separately for the forest interior (but across the three interior plots of each site) and the forest edge by calculating mean values of annual increment. Tree-ring series used for the calculation of means had 'Gleichläufigkeit' $(G L)$ values $>60 \%(P \leq 0.05)$ and $t$-values $>3$; this applied to ca. $90 \%$ of the tree-ring series. Trend lines were calculated using moving 5-year averages because this method is a good compromise between the need to estimate a trend and the aim of keeping as much of the inter-annual (high-frequency) variation as possible.

Standardized tree-ring series were used in correlation analyses with climate parameters. The annual tree-ring index $\left(\mathrm{z}_{\mathrm{i}}\right)$ of year $\mathrm{i}$ was calculated with the equation $\mathrm{z}_{\mathrm{i}}=\mathrm{w}_{\mathrm{i}} / \mathrm{m}_{\mathrm{i}}$ with $\mathrm{w}_{\mathrm{i}}$ being the observed tree-ring width and $\mathrm{m}_{\mathrm{i}}$ being the 5-year moving average of year $\mathrm{i}$. In addition to the age classes, tree-ring series were systematically checked for differing growth trends within each age class in the raw series and grouped accordingly based on $G L$ and $t$-values into a total of 22 groups (named as groups A to V). Furthermore, the grouping of trees was controlled by non-metric multidimensional scaling (NMDS) of the tree-ring series and by one-way analysis of similarities (ANOSIM) with 9999 permutations (Clarke, 1993). 

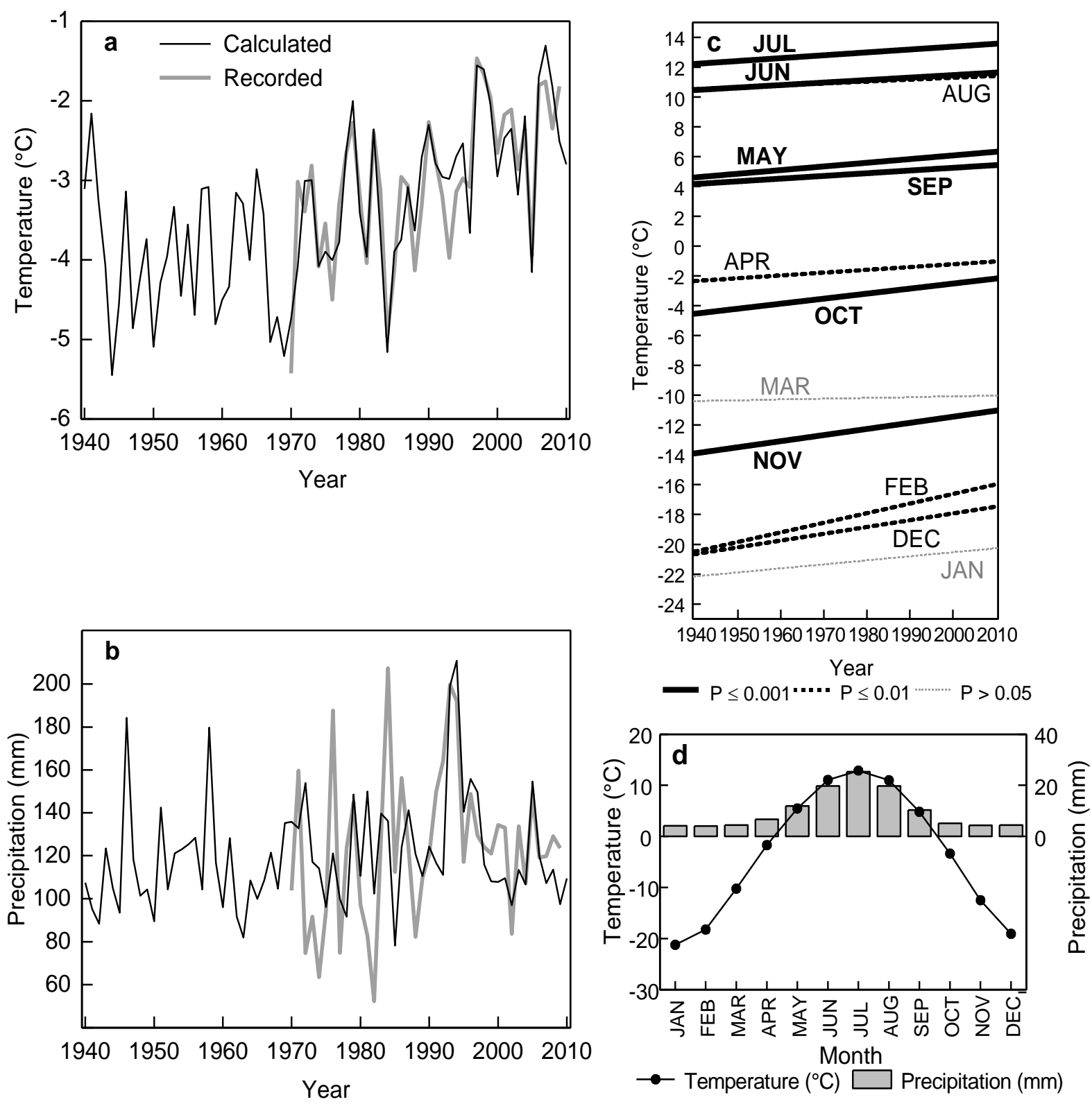

Fig. 3.1. Trends in (a, c) air temperature and (b) precipitation as well as (d) climate chart for the weather station Altai (48 $17^{\prime}$ N, 89³1' E, 2150 m a.s.l.), western Mongolia from 1940 to 2010 (71 years). (a) Annual mean temperature. (b) Annual precipitation. (c) Trends of monthly mean temperatures (only regression lines are plotted). Calculated values $(a, b)$ are based on linear regression across all months with data from the weather station Ulgii City.

Slopes of linear regression lines calculated for intervals (from 1960 to 2010) of the tree-ring series to analyze differing growth trends were compared with a one-way analysis of covariance (ANCOVA); this was done to reduce subjectivity in the assessment of the importance of increases or decreases of the annual stem increment relative to other groups of trees. Except for differences 
between individual regional growth curves (RGC; see below), these results are not presented, but positive tesing $(P \leq 0.05)$ was incorporated in the characterization of the divergent growth behaviour of different tree groups. Tree-ring series were representative of the studied stands as shown by the calculation of the expressed population signal (EPS) using sums of squares of within-core variation and error sums of squares calculated in a two-way analysis of variance (ANOVA) (Wigley et al., 1984). The EPS calculated separately for the age group and the habitat (forest interior vs. edge) exceeded the 0.85-threshold in most groups of trees united to a group with synchronous growth characteristics, except for 4 out of 22 groups, where EPS was $>0.80$ (Table 3.S1, see online supplementary material). Mean sensitivity and autocorrelation coefficients were calculated from raw increment data over the whole lifespan of each sample tree and for shorter intervals (varying between 13 and 21 years). The lengths of the individual intervals were constituted by considering striking changes in the growth rates of individual groups of trees.

Relationships of tree-ring width with climate were analyzed in multiple regression analyses, which were carried out separately for the different age classes. The climate data were related to standardized tree-ring chronologies. Monthly mean temperature and monthly precipitation of the current and the preceding year of tree-ring formation were included in the climate-response analysis. The regression analysis covered the period 1941-2009 for temperature and 1970 to 2009 for precipitation. Standardized $\beta$ coefficients were used to quantify the influence of individual months in the climate-response analysis. The effects of long-term (low-frequency) climate trends were deduced from RGC by comparing tree-ring series from trees of different age; RGC were calculated for the largest tree groups of each age class. These groups were also subdominant trees, which are more strongly influenced by climate than dominant or suppressed trees.

The frequency of selective logging over time in the six sites was assessed by controlling all individual tree-ring series from the 1826 growing on the sample plots for sudden increases of treering width. Such sudden increases that exceeded the usual variation by warm and cold years were interpreted as an indicator for the removal of trees from the direct neighborhood of the given tree. The disappearance of trees can theoretically result from natural mortality or natural or anthropogenic disturbance. Today anthropogenic disturbance in the form of logging clearly exceeds all other possible causes, at least according to our experiences after 2 years of field work in the study area and the results of interviews to forest use with 92 nomad families having their 
summer camps near our study sites. Sharp increases of tree-ring width which were interpreted as the removal of tree individuals of direct neighbors were separately analyzed for the six sites and for the forest interior versus the forest edge. The analysis was conducted for the periods from 1935 to 2010 in the forest interior and from 1963 to 2010 at the forest edge where trees were younger. The occurrence of sharp increases in $>1 \%$ of the trees was taken as an indicator for moderate selective logging (of single or few tree individuals), whereas sharp increases of the annual increment in $>10 \%$ of the trees was interpreted as an indicator of heavy selective logging (of many tree individuals). Potential errors by overestimating logging due to the classification of natural tree mortality as selective logging is inherent to the method, but as stated above this error is considered to be low at least in the recent past.

\subsubsection{Statistics}

Arithmetic means \pm standard errors are presented throughout the article; the use of weighted averages considering the different sample sizes of individual tree groups in some cases is noted in the text. The Wilcoxon two-sample test (U-test) was applied for testing the statistical significance of differences between two samples after negatively testing for normal distribution with the Shapiro-Wilk test. Multiple comparisons of normally distributed data were made using Duncan's multiple range test. Spearman rank correlation coefficients $\left(r_{s}\right)$ were calculated to analyze relationships between stump and tree densities and human population density. Four-way ANOVA was calculated to analyze the effect of the dominance type, the intraspecific competition class, tree age and the plot on mean tree-ring width for two alternative periods (1970-2010 and 1990-2010). The ANCOVA, ANOSIM and NMDS were calculated using PAST 2.15 software (Ǿ. Hammer, Natural History Museum, University of Oslo, Norway). All other statistical analyses, including the multiple regression analyses and the above-mentioned ANOVAs for calculating the EPS, were calculated with SAS 9.13 software (SAS Institute Inc., Cary, North Carolina, U.S.A.). Degrees of freedom for all analyses which include an $F$ test are specified as $\mathrm{df}=\mathrm{df}_{\text {model }}, \mathrm{df}_{\text {error }}$. 


\subsection{Results}

\subsubsection{Climate trends}

Annual mean temperature in the period from 1940 to 2011 was $-3.4 \pm 0.1{ }^{\circ} \mathrm{C}$, with a July temperature of $12.9 \pm 0.1{ }^{\circ} \mathrm{C}$ and a January temperature of $-21.2 \pm 3.4{ }^{\circ} \mathrm{C}$ (Fig. 3.1d). The annual mean temperature has increased by $2.1^{\circ} \mathrm{C}$ from -4.4 to $-2.3{ }^{\circ} \mathrm{C}$ since $1940(r=0.57, P<0.001, y=$ $0.03 x-57.2$ ) (Fig. 3.1a). Temperature has been subjected to a significant increase in all months, except for January and March (Fig. 3.1c). Annual precipitation was highly variable and ranged from 78 to $211 \mathrm{~mm}$ in the reconstructed data from 1940 to 2010 and from 52 to $207 \mathrm{~mm}$ in the data instrumental between 1970 and 2010. The mean from 1940 to 2010 amounted to $120 \pm 3 \mathrm{~mm}$ (and $124 \pm 6 \mathrm{~mm}$ in the instrumental data from 1970 to 2010); $54 \%$ of the total precipitation was received from June to August (Fig. 3.1d). There was no significant trend for changes in precipitation, neither with respect to annual (Fig. 3.1b) nor monthly values. This applied for both the instrumental data from 1970 to 2010 and the reconstructed data from 1940 to 2010.

\subsubsection{Radial stem increment}

Tree-ring width series varied between the habitats (forest interior vs. edge), age classes and even within age classes. Seven percent of the total of 1826 trees growing on the sample plots belonged to the very old trees with a cambium age $>160 \mathrm{yr}$ and $9 \%$ to the old trees (101-160 years), whereas the majority of trees was middle-aged (60-100 years; $47 \%$ ) or young (<60 years; $38 \%$; Table 3.1). The very old trees have established in the late 17 th century and have a cambium age at sampling height of up to 330 years (Fig. 3.2).

Within each age class and habitat (forest interior, forest edge), we could establish groups of trees with different trends in the annual stem increment. These groups were established not only based on classical $t$ - and $G L$-thresholds, but also with calculating NMDS (Fig. 3.3) and ANOSIM (Table 3.2). The different groups of trees within age class and habitat differed in the mean annual increment and in trends for decrease or increase in tree-ring width over time (Tables 3.2 and 3.S2, see online supplementary material). ANOVA showed that the mean tree-ring width (for the two 
alternatively studied intervals from 1970 to 2010 and from 1990 to 2010) was significantly influenced by the dominance type (dominant, subdominant and suppressed) of the tree and to a lower degree by the distance to the next competing tree, the age or the plot (Table 3.S3, see online supplementary material). Repeatedly groups of trees were found, which gradually or more often suddenly started to exhibit strongly increased annual stem increment contrary to the usually observed long-term trend for declining tree-ring width with increasing tree age (Tables 3.2 and Table 3.S2, see online

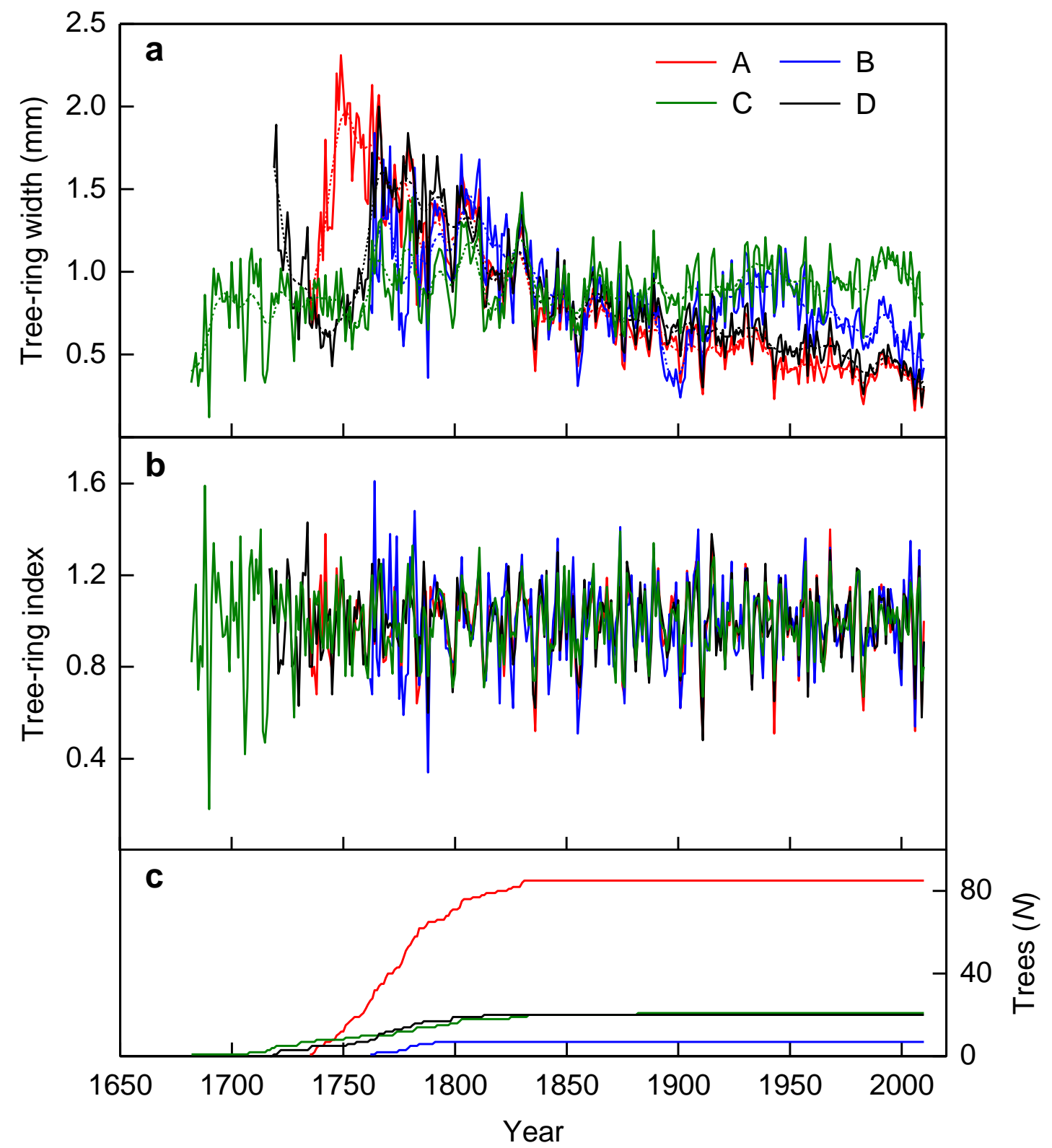

Fig. 3.2. Tree-ring chronologies for the very old trees (cambial age $>160$ years) from the interior (groups A, B) and the edge (groups C, D) of the forest including different growth trends in the forest interior during the past 100 years and at the forest edge during the past 130 years. (a) Tree-ring width. (b) Tree-ring index. (c) Number of samples. 
supplementary material), as is shown in the tree-ring chronologies of the different groups of old (Fig. 3.4) and middle-aged (Fig. 3.5) trees from the forest interior. Sudden increases in tree-ring width were especially found after 1990 (groups J, N, O, R, T and U; Fig. 3.6).

\subsubsection{Mean sensitivity and first-order autocorrelation}

The individual groups of trees differed in mean sensitivity and first-order autocorrelation coefficients even within the same age class (Table 3.S1, see online supplementary material). Furthermore, mean sensitivity and autocorrelation strongly differed between different time intervals (Table 3.S4, see online supplementary material). In most groups of trees, mean sensitivity was higher between 1941 and 1961 and in the recent past (1998-2010) than in the period from 1962 to 1997. Temporal patterns of autocorrelation were less regular than for mean sensitivity. Across all age classes, high mean ring width was mostly related with low mean sensitivity and high autocorrelation. This was valid for dominant trees with permanently high tree-ring widths (mean tree-ring width $>1 \mathrm{~mm}$; groups G, L and S) and for trees with sharp increases in the annual increment (e.g. groups F, I, J and N-P) (Tables 3.S1 and 3.S3, see online supplementary material). In the >160-year-old trees, this trend became only visible when decades with particularly high increment are isolated (group B in Table 3.S4), as otherwise the effects of the increased ring widths is blurred by the long period with lower growth rates.

\subsubsection{Climate-response analysis}

Except for the young (<60-year-old) trees, tree-ring width in almost all groups increased with June temperature of the current year. This was valid both for trees from the forest edge and the forest interior (Table 3.3). In the >160-year-old trees, tree-ring width in three out of four groups decreased with the June temperature of the year prior to tree-ring formation in addition to the increase with the June temperature of the current year; in group C and D (forest edge), the decrease was with June and July temperatures. 

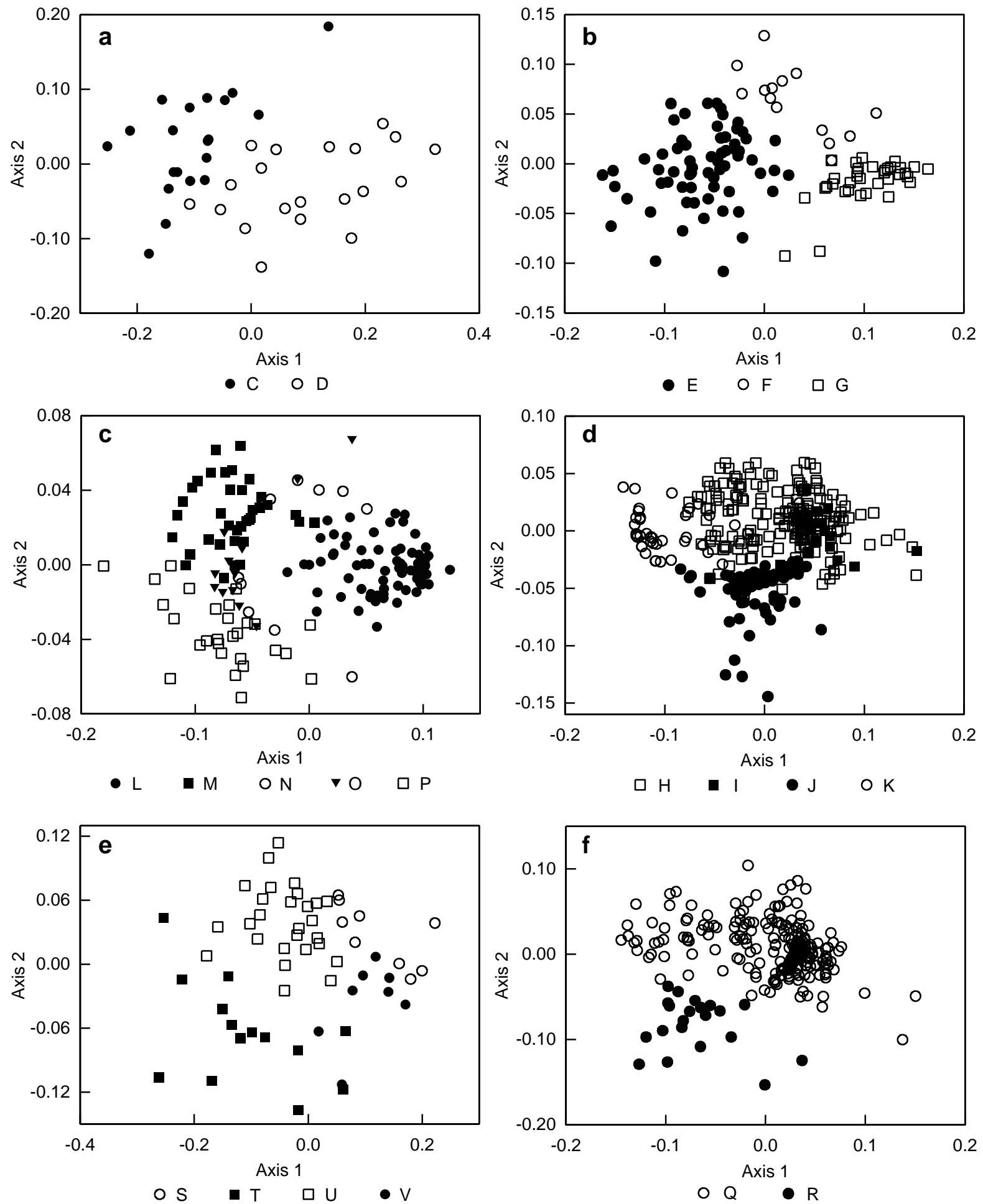

Figure. 3.3. NMDS ordination of tree-ring series from different age classes in the forest interior or the forest edge. (a) Very old trees (>160 years) from the forest edge. (b) Old trees (101-160 years) from the forest interior. (c, d) Middleage trees (60-100 years) from the $(c)$ forest interior or $(d)$ the forest edge. $(e, f)$ Young trees $(<60$ years) from the $(e)$ forest interior or (f) the forest edge. 
In the 101-160-year-old trees of group F, the annual increment increased with increasing temperature in May and June. Across tree groups of different age classes, negative correlations of tree-ring width with January temperature and positive correlations with February temperature and March precipitation of the current year were found. Positive correlation with precipitation during the growing season of the year prior to tree-ring formation were found in groups D (>160-year-old trees) and L (60-to 100-year-old trees) from the forest edge. Although young trees differed from the older trees by the lack of significant correlations with the June temperature of the current year, they showed more (positive or negative) correlations with monthly temperatures both of the current and the previous year than the trees of the other age classes.

Table 3.2. Characterization of groups of trees differing in their annual radial stem increment (RSI) behavior within ages classes and habitats.

\begin{tabular}{|c|c|c|c|c|c|}
\hline Group & Habitat & $N$ & $\begin{array}{l}\text { Ring width } \\
(\mathrm{mm})\end{array}$ & Characterization & ANOSIM $^{\mathrm{a}}$ \\
\hline A & FI & 92 & $0.84 \pm 0.01$ & Reduced RSI since c. 100 years & $* * *$ \\
\hline B & FI & 7 & $0.86 \pm 0.02$ & $\begin{array}{l}\text { Constant high, recently slightly } \\
\text { declining RSI }\end{array}$ & \\
\hline $\mathrm{C}$ & $\mathrm{FE}$ & 21 & $0.90 \pm 0.01$ & Constant high RSI & \\
\hline $\mathrm{D}$ & $\mathrm{FE}$ & 20 & $0.88 \pm 0.02$ & Reduced RSI since c. 100 years & \\
\hline $\mathrm{E}$ & FI & 64 & $0.35 \pm 0.01$ & Constant low RSI & $* * *$ \\
\hline $\mathrm{F}$ & FI & 14 & $0.58 \pm 0.03$ & $\begin{array}{l}\text { Higher RSI than E in the late } 19 \text { th } \\
\text { century, increase in the } 1970 \mathrm{~s}\end{array}$ & \\
\hline G & FI & 35 & $1.18 \pm 0.03$ & Very high RSI until c. 1940, high RSI & \\
\hline $\mathrm{H}$ & FI & 245 & $0.41 \pm 0.01$ & Constant modest RSI & $* * *$ \\
\hline I & FI & 17 & $0.48 \pm 0.04$ & Low RSI, strong increase c. 1970 & \\
\hline $\mathbf{J}$ & FI & 80 & $0.45 \pm 0.05$ & Low RSI, strong increase c. 1997 & \\
\hline K & FI & 37 & $0.33 \pm 0.01$ & $\begin{array}{l}\text { Constant decline, low RSI since the } \\
\text { 1960s }\end{array}$ & \\
\hline $\mathrm{L}$ & $\mathrm{FE}$ & 80 & $1.27 \pm 0.05$ & Constant high RSI & $* * *$ \\
\hline M & $\mathrm{FE}$ & 38 & $0.39 \pm 0.02$ & Constant low RSI & \\
\hline $\mathrm{N}$ & $\mathrm{FE}$ & 10 & $0.70 \pm 0.06$ & Modest RSI, increase since 1995 & \\
\hline $\mathrm{O}$ & $\mathrm{FE}$ & 14 & $0.48 \pm 0.04$ & Modest RSI, increase since 1999 & \\
\hline $\mathrm{P}$ & $\mathrm{FE}$ & 28 & $0.46 \pm 0.02$ & Constant decline, today low RSI & \\
\hline Q & FI & 224 & $0.50 \pm 0.02$ & Constant modest RSI & $* * *$ \\
\hline $\mathrm{R}$ & FI & 24 & $0.58 \pm 0.05$ & Modest RSI, increase since 1998 & \\
\hline S & $\mathrm{FE}$ & 9 & $1.46 \pm 0.08$ & Constant high RSI & $* * *$ \\
\hline $\mathrm{T}$ & $\mathrm{FE}$ & 14 & $0.47 \pm 0.03$ & Low RSI, gradual increase c. 1990 & \\
\hline $\mathrm{U}$ & $\mathrm{FE}$ & 31 & $0.59 \pm 0.03$ & Modest RSI, increase since 1997 & \\
\hline V & $\mathrm{FE}$ & 10 & $0.98 \pm 0.07$ & Modest RSI, increase since c. 1980 & \\
\hline
\end{tabular}

FI=forest interior; $\mathrm{FE}=$ forest edge.

${ }^{a}$ ANOSIM was calculated to test for significant differences between groups with a given age class and habitat $(* * * P \leq 0.001)$. 


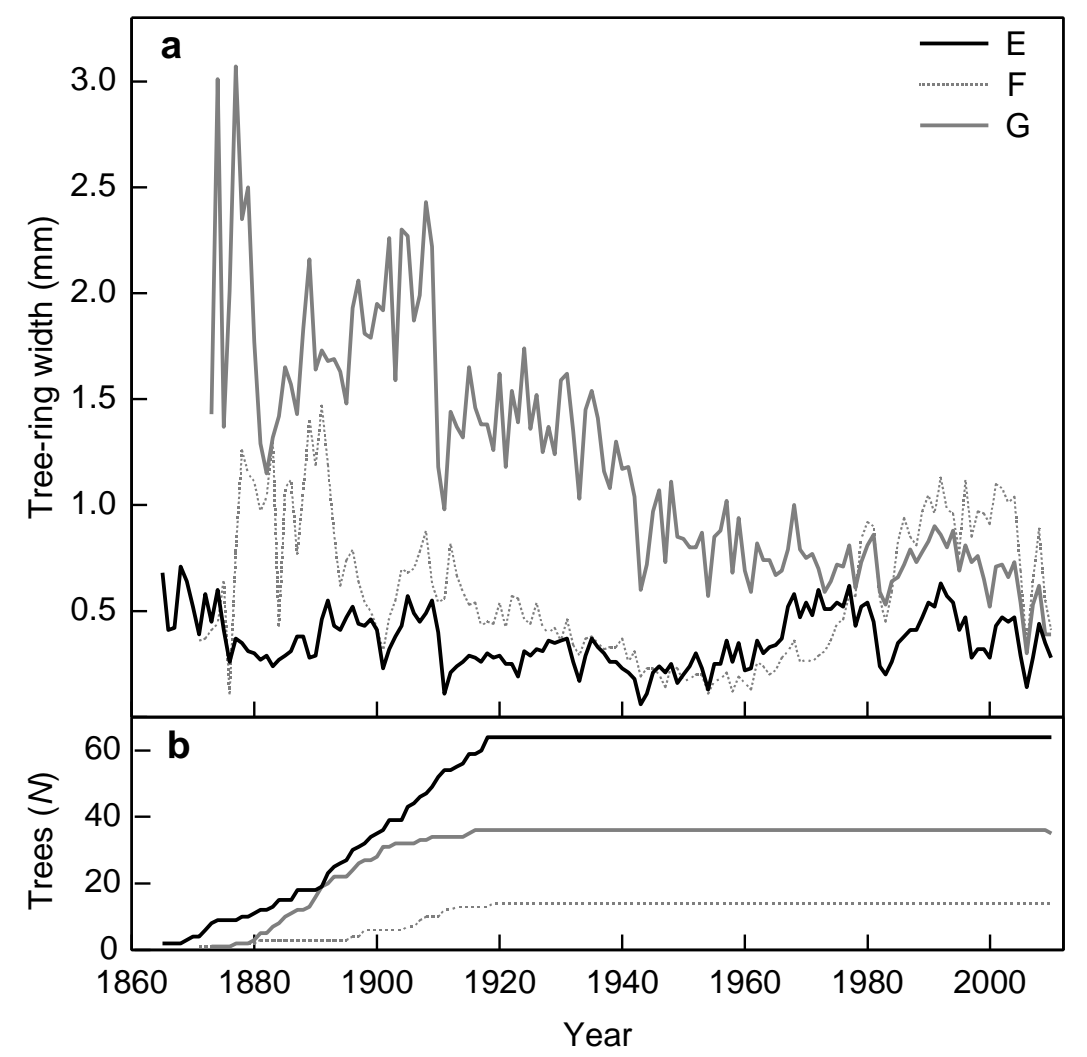

Figure. 3.4. Tree-ring chronology for old trees (cambial age 101-160 years) from the forest interior with three groups of trees (G, E and F) with different growth characteristics. (a) Tree-ring width. (b) Number of samples.

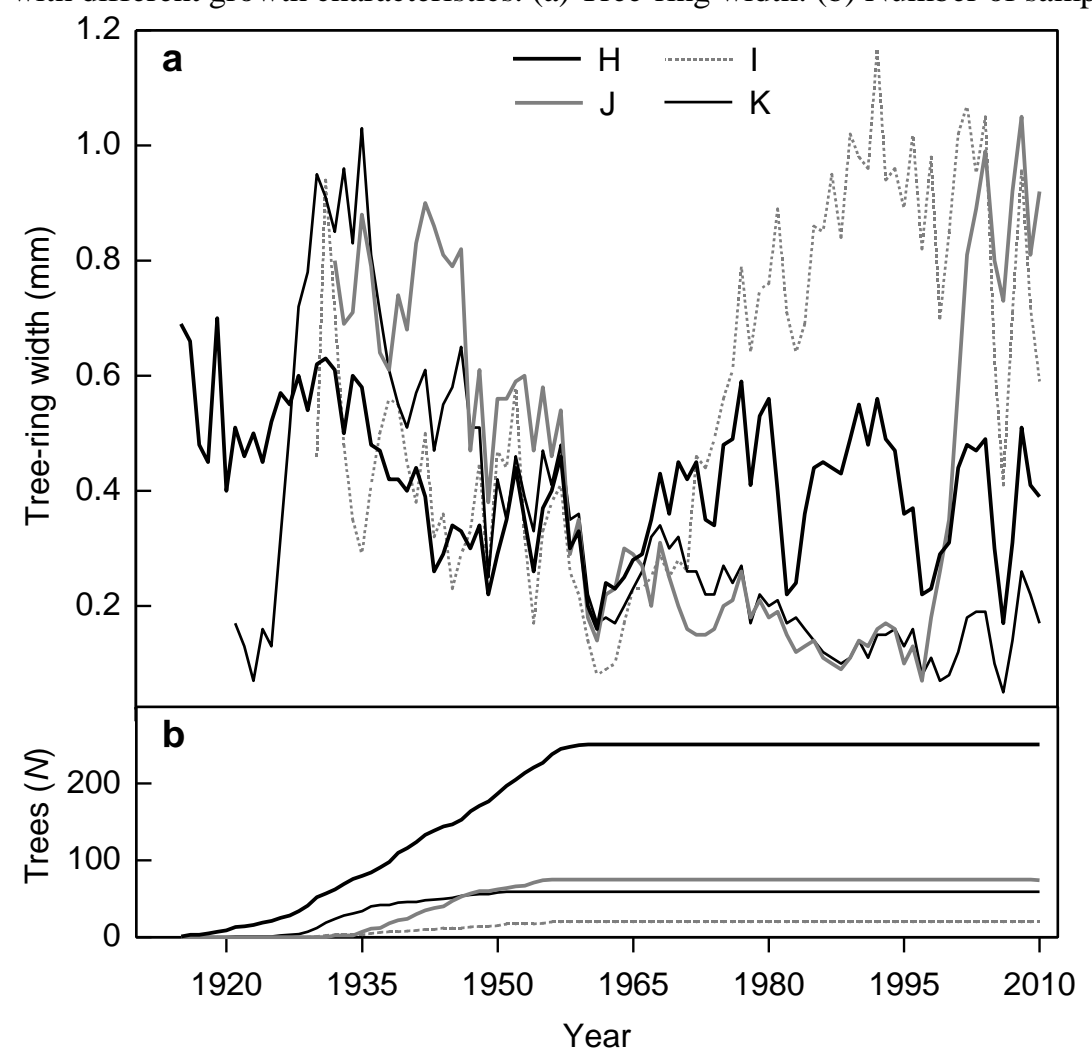

Figure. 3.5. Tree-ring chronology for middle-aged trees (cambial age 60-100 years) from the forest interior with four groups of trees (H, I, J and K) with different growth characteristics. (a) Tree-ring width. (b) Number of samples. 


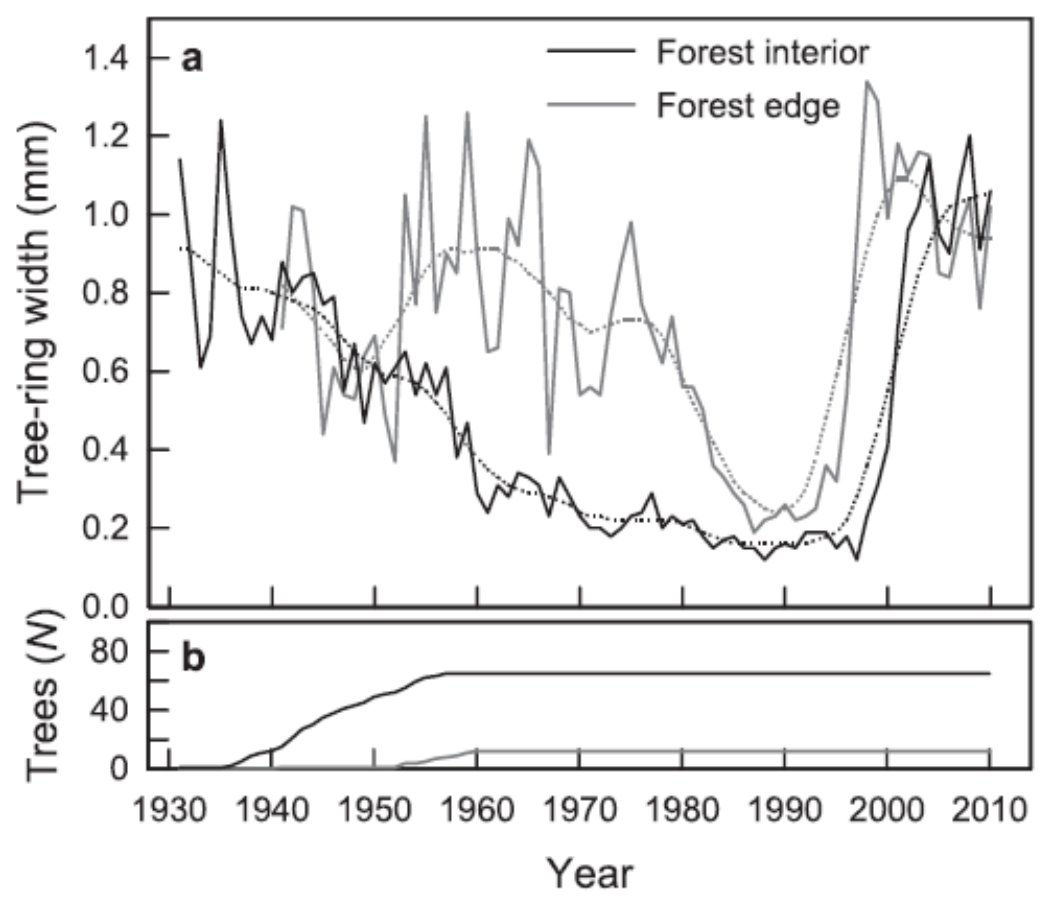

Figure 3.6. Tree-ring width in middle-aged trees at site 1 showing a sudden increase in the annual stem increment in 1995 at the forest edge (group $\mathrm{N}$ trees) and time delayed in 1997 in the forest interior (group J trees): (a) tree-ring width, (b) number of sample trees $(N)$.

Although the negative correlation of tree-ring width with June temperature of the previous year was only statistically significant in the very old trees, there was a concurrent, but insignificant trend in the old trees. The $\beta$ value for this correlation with June temperature of the year prior to tree-ring formation decreased along with tree age (Fig. 3.7). This decline coincided with a decline of the first-order autocorrelation coefficient and mean sensitivity with tree age (Fig. 3.7).

\subsubsection{Regional growth curves}

RGCs show that old trees grew generally more slowly when they were young than presently young trees did in the recent past at the same age (Fig. 3.8). The slope of linear regression lines calculated for the age interval for which data are available from all age classes differed significantly from one another in the ANCOVA $(P<0.001)$. Characteristic of the RGC for old and middle-age trees is that they have an inverse sigmoid shape with the inflection point 40 to 60 years ago. 


\subsubsection{Tree stump densities and logging frequency}

The total number of tree stumps found in the sample plots was $2079 \pm 282 \mathrm{ha}^{-1}$ in the forest interior and 1629 \pm 197 tree stumps per ha at the forest edge (Fig. 3.9a). The ratio of tree stumps to live trees was generally high and significantly higher at the forest edge than in the interior (Fig. 3.9b). At the forest edge, there were more stumps than living trees $(1.17 \pm 0.23)$, whereas approximately two living trees came on each stump in the forest interior $(0.48 \pm 0.05)$. The ratio of stumps to live trees increased significantly with the number of nomad summer camps within a radius of $1 \mathrm{~km}$ from the plot in the forest interior $\left(\mathrm{r}_{\mathrm{s}}=0.94, P=0.005\right)$, but not at the forest edge $\left(\mathrm{r}_{\mathrm{s}}=0.61, P=0.20\right)$.

Estimates of selective logging intensity and frequency based on sharp increases of individual tree-ring series are compiled in Fig. 3.10. Early heavy selective logging was observed at few sites during the 1960s and the 1970s at the forest edge and in the 1970s in the forest interior. After a break from the mid-1970s to the late 1980s, heavy selective logging across all sites started in 1990. The highest intensity was found in the 1990s; in the first decade of the 21 st century evidence of heavy selective logging was significant, but reduced compared with the decade before. Moderate selective logging occurred throughout the observation period starting in 1935, but was increasingly detectable since the mid 1950s.

\subsection{Discussion}

Both climate and the sociopolitical framework for land use have strongly changed in the recent past and have thereby influenced forest growth in the Mongolian Altai. The strong increase in temperature by $2.1{ }^{\circ} \mathrm{C}$ within 70 years at constant precipitation has increased the productivity of Siberian larch, as is evident from recently increased tree-ring widths, which becomes apparent when the natural trend for steadily decreasing annual stem increment with tree age is filtered from the data (Fig. 3.8). In the largest tree groups from the forest interior among the old (group E, $N=64$; Fig. 3.4) and middle-aged (group $\mathrm{H}, \mathrm{N}=245$; Fig. 3.5) trees, the gradual increase in the annual increment since the mid 20th century even overcompensated for the age-related trend in the absolute tree-ring widths. The high altitude of the study area (ca. $2300 \mathrm{~m}$ a.s.1.) and the subzero annual mean temperature cause that the radial stem increment of Siberian larch is primarily limited 
by low temperature (Table 3.3). Thus, the investigated forests in the Mongolian Altai show the typical behavior of a forest at the alpine treeline (Jacoby et al., 1996). Because temperature increases with decreasing altitude, it cannot be the cause of the lower forest line to the steppe at the footslope of the studied mountains. At lower elevations in central Mongolia, tree-ring width at these lower forest lines is limited by summer drought (Dulamsuren et al., 2011). In the Mongolian Altai, the position of the forest line is apparently not controlled by climate, but largely anthropogenic.

Although not controlling the forest lines, precipitation also plays a significant role for the stem increment of Siberian larch in the Mongolian Altai. Precipitation in the summer of the current year was less relevant than that in spring before foliation and, more rarely, that during the growing season of the previous year. The correlation with spring precipitation (which is received as snow) or sporadically with the precipitation of the previous year suggests that soil water replenishment before the growing season is significant for earlywood formation (Nikolaev et al., 2009). The lacking correlation with summer precipitation of the current year, combined with the low annual precipitation indicates that the active layer of the permafrost is of great importance for the water supply of the forests in summer.

The active layer prevents the infiltration of the precipitation in deep soil layers and supplies the vegetation by thawing during the summer with water, which adds to the current precipitation. The contribution of the uppermost permafrost layer to the water supply of boreal forests is well studied in other areas (Kenneth et al., 1995; Iwahana et al., 2005; Sugimoto et al., 2002;), but data from the Mongolian Altai are lacking (Sharkhuu and Sharkhuu, 2012). However, the existence of coniferous forests in the study area at a level of annual precipitation near $120 \mathrm{~mm}$ is (even though the figure may be somewhat underestimated) not conceivable without a major contribution of the active permafrost layer to the water supply. In the forest-steppe of central and northern Mongolia, the annual precipitation in larch forests at lower elevation varies roughly between 230 and $400 \mathrm{~mm}$ (Dulamsuren et al., 2010a; Nandintsetseg et al., 2007). In these forests, the water status of Siberian larch trees has been found to depend much more on the current precipitation than in the Altai Mountains (Dulamsuren et al., 2009; Li et al., 2006, 2007). 
Table 3.3. Response of tree-ring width in the individual tree groups A to $Y$ (as defined in the text) to monthly temperature and precipitation of the year of and the year prior to tree-ring formation.

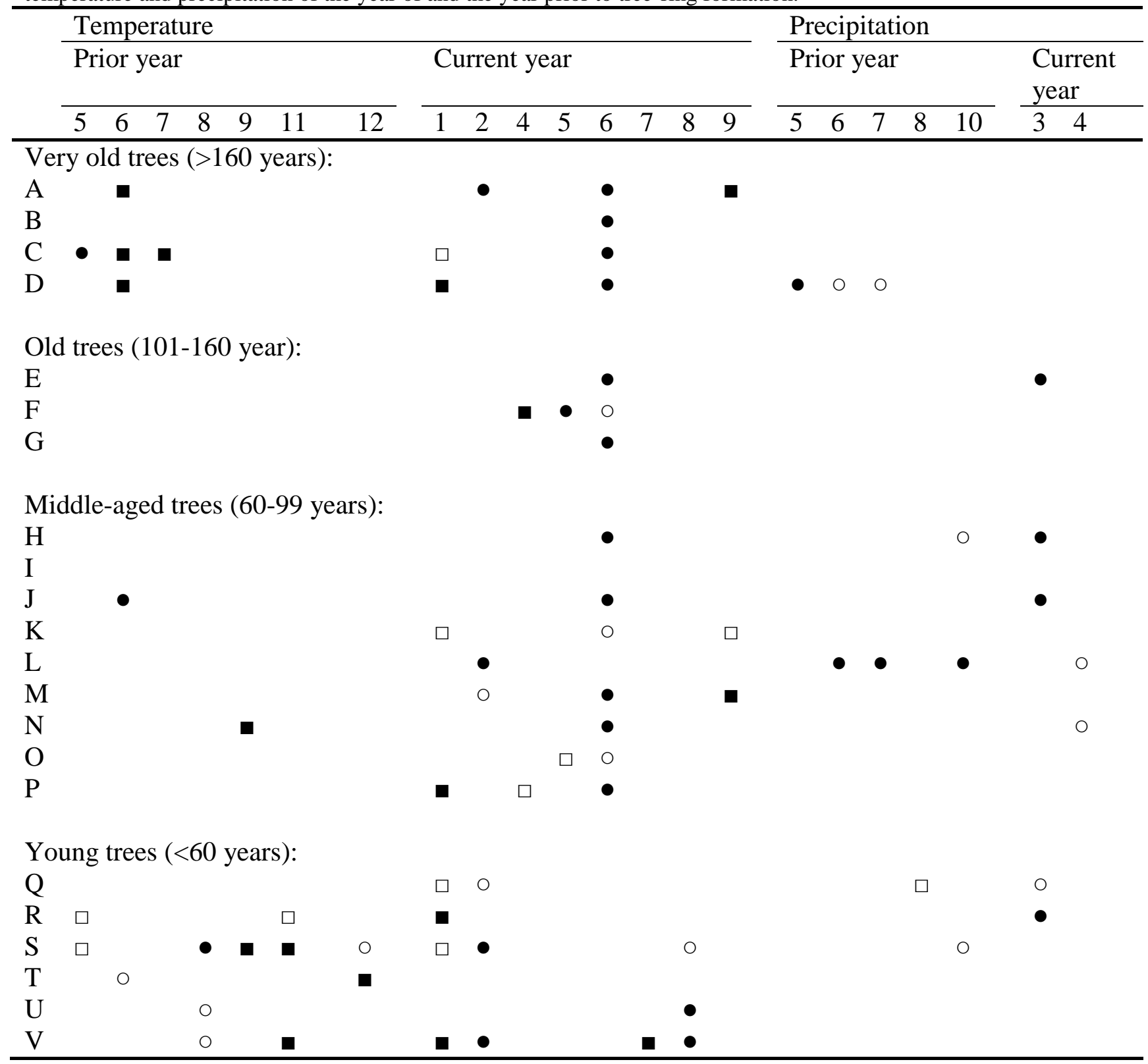

Beta values resulting from multiple regression analysis (cf. Table 3 ). Correlation significant $(P \leq 0.05)$ : $\bullet$ positive, $\boldsymbol{\bullet}$ negative correlation; marginally significant $(P \leq 0.10)$ : $\circ$ positive, $\square$ negative correlation. Months are identified with numbers 1 to 12 .

The positive correlation of tree-ring widths with early summer (i.e. June), rather than midsummer, temperatures across all tree groups of the middle-aged, old and very old trees matches with the results from larch forests of the Russian Altai (Ovchinnikov, 2002) and the Siberian Subarctic, where cell sizes and cell wall thickness of both earlywood and latewood increased with June, but not July and August temperatures (Kirdyanov et al., 2003). The correlation of tree-ring width in 
the very old trees with low June temperature of the previous year (and high June temperature of the current year) is probably due to the accumulation of non-structural

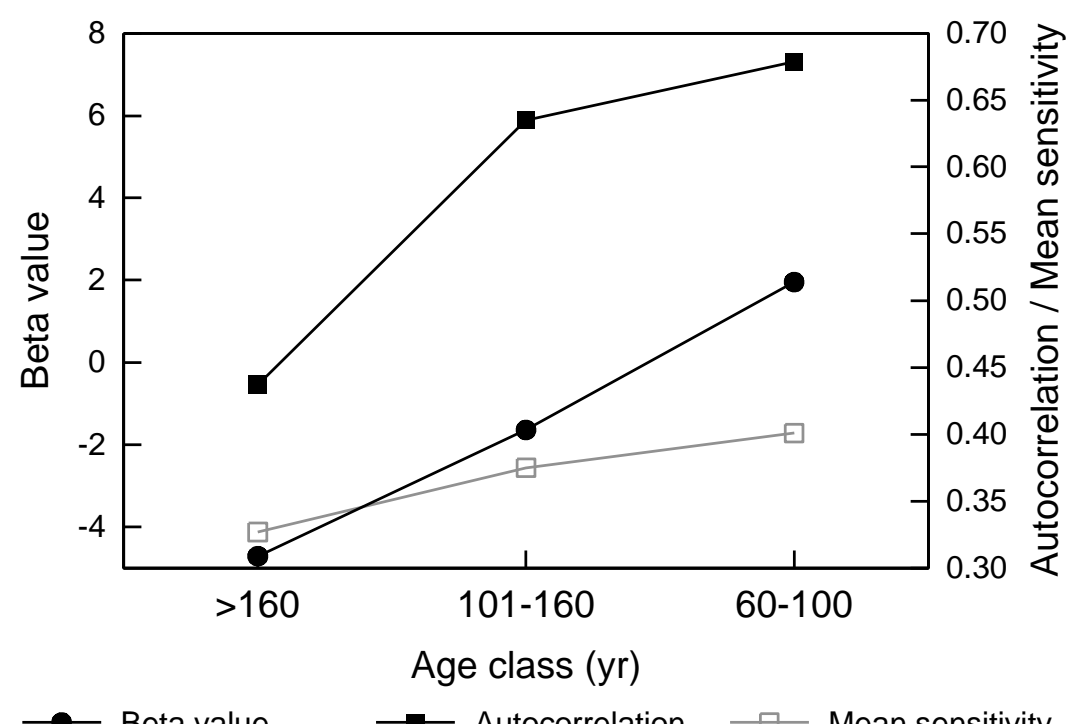

Fig. 3.7. Influence of tree age on first-order autocorrelation, mean sensitivity and the beta value for the correlation of the June temperature of the previous year with tree-ring width in $>60$-year old larch trees. Dots represent weighted arithmetic means.

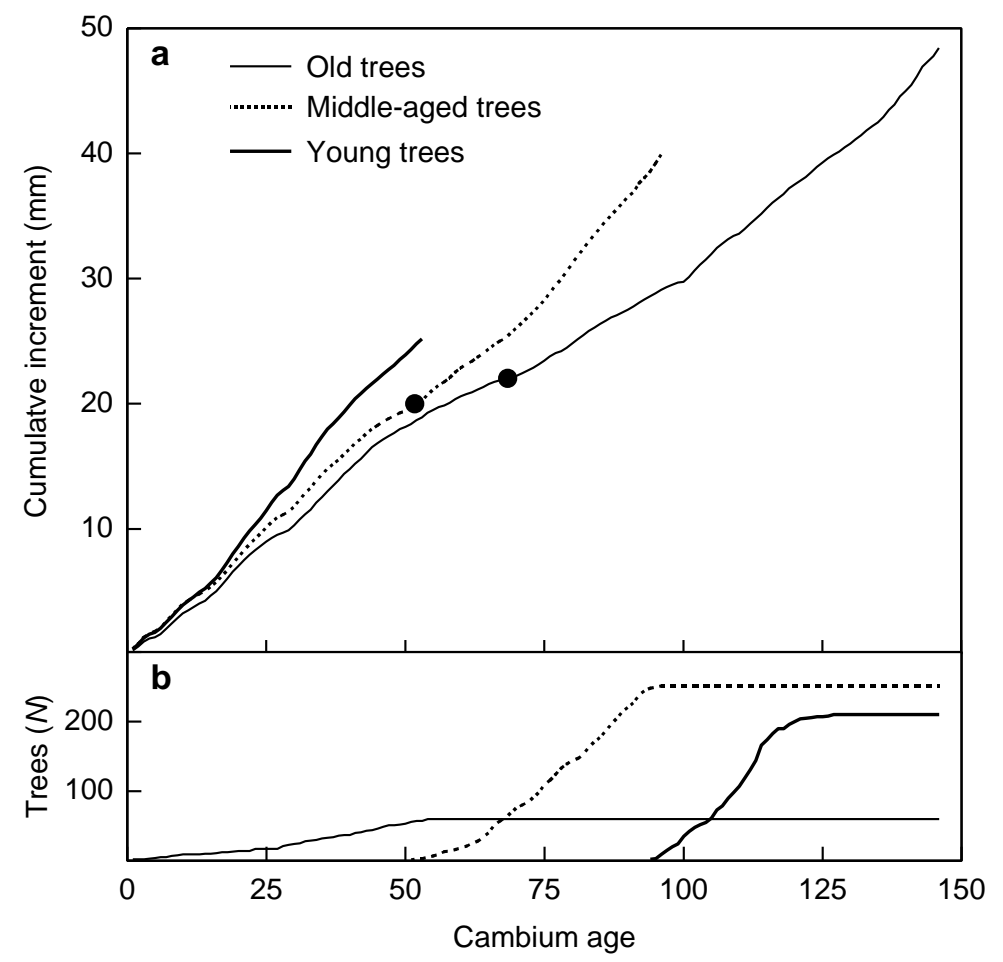

Fig. 3.8. Cumulative regional growth curve (a) with number of samples (b) for the largest groups of old (group E), middle-aged (group H) and young (group Q) trees from the forest interior of sites 1 to 6 . The slopes of linear regression lines calculated for the individual tree-ring series differ significantly (ANCOVA, $P<0.001, F=381$, df=2, 155). Filled dots mark inflection points. 
carbohydrates in years with cold early summers because wood formation is more readily inhibited by low temperatures than photosynthesis (Hoch and Körner, 2003). The stored non-structural carbohydrates could then be used to produce wider tree rings than usual in the following year. The fact that trees tend to store more non-structural carbohydrates with increasing size (Sala et al., 2012)
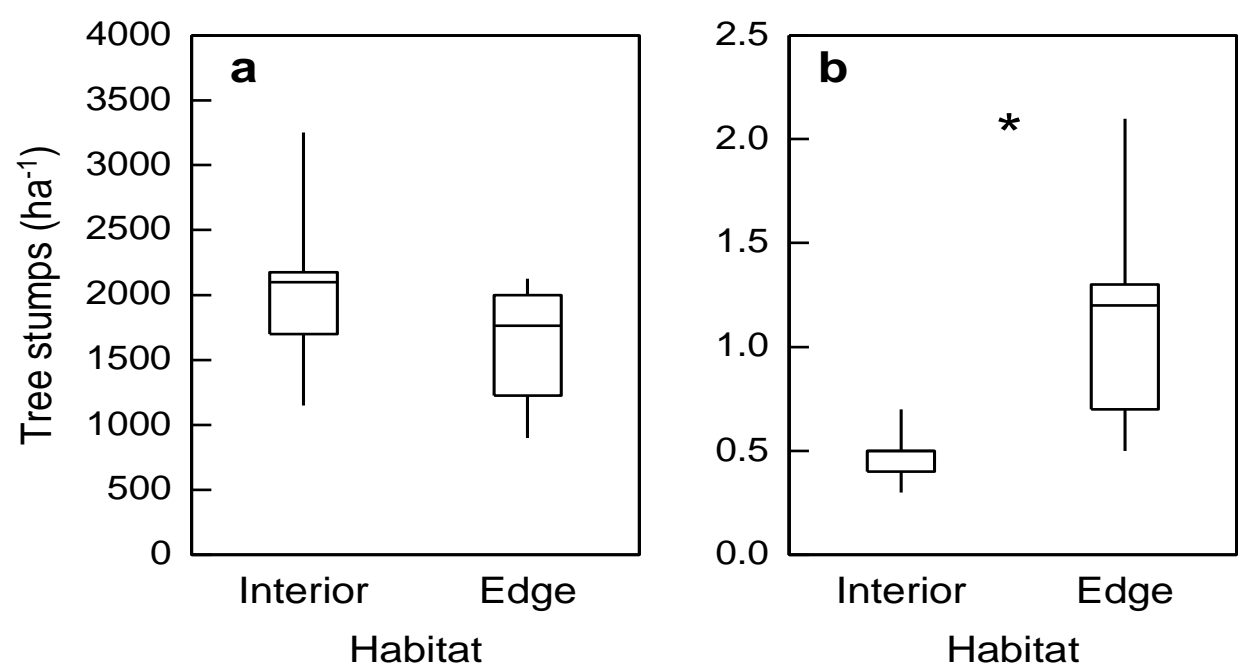

Fig. 3.9. Total numbers of tree stumps per hectare (a) and ratio of stumps to live trees (b) in the forest interior and the forest edge. Asterisk indicates significant difference (U-test, $P \leq 0.05$ ).

agrees with our result that a significant negative correlation of tree-ring width with June temperature of the previous year was only found in the oldest year, whereas a similar insignificant trend occurred in the old trees, but no such correlation existed in the middle-aged or young trees. Higher pools of non-structural carbohydrates allow the large trees to buffer climatic influences and other forms of stress more effectively (Sala and Hoch, 2009; Sala et al., 2012). This would explain the decrease of mean sensitivity and first-order autocorrelation from the middle-aged to the very old trees (Fig. 3.7), because cold early summers, which we identified as the key limiting factor for stem growth in the Mongolian Altai in the climate-response analysis (Table 3.3), would not cause negative aftereffects on tree-ring width in the following year.

The trend for increased radial stem growth in the Mongolian Altai agrees with other areas from western Mongolia where annual stem growth was found to be primarily temperaturedependent (D'Arrigo et al., 2000; Jacoby et al., 1996). It disagrees with the responses to late 20th century warming in most larch forests of central Mongolia where relevant studies were published. Decreasing tree-ring width along with increasing aridity was observed in the western and southern Khentei and the eastern Khangai Mountains (Dulamsuren et al., 2010a, b). 
The identification of several tree groups with different growth trends in each age class of larch trees in the Mongolian Altai suggests that factors other than climate are also effective at influencing the annual stem increment. One reason for the differentiation of different groups is the dominant versus suppressed social rank of trees within the same stand. Groups G, L and S are examples of dominant trees that might have better access to resources than the other trees. (Aussenac, 2000). The access to water and other resources is apparently less affected by the interannual variation of climate because the mean climate sensitivity in the dominant tree groups is lower than in the other trees of the same age group (Table 3.S1, see online supplementary material).
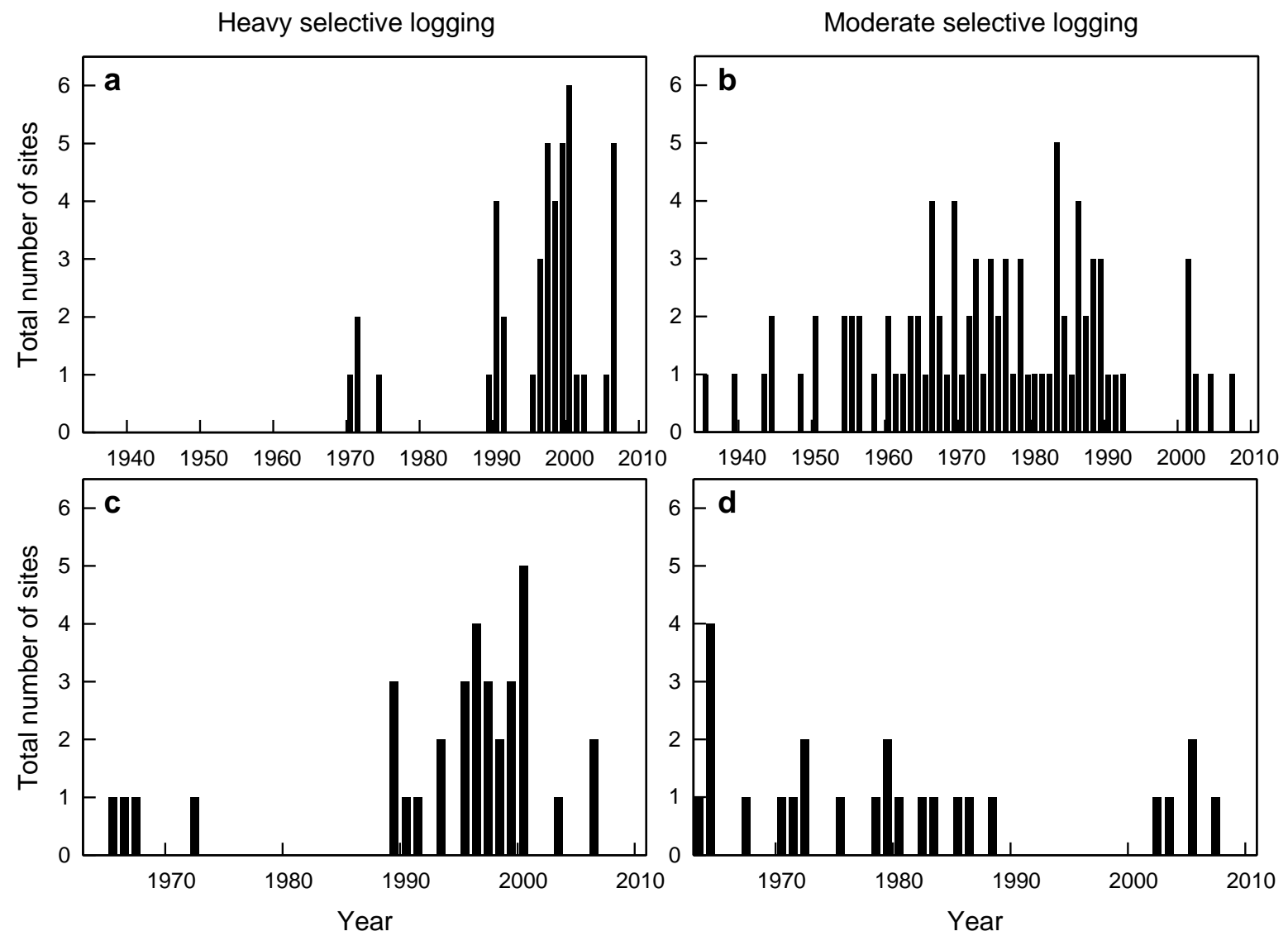

Fig. 3.10. Cumulative distribution plot of heavy ( $a$ and $c$ ) and moderate ( $b$ and d) selective logging in the six study sites in the forest interior ( $a$ and $b$ ) and the forest edge ( $c$ and d). Note that the analysis for the forest edge only covered the period from 1963 to 2010 because the tree age distribution differed from the forest interior.

Competition also explains why trees at the forest edge grew on average faster than trees in the forest interior (Dulamsuren et al., 2010b).

Sudden increases of the annual stem increment, which were repeatedly observed in the data set, are the result of singular disturbance events, including windfall or selective logging, which 
reduce the competition for the remaining trees. Selective logging on a moderate level took place throughout the 20th century. However, the strong increase of the frequency of sharp (permanent or temporary) leaps in tree-ring width in the 1990s is doubtlessly attributable to intensified selective logging. The high number of stumps in the sample plots (Fig. 3.9) and examples of leaps in the tree-ring series from the forest interior, which occur time-delayed from those in the series from the corresponding forest edge (Fig. 3.6), provide strong support for this explanation. The transition from centrally planned to marked economy with the displacement of the Communist system in 1990 considerably increased the demand for timber and fuelwood in Mongolia and was the breeding ground for unsystematic, often illegal logging and trading activities (Erdenechuluun, 2006). During Communist times, intense selective logging was only detectable from the mid-1960s to the early 1970s at the edges and in the early and mid-1970s in the interior of the forests, but these activities were much less widespread than those after 1990. Sharp increases were observed especially after cold years, which are likely to result both from the interannual temperature variation and intensified selective logging in cold periods with high fuelwood consumption. The rarity of sharp increases in the tree-ring series, which are likely to indicate selective felling, from the mid-1970s to the late 1980s suggests that the numerous tree stumps, which are presently found in the forests of the Mongolian Altai, predominantly derive from logging activities during the past 20 years. Given a ratio of live to felled trees of 2:1 in the forest interior or even $0.9: 1$ at the forest edge to the steppe, this conclusion means that the forests of the Mongolian Altai are presently exploited far beyond sustainability. The fact that the ratio of live to felled trees is correlated with human settlement density indicates that trees are primarily logged by the local population.

\subsection{Conclusions}

The larch forests of the Mongolian Altai have been subjected to significant increases in temperature since the mid-20th century and in the intensity of selective logging since the 1990s. Because the Altai Mountains are a cold high-elevation environment with a subzero annual mean temperature, the increase in temperature has promoted the growth of the Siberian larch trees. Notwithstanding the increased productivity due to improved climatic conditions, the forests have not benefitted from this development, as changed customs for forest utilization have increased the 
anthropogenic pressure on the forests after the breakdown of the Communist regime in 1990 (Lkhagvadorj et al., 2013). The present practice of unplanned selective logging by the local population of pastoral nomads will lead to a decline of forest area in the Mongolian Altai in the near future. The high degree of fragmentation of the forest sites, where the forests occur in isolated patches within the grassland, is an unfavorable precondition which is likely to promote a rapid decline of forested sites given the presently high land use pressure by pastoral nomads in the area (Lkhagvadorj et al., 2013).

\section{Supplementary data}

Supplementary Tables S1-S4. (available at Journal of Plant Ecology online)

Table 3.S1. Mean tree-ring width, mean sensitivity, first-order autocorrelation coefficient and expressed population signal (EPS) in the trees of A to V (as defined in the text) from the forest interior (FI) or the forest edge (FE).

\begin{tabular}{|c|c|c|c|c|c|c|}
\hline Group & Habitat & $N$ & Ring width $(\mathrm{mm})^{\mathrm{a}}$ & Mean sensitivity $^{a}$ & Autocorrelation $^{\mathrm{a}}$ & EPS \\
\hline \multicolumn{7}{|c|}{ Very old trees $(>160$ years; $d f=3,136)$ : } \\
\hline A & FI & 92 & $0.84 \pm 0.01$ & $0.32 \pm 0.01 \mathrm{a}$ & $0.77 \pm 0.01 \mathrm{a}$ & \\
\hline B & FI & 7 & $0.86 \pm 0.02$ & $0.31 \pm 0.02 b$ & $0.65 \pm 0.05 b$ & \\
\hline $\mathrm{C}$ & $\mathrm{FE}$ & 21 & $0.90 \pm 0.01$ & $0.27 \pm 0.01 \mathrm{c}$ & $0.63 \pm 0.03 \mathrm{c}$ & 0.8 \\
\hline $\mathrm{D}$ & $\mathrm{FE}$ & 20 & $0.88 \pm 0.02$ & $0.29 \pm 0.01 \mathrm{~d}$ & $0.76 \pm 0.03 \mathrm{~d}$ & \\
\hline
\end{tabular}

Old trees $(101-160$ years; $\mathrm{df}=2,115)$ :

$\begin{array}{lllllll}\mathrm{E} & \text { FI } & 64 & 0.35 \pm 0.01 & 0.42 \pm 0.01 \mathrm{a} & 0.68 \pm 0.02 \mathrm{a} & 0.90 \\ \mathrm{~F} & \text { FI } & 14 & 0.58 \pm 0.03 & 0.38 \pm 0.01 \mathrm{~b} & 0.80 \pm 0.01 \mathrm{~b} & 0.67 \\ \mathrm{G} & \text { FI } & 35 & 1.18 \pm 0.03 & 0.28 \pm 0.01 \mathrm{c} & 0.77 \pm 0.08 \mathrm{~b} & 0.94\end{array}$

Middle-aged trees (60-100 years; $\mathrm{df}=8,540)$ :

$\begin{array}{llrllll}\mathrm{H} & \text { FI } & 245 & 0.41 \pm 0.01 & 0.42 \pm 0.01 \mathrm{ab} & 0.65 \pm 0.01 \mathrm{a} & 0.97 \\ \mathrm{I} & \text { FI } & 17 & 0.48 \pm 0.04 & 0.39 \pm 0.02 \mathrm{a} & 0.78 \pm 0.02 \mathrm{bc} & 0.97 \\ \mathrm{~J} & \text { FI } & 80 & 0.45 \pm 0.05 & 0.39 \pm 0.01 \mathrm{a} & 0.83 \pm 0.02 \mathrm{~b} & 0.95 \\ \mathrm{~K} & \text { FI } & 37 & 0.33 \pm 0.01 & 0.42 \pm 0.01 \mathrm{ab} & 0.73 \pm 0.03 \mathrm{c} & 0.90 \\ \mathrm{~L} & \text { FE } & 80 & 1.27 \pm 0.05 & 0.29 \pm 0.01 \mathrm{c} & 0.65 \pm 0.01 \mathrm{ad} & 0.98 \\ \mathrm{M} & \text { FE } & 38 & 0.39 \pm 0.02 & 0.39 \pm 0.02 \mathrm{a} & 0.57 \pm 0.03 \mathrm{~d} & 0.91 \\ \mathrm{~N} & \text { FE } & 10 & 0.70 \pm 0.06 & 0.33 \pm 0.01 \mathrm{~d} & 0.76 \pm 0.02 \mathrm{bc} & 0.91 \\ \mathrm{O} & \text { FE } & 14 & 0.48 \pm 0.04 & 0.45 \pm 0.02 \mathrm{~b} & 0.74 \pm 0.03 \mathrm{c} & 0.83 \\ \mathrm{P} & \text { FE } & 28 & 0.46 \pm 0.02 & 0.44 \pm 0.01 \mathrm{~b} & 0.78 \pm 0.03 \mathrm{bc} & 0.85\end{array}$

Young trees $(<60$ years; $\mathrm{df}=5,399)$ :

$\begin{array}{llrllll}\mathrm{Q} & \mathrm{FI} & 224 & 0.50 \pm 0.02 & 0.38 \pm 0.01 \mathrm{ac} & 0.58 \pm 0.02 \mathrm{a} & 0.82 \\ \mathrm{R} & \mathrm{FI} & 24 & 0.58 \pm 0.05 & 0.39 \pm 0.03 \mathrm{ac} & 0.66 \pm 0.05 \mathrm{abc} & 0.88 \\ \mathrm{~S} & \mathrm{FE} & 9 & 1.46 \pm 0.08 & 0.25 \pm 0.01 \mathrm{~b} & 0.71 \pm 0.04 \mathrm{bc} & 0.84 \\ \mathrm{~T} & \mathrm{FE} & 14 & 0.47 \pm 0.03 & 0.40 \pm 0.02 \mathrm{a} & 0.75 \pm 0.03 \mathrm{c} & 0.81 \\ \mathrm{U} & \mathrm{FE} & 31 & 0.59 \pm 0.03 & 0.33 \pm 0.01 \mathrm{c} & 0.62 \pm 0.02 \mathrm{ab} & 0.94 \\ \mathrm{~V} & \mathrm{FE} & 10 & 0.98 \pm 0.07 & 0.34 \pm 0.02 \mathrm{c} & 0.67 \pm 0.04 \mathrm{abc} & 0.82\end{array}$

\footnotetext{
${ }^{\mathrm{a}}$ Within a column, but separate for the individual age classes, means followed by different letters, differ significantly (Duncan's multiple range test, $P \leq 0.05$ ).
} 
Table 3.S2. Mean tree-ring width, mean sensitivity, first-order autocorrelation coefficient and expressed population signal (EPS) in the trees of A to V (as defined in the text) from the forest interior (FI) or the forest edge (FE).

\begin{tabular}{|c|c|c|c|c|c|c|c|c|c|c|c|}
\hline \multirow[t]{2}{*}{ Group } & \multirow[t]{2}{*}{ Habitat $^{\mathrm{a}}$} & \multicolumn{2}{|c|}{ Trees $^{b}$} & \multicolumn{7}{|c|}{ Mean ring width $(\mathrm{mm})^{\mathrm{c}}$} & \multirow{2}{*}{$\begin{array}{l}\text { Year of } \\
\text { increase }^{d}\end{array}$} \\
\hline & & $N$ & $\%$ & 1991 & 1971 & 1951 & 1931 & 1911 & 1891 & 1871 & \\
\hline \multicolumn{12}{|c|}{ Very old trees $(>160$ years; $d f=3,136)$ : } \\
\hline A & FI & 92 & 93 & 0.38 & 0.38 & 0.43 & 0.51 & 0.54 & 0.57 & 0.62 & \\
\hline B & FI & 7 & 7 & 0.59 & 0.65 & 0.78 & 0.93 & 0.79 & 0.51 & 0.76 & \\
\hline $\mathrm{C}$ & $\mathrm{FE}$ & 21 & 51 & 0.98 & 0.93 & 0.92 & 1.02 & 0.89 & 0.88 & 0.86 & \\
\hline $\mathrm{D}$ & $\mathrm{FE}$ & 20 & 49 & 0.41 & 0.44 & 0.54 & 0.58 & 0.63 & 0.67 & 0.71 & \\
\hline \multicolumn{12}{|c|}{ Old trees $(101-160$ years; $d f=2,115)$ : } \\
\hline $\mathrm{E}$ & FI & 64 & 57 & 0.40 & 0.45 & 0.33 & 0.23 & 0.28 & 0.45 & 0.35 & \\
\hline $\mathrm{F}$ & FI & 14 & 12 & 0.87 & 0.65 & 0.21 & 0.29 & 0.51 & 0.70 & 0.85 & 1965 \\
\hline G & FI & 35 & 31 & 0.66 & 0.71 & 0.78 & 1.11 & 1.40 & 1.89 & 1.83 & \\
\hline \multicolumn{12}{|c|}{ Middle-aged trees $(60-100$ years; $\mathrm{df}=8,540)$ : } \\
\hline $\mathrm{H}$ & FI & 245 & 65 & 0.39 & 0.43 & 0.33 & $(0.42)$ & & & & \\
\hline I & FI & 17 & 5 & 0.87 & 0.71 & 0.26 & $(0.44)$ & & & & 1970 \\
\hline $\mathrm{J}$ & FI & 80 & 21 & 0.51 & 0.16 & 0.35 & $(0.71)$ & & & & 1997 \\
\hline K & FI & 37 & 10 & 0.14 & 0.19 & 0.32 & $(0.65)$ & & & & \\
\hline $\mathrm{L}$ & $\mathrm{FE}$ & 80 & 47 & 1.11 & 1.25 & 1.56 & $(0.94)$ & & & & \\
\hline M & $\mathrm{FE}$ & 38 & 22 & 0.42 & 0.37 & 0.41 & 0.26 & $(0.31)$ & & & \\
\hline $\mathrm{N}$ & $\mathrm{FE}$ & 10 & 6 & 0.83 & 0.52 & 0.83 & $(0.70)$ & & & & 1995 \\
\hline $\mathrm{O}$ & $\mathrm{FE}$ & 14 & 8 & 0.33 & 0.27 & 0.68 & $(0.87)$ & & & & 1999 \\
\hline $\mathrm{P}$ & $\mathrm{FE}$ & 28 & 17 & 0.15 & 0.31 & 0.77 & $(0.74)$ & & & & \\
\hline \multicolumn{12}{|c|}{ Young trees $(<60$ years; $d f=5,399)$ : } \\
\hline Q & FI & 224 & 90 & 0.44 & 0.64 & $(0.40)$ & & & & & \\
\hline $\mathrm{R}$ & FI & 24 & 10 & 0.70 & 0.46 & $(0.59)$ & & & & & 1998 \\
\hline S & $\mathrm{FE}$ & 9 & 14 & 1.22 & 1.46 & (1.94) & & & & & \\
\hline $\mathrm{T}$ & $\mathrm{FE}$ & 14 & 22 & 0.63 & 0.50 & 0.35 & $(0.70)$ & & & & 1990 \\
\hline $\mathrm{U}$ & $\mathrm{FE}$ & 31 & 48 & 1.22 & 0.63 & 0.56 & $(0.58)$ & & & & 1997 \\
\hline $\mathrm{V}$ & $\mathrm{FE}$ & 10 & 16 & 1.29 & 1.30 & 0.76 & $(0.76)$ & & & & 1980 \\
\hline
\end{tabular}

${ }^{\mathrm{a}}$ Forest interior (FI) or forest edge (FE).

${ }^{\mathrm{b}}$ Absolute number of sample trees $(N)$ and percentage of the total trees of the same age ground and in the same habitat $(\%)$.

${ }^{c}$ Mean ring width in 20-yr intervals starting with the given in the headline; values in brackets refer to parts of the 20yr period.

d Year of strong increment in tree-ring width. 
Table 3.S3: Results of four-way ANOVA analyzing the effect of the dominance type (dominant, subdominant, suppressed), the intraspecific competition class (nearest neighbor at $<1 \mathrm{~m}, 1-2 \mathrm{~m},>2 \mathrm{~m}$ distance), tree age and the plot on mean tree-ring width in the forest interior and at the forest edge for two alternative periods (1970-2010, 19902010). ${ }^{\mathrm{a}}$

\begin{tabular}{llllll}
\hline & Forest interior & & & \multicolumn{2}{l}{ Forest edge } \\
\cline { 2 - 3 } \cline { 5 - 6 } Total $(\mathrm{df}=36)$ & $1970-2010$ & $1990-2010$ & & $1970-2010$ & $1990-2010$ \\
& $17.1^{2} * *$ & $15.0^{* * *}$ & & $16.0^{* * *}$ & $10.7 * * *$ \\
Dominance & $\left(R^{2}=0.43\right)$ & $\left(R^{2}=0.40\right)$ & & $\left(R^{2}=0.56\right)$ & $\left(R^{2}=0.46\right)$ \\
Competition & $81.7^{* * *}$ & $65.5^{* * *}$ & & $62.2^{* * *}$ & $46.7^{* * *}$ \\
Age & $27.8^{* * *}$ & $25.6^{* * *}$ & & $43.5^{* * *}$ & $17.6^{* * *}$ \\
Plot & $30.6^{* * *}$ & $23.3^{* * *}$ & & $20.0^{* * *}$ & $17.8^{* * *}$ \\
Dominance $\times$ competition & $13.5^{* * *}$ & $13.1^{* * *}$ & & $4.1 * *$ & $3.3^{* *}$ \\
Competition $\times$ age & 1.0 & 0.8 & & 0.8 & 1.2 \\
\hline
\end{tabular}

${ }^{\text {a }}$ Given are $F$ values and $P$ levels $(* P \leq 0.05, * * P \leq 0.01, * * * P \leq 0.001)$.

Table 3.S4: Mean sensitivity (Sens.) and first-order autocorrelation coefficients (AC) calculated for different time intervals between 1941 and 2010 for selected groups of trees from the forest interior. ${ }^{2}$

\begin{tabular}{|c|c|c|c|c|c|c|c|c|}
\hline & \multicolumn{2}{|c|}{$1941-1961$} & \multicolumn{2}{|c|}{$1962-1981$} & \multicolumn{2}{|c|}{ 1982-1997 } & \multicolumn{2}{|c|}{$1998-2010$} \\
\hline & Sens. & $\mathrm{AC}$ & Sens. & $\mathrm{AC}$ & Sens. & $\mathrm{AC}$ & Sens. & $\mathrm{AC}$ \\
\hline \multicolumn{9}{|c|}{ Very old trees (>160 years): } \\
\hline \multirow[t]{2}{*}{ A } & $0.41 \pm$ & $0.04 \pm$ & $0.29 \pm$ & $0.30 \pm$ & $0.31 \pm$ & $0.40 \pm$ & $0.46 \pm$ & $0.20 \pm$ \\
\hline & $0.01 \mathrm{a}$ & $0.04 \mathrm{~A}$ & $0.01 \mathrm{~b}$ & $0.03 \mathrm{~B}$ & $0.02 \mathrm{~b}$ & $0.02 \mathrm{C}$ & $0.02 \mathrm{c}$ & $0.05 \mathrm{D}$ \\
\hline \multirow[t]{2}{*}{ B } & $0.30 \pm$ & $0.09 \pm$ & $0.22 \pm$ & $0.31 \pm$ & $0.25 \pm$ & $0.34 \pm$ & $0.42 \pm$ & $0.10 \pm$ \\
\hline & $0.04 \mathrm{a}$ & $0.08 \mathrm{~A}$ & $0.03 \mathrm{a}$ & $0.17 \mathrm{~A}$ & $0.04 \mathrm{a}$ & $0.13 \mathrm{~A}$ & $0.05 \mathrm{~b}$ & $0.12 \mathrm{~A}$ \\
\hline \multicolumn{9}{|c|}{ Old trees (101-160 years): } \\
\hline \multirow[t]{2}{*}{$\mathrm{E}$} & $0.52 \pm$ & $0.35 \pm$ & $0.32 \pm$ & $0.51 \pm$ & $0.32 \pm$ & $0.54 \pm$ & $0.45 \pm$ & $0.39 \pm$ \\
\hline & $0.01 \mathrm{a}$ & $0.05 \mathrm{~A}$ & $0.01 \mathrm{~b}$ & $0.03 \mathrm{~B}$ & $0.01 \mathrm{~b}$ & $0.04 \mathrm{~B}$ & $0.02 \mathrm{c}$ & $0.04 \mathrm{~A}$ \\
\hline \multirow[t]{2}{*}{$\mathrm{F}$} & $0.47 \pm$ & $0.35 \pm$ & $0.32 \pm$ & $0.78 \pm$ & $0.28 \pm$ & $0.50 \pm$ & $0.41 \pm$ & $0.44 \pm$ \\
\hline & $0.03 \mathrm{a}$ & $0.09 \mathrm{~A}$ & $0.03 \mathrm{~b}$ & $0.03 \mathrm{~B}$ & $0.02 \mathrm{~b}$ & $0.08 \mathrm{~A}$ & $0.04 \mathrm{a}$ & $0.01 \mathrm{~A}$ \\
\hline \multirow[t]{2}{*}{$\mathrm{G}$} & $0.33 \pm$ & $0.13 \pm$ & $0.22 \pm$ & $0.36 \pm$ & $0.24 \pm$ & $0.27 \pm$ & $0.39 \pm$ & $0.30 \pm$ \\
\hline & $0.02 \mathrm{a}$ & $0.07 \mathrm{~A}$ & $0.01 \mathrm{~b}$ & $0.07 \mathrm{~B}$ & $0.05 \mathrm{~b}$ & $0.02 \mathrm{~B}$ & $0.03 \mathrm{c}$ & $0.05 \mathrm{~B}$ \\
\hline \multicolumn{9}{|c|}{ Middle-aged trees (60-100 years): } \\
\hline \multirow[t]{2}{*}{$\mathrm{H}$} & $0.47 \pm$ & 0.40 & $0.38 \pm$ & $0.46 \pm$ & $0.34 \pm$ & $0.48 \pm$ & $0.42 \pm$ & 0.64 \\
\hline & $0.01 \mathrm{a}$ & $\pm 0.05 \mathrm{~A}$ & $0.01 \mathrm{~b}$ & $0.02 \mathrm{~B}$ & $0.01 \mathrm{c}$ & $0.02 \mathrm{~B}$ & $0.01 \mathrm{~d}$ & $\pm 0.01 \mathrm{C}$ \\
\hline \multirow[t]{2}{*}{ I } & $0.52 \pm$ & 0.45 & $0.37 \pm$ & $0.77 \pm$ & $0.25 \pm$ & $0.36 \pm$ & $0.47 \pm$ & 0.34 \\
\hline & $0.09 \mathrm{a}$ & $\pm 0.09 \mathrm{~A}$ & $0.01 \mathrm{~b}$ & $0.03 \mathrm{~B}$ & $0.01 \mathrm{c}$ & $0.07 \mathrm{~B}$ & $0.04 \mathrm{a}$ & $\pm 0.06 \mathrm{~B}$ \\
\hline \multirow[t]{2}{*}{$\mathrm{J}$} & $0.39 \pm$ & 0.56 & $0.36 \pm$ & $0.43 \pm$ & $0.39 \pm$ & $0.36 \pm$ & $0.39 \pm$ & 0.71 \\
\hline & $0.01 \mathrm{a}$ & $\pm 0.05 \mathrm{~A}$ & $0.01 \mathrm{a}$ & $0.03 \mathrm{~B}$ & $0.02 \mathrm{a}$ & $0.05 \mathrm{~B}$ & $0.02 \mathrm{a}$ & $\pm 0.02 \mathrm{C}$ \\
\hline \multirow[t]{2}{*}{$\mathrm{K}$} & $0.42 \pm$ & 0.39 & $0.37 \pm$ & $0.39 \pm$ & $0.39 \pm$ & $0.30 \pm$ & $0.50 \pm$ & 0.40 \\
\hline & $0.02 \mathrm{a}$ & $\pm 0.05 \mathrm{~A}$ & $0.02 \mathrm{~b}$ & $0.06 \mathrm{~A}$ & $0.02 \mathrm{ab}$ & $0.05 \mathrm{~A}$ & $0.02 \mathrm{c}$ & $\pm 0.04 \mathrm{~A}$ \\
\hline
\end{tabular}

${ }^{\mathrm{a}}$ Within a row, means followed by different letters, differ significantly (Duncan's multiple range test, $P \leq 0.05$ ); separate testing for mean sensitivity (lowercase letters) and autocorrelation (capital letter). 


\section{Funding}

The study was supported by a grant of the Volkswagen Foundation to M.H., C.D. and C.L. for the project 'Forest regeneration and biodiversity at the forest-steppe border of the Altai and Khangai Mountains under contrasting developments of livestock numbers in Kazakhstan and Mongolia'.

\section{Acknowledgments}

We are thankful to the Altai Tavan Bogd National Park for permissions to carry out the field work. B. Jadambaa is thanked for his help during field work. 


\section{References}

Allen, C.D., Macalady, A.K., Chenchouni, H., Bachelet, D., McDowell, N., Vennetier, M., Kitzberger T., Rigling, A., Breshear, D.D., Hogg, E.H., Gonzalek, P., Fensham, R., Zhang, Z., Castro, J., Demidova, N., Lim, J.H., Allard, G., Running, S.W., Semerci, A., Cobb, N., 2010. A global overview of drought and heat-induced tree mortality reveals emerging climate change risks for forests. Forest Ecology and Management 259, 660-684.

Aussenac, G., 2000. Interactions between forest stands and microclimate: ecophysiological aspects and consequences for silviculture. Annals Forest Science 57, 287-301.

Batima, P., Natsagdorj, L., Gombluudev, P., Erdenetsetseg, B., 2005. Observed climate change in Mongolia. Assessments of Impacts and Adaptations of Climate Change, Workings Papers $12,1-26$.

Beket, U., 2009. The vegetation of the Mongolian Altai: problems of sustainable land use and nature Conservation. BfN-Skripten 257, 1-317.

Clarke, K.R., 1993. Non-parametric multivariate analyses of changes in community structure. Australian Journal of Ecology 18, 117-143.

D’Arrigo, R., Jacoby, G., Pederson, N., Frank, D., Buckley, B., Baatarbileg, N., Mijiddorj, R., Dugarjav, Ch., 2000. Mongolian tree-rings, temperature sensitivity and reconstructions of northern hemisphere temperature. Holocene 10, 669-672.

Davi, N., Jacoby, G., Fang, K., Li, J., D’Arrigo, R., Baatarbileg, N., Robinson, D., 2010. Reconstructing drought variability for Mongolia based on a large-scale tree ring network: 1520-1993. Journal of Geophysical Research 115:D22103. doi:10.1029/2010JD013907.

Dulamsuren, Ch., Hauck, M., Bader, M., Osokhjargal, D., Oyungerel, Sh., Nyambayar, S., Runge, M., Leuschner, C., 2009. Water relations and photosynthetic performance in Larix sibirica growing in the forest-steppe ecotone of northern Mongolia. Tree Physiology 29, 99-110.

Dulamsuren, Ch., Hauck, M., Khishigjargal, M., Leuschner, H.H., Leuschner, C., 2010a Diverging climate trends in Mongolian taiga forests influence growth and regeneration of Larix sibirica. Oecologia 163, 1091-1102.

Dulamsuren, Ch., Hauck, M., Leuschner, C., 2010b. Recent drought stress leads to growth reductions in Larix sibirica in the western Khentey, Mongolia. Global Change Biology 16, 3024-3035. 
Dulamsuren, Ch., Hauck, M., Leuschner, H.H., Leuschner, C., 2011. Climate response of tree-ring width in Larix sibirica growing in the drought-stressed forest-steppe ecotone of northern Mongolia. Annals of Forest Science 68, 275-282.

Erdenechuluun, T., 2006. Wood supply in Mongolia: the legal and illegal economies. Mongolia Discussion Papers. Washington, DC: World Bank.

Fang, K., Gou, X., Chen, F., Zhang, F., Li, Y., Peng, J., 2010. Comparisons of drought variability between central High Asia and monsoonal Asia: inferred from tree rings. Frontiers of Earth Science in China 4, 277-288.

Griffin, K., 1995. Poverty and transition to a Market Economy in Mongolia. Basingstoke, UK: Macmillan.

Gunin, P.D., Vostokova, E.A., Dorofeyuk, N.I., Tarasov, P.E., Black, C.C., 1999. Vegetation dynamics of Mongolia. Dordrecht, NL: Kluwer.

Hoch, G., Körner, C., 2003. The carbon charging of pines at the climatic treeline: a global comparison. Oecologia 135, 10-2.

Iwahana, G., Machimura, T., Kobayashi, Y., Fedorov, A.N., Konstantinov, P.Y., Fukuda. M., 2005. Influence of forest clear-cutting on the thermal and hydrological regime of the active layer near Yakutsk, eastern Siberia. Journal of Geophysical Research 110, G02004. doi: 101029/2005JG000039.

Jacoby, G.C., D'Arrigo, R.D., Davaajamts, T., 1996. Mongolian tree-rings and $20^{\text {th }}$-century warming. Science 273, 771-773.

Kenneth, M., Hinkel, K.M., Nicholas, R.J., 1995. Active layer thaw rate at a boreal forest site in central Alaska, USA. Arctic and Alpine Research 27, 72-80.

Kirdyanov, A., Hughes. M., Vaganov, E., Schweingruber, F., Silkin, P., 2003. The importance of early summer temperature and date of snow melt for tree growth in the Siberian Subarctic. Trees 17, 61-69.

Körner, C., Sarris, D., Christodoukalis, D., 2005. Long-term increase in climatic dryness in the East-Mediterranean evidenced for the island of Samos. Regional Environmental Change 5, 27-36.

Kushlin, A., Schillhorn van Veen, T., Sutton, W., 2004. Kazakhstan: Forest sector in Transition. The resource, the users and sustainable use. Technical Paper. Washington, DC: World Bank. 
Lkhagvadorj, D., Hauck, M., Dulamsuren, Ch., Tsogtbaatar, J., 2013. Pastoral nomadism in the forest-steppe of the Mongolian Altai under a changing economy and a warming climate. Journal of Arid Environments 88, 83-89.

Li, J., Cook, E.R., D’Arrigo, R., Chen, F., Gou, X., 2009. Moisture variability across China and Mongolia. Climate Dynamics 32, 1173-1186.

Li, S-G., Tsujimura, M., Sugimoto, A., Sasaki, L., Yamanaka, T., Davaa, G., Oyunbaatar, D., Sugita, M., 2006, Seasonal variation in oxygen isotope composition of waters for a montane larch forest in Mongolia. Trees 20, 122-130.

Li, S-G., Romero-Saltos, H., Tsujimura, M., Sugimoto, A., Sasaki, L., Davaa, G., Oyunbaatar, D., 2007. Plant water sources in the cold semiarid ecosystem of the upper Kherlen river catchment in Mongolia: a stable isotope approach. Journal of Hydrology 333, 109-117.

Nandintsetseg, B., Greene, J.S., Goulden, C.E., 2007. Trends in extreme daily precipitation and temperature near Lake Hövsgöl, Mongolia. International Journal of Climatology 27, 341347.

Nikolaev, A.N., Fedorov, P.P., Desyatkin, A.R., 2009. Influence of climate and soil hydrothermal regime on radial growth of Larix cajanderi and Pinus sylvestris in Central Yakutia, Russia. Scandinavian Journal of Forest Research 24, 217-226.

Ovchinnikov, D.V., 2002. Reconstruction of summer air temperature and ablation of Maliy Aktru Glacier. Izvestiya Rossiskaya Akademiya Nauk, Seriya Geograficheskaya 5, 91-96.

Rudaya, N.A., Tarasov, P.E., Dorofuyek, N.I., Kalugin, I.A., Andreev, A.A., Diekmann, B., Daryin, A.V., 2008. Environmental changes in the Mongolian Altai during the Holocene. Archaeology, Ethnology and Anthropology of Eurasia 36, 2-14.

Sala, A., Hoch, G., 2009. Height-related growth declines in ponderosa pine are not due to carbon limitation. Plant, Cell and Environment 32, 22-30.

Sala, A., Woodruff, D.R., Meinzer, F.C., 2012. Carbon dynamics in trees: feast or famine? Tree Physiology 32, 764-775.

Sankey, T.T., Montagne, C., Graumlich, L., Lawrence, R., Nielsen, J., 2006. Lower forestgrassland ecotones and 20th century livestock herbivory effects in northern Mongolia. Forest Ecology and Management 233, 36-44.

Schlütz, F., Lehmkuhl, F., 2007. Climatic change in the Russian Altai, southern Siberia, based on palynological and geomorphological results with implications on climatic teleconnections 
and human history since the middle Holocene. Vegetation History and Archaeobotany 16, 101-18.

Sharkhuu, N., Sharkhuu, A., 2012. Effects of climate warming and vegetation cover on permafrost of Mongolia. In Werger MJA, van Staalduinen MA (eds). Ecological Problems and Livelihoods in a Changing World. Dordrecht: Springer, 445-72.

Sneath, D., 2004. Proprietary regimes and sociotechnical systems: rights over land in Mongolia's 'Age of the Market'. In Verdery K, Humphrey C (eds) Property in question: value transformation in the global economy, Oxford: Berg, 161-182.

Sugimoto, A., Yanagisawa, N., Naito, D., Fujita, N., Maximov, T.C., 2002. Importance of permafrost as a source of water for plants in east Siberian taiga. Ecological Research 17, 493-503.

Tarasov, P., Jin, G., Wagner, M., 2006. Mid-Holocene environmental and human dynamics in northeastern China reconstructed from pollen and archaeological data. Palaeogeography, Palaeoclimatology, Palaeoecology 241, 284-300.

Tarasov, P., Williams, J.W., Andreev, A., Nakagawa, T., Bezrukova, E., Herzschuh, U., Igarashi, Y., Müller, S., Werner, K., Zheng, Z., 2007. Satellite- and pollen-based quantitative woody cover reconstructions for northern Asia: verification and application to late-Quaternary pollen data. Earth and Planetary Science Letters 264, 284-98.

Wigley, T.M.L., Briffa, K.R., Jones, P.D., 1984. On the average value of correlated time series, with applications in dendroclimatology and hydrometeorology. Journal of Climate and Applied Meteorology 23, 201-13.

Yatagai, A., Yasunari, T., 1995. Interannual variations of summer precipitation in the arid/semiarid regions in China and Mongolia: their regionality and relation to the Asian summer monsoon. Journal of the Meteorological Society of Japan 73, 909-23. 


\section{CHAPTER}

4

\section{CONTRASTING RESPONSES OF SEEDLING AND SAPLING DENSITIES TO LIVESTOCK DENSITY IN THE MONGOLIAN FOREST-STEPPE}

Mookhor Khishigjargal, Choimaa Dulamsuren, Dorjburgedaa Lkhagvadorj, Christoph Leuschner and Markus Hauck

Submitted to Plant Ecology 


\begin{abstract}
The past and present regeneration of Siberian larch (Larix sibirica) was studied in the forest-steppe of the Mongolian Altai, an area which has experienced an increase in annual mean temperature by $2.1{ }^{\circ} \mathrm{C}$ since 1940 and is subjected to grazing by mixed herds of livestock owned by pastoral nomads. Past regeneration was reconstructed from tree rings and present regeneration was analyzed by surveying seedlings, sapling-sized trees and the occurrence of viable larch seeds in the soil seed bank. Forest regeneration occurred throughout the $20^{\text {th }}$ and the early 21 st centuries in the forest interiors, but ceased after the late 1970s at forest edges. The density of larch sapling-sized trees decreased with livestock density linearly in the interior and exponentially at the edge. Most sapling-sized trees had visible damage from livestock browsing, which also manifested in woodanatomical anomalies. By contrast, the densities of 1- and 2-yr old seedlings increased with livestock density at the forest edge, suggesting that seedlings in this habitat benefitted from the reduction in competition intensity due to livestock grazing. This relationship also suggests that larch seedlings, in contrast to sapling-sized trees, were avoided by the livestock, as otherwise removal by the herbivores should have counteracted the promotion due to reduced competition. Near-consistency of the correlations of total livestock and goat densities with sapling and seedling densities suggests that the control of larch regeneration is primarily a function of goat density, which have tripled in the Mongolian livestock during the past 20 years for economic reasons.
\end{abstract}

Keywords: Forest regeneration, tree establishment, herbivory, goats, forest grazing, climate warming 


\subsection{Introduction}

Forests in Central Asia are currently subjected to increasing temperatures and changed land use patterns at many places (Tsogtbaatar, 2004). The productivity of boreal forests is promoted by climate warming at many high-latitude and high-altitude sites in the northern hemisphere (D'Arrigo et al., 2000; Keyser et al., 2000). This includes the high-elevation conifer forests (at c. 2000-2500 m a.s.1.) of the Mongolian Altai, which belong to the southernmost occurrences of Eurosiberian taiga forests (Dulamsuren et al., 2013a). Other boreal forests at the southern fringe of the Eurosiberian taiga in Central Asia, in contrast, have declined in productivity because rising temperatures, in several places reinforced by decreasing precipitation, have increased drought stress (Dulamsuren et al., 2010, 2013b). While most forests in the circumboreal vegetation belt are either remaining pristine old-growth stands or, more widespread, used for industrial logging (Östlund et al., 1997; Luyssaert et al., 2008), many forests in Central Asia, in the transition of the Eurosiberian taiga to the Eurasian steppe, are subjected to various kinds of utilization by the local population, including unsystematic timber harvest, fuel-wood collection, the collection of fruits and medicinal herbs, and forest grazing (Lkhagvadorj et al., 2013a). In comparison with the effects of climate warming, the impact of the widespread wood and non-wood forest use in the Central Asian forest-steppe ecotone is less intensely studied.

In the Mongolian Altai, Dulamsuren et al. (2013a) showed that warming by $0.5{ }^{\circ} \mathrm{C}$ per decade since 1940 stimulated the radial stem increment in the dominant tree species, Siberian larch (Larix sibirica Ledeb.). However, changed land-use practices of the pastoral nomads residing in the Mongolian Altai counteracted this gain in productivity. Changes in the socio-political framework associated with the transition from planned to market economy in the early 1990s and the extension of the snow-free period resulted in reduced mobility of the pastoralists (Lkhagvadorj et al., 2013a). The longer annual residence time near the forests, combined with an increased demand for construction and fuel wood due to altered customs, led to the rapid and unsustainable increase of logging activities, which could be traced by tree-ring analysis and analysis of the stand structure (Dulamsuren et al., 2013a).

In the present paper, we were interested in how forest grazing influences the larch forests of the forest-steppe of the Mongolian Altai. Ecological effects of forest grazing have been extensively studied in selected regions of Central Asia (especially Kyrgyzstan; Buttoud and 
Yunusova, 2002) and Southern Asia (especially Bhutan; Buffum et al., 2009), but have been little addressed in Mongolia (Sankey et al., 2006; Ishii and Fujita, 2013), although pastoral livestock keeping is widespread in the forest-steppe and is an important branch of the Mongolian economy (Janzen 2005). Relevant studies are scarce despite of a strong increase in the number of cashmere goats in the Mongolian livestock (Fernández-Giminéz et al. 2012), which graze the vegetation more thoroughly and cause more damage in woody plants than other species of livestock (Hughes and Thirgood, 1982; Fujita et al., 2013). In contrast to logging, livestock grazing is primarily affecting forest regeneration. We therefore analyzed the present and past regeneration of Siberian larch forests in the Mongolian Altai, assessed the damage of seedlings and sapling-sized trees by livestock grazing and related the present seedling and sapling density to the density of livestock around the sample plots. With our investigation, we tested the hypotheses that (1) the present climate is not a major constraint for tree regeneration in the Mongolian Altai and (2) the density of tree seedlings and sapling-sized trees decreases with increasing livestock density.

\subsection{Materials and methods}

\subsubsection{Study area}

Field research was carried out in the Mongolian Altai in the Altai Tavan Bogd National Park in the administrative subunit Dayan ( $\left.48^{\circ} 27^{\prime} \mathrm{N}, 88^{\circ} 90^{\prime} \mathrm{E}\right), 110 \mathrm{~km}$ southwest of the capital city Ulgii of the Bayan-Ulgii province (Fig. 4.1). Dayan is located at relatively high elevation (above $2000 \mathrm{~m}$ a.s.1.). The vegetation consists of a mosaic of conifer forests at c. 2000-2500 m a.s.1. on northfacing slopes and at the flanks of the central central chain of high peaks of the Mongolian Altai (up to $4734 \mathrm{~m}$ a.s.1) as well as grasslands in the valleys, on south-facing slopes and above the alpine treeline. Most forests are dominated by Siberian lach (Larix sibirica). Siliceous rock, including granite and schist, is the dominant bedrock. The prevailing forest soils are Leptosols under continuous permafrost influence (Sharkhuu and Sharkuu, 2012). The forest-steppe of the Dayan area is inhabited by more than 80 families of pastoral nomads during summer, which house in the valleys in front of the forests (Lkhagvadorj et al., 2013a). Some of the families stay in the area 
whole year. The nomads keep sheep, goats, yaks, horses, and few camels, which are all not or little herded and graze in both the grasslands and the forests.

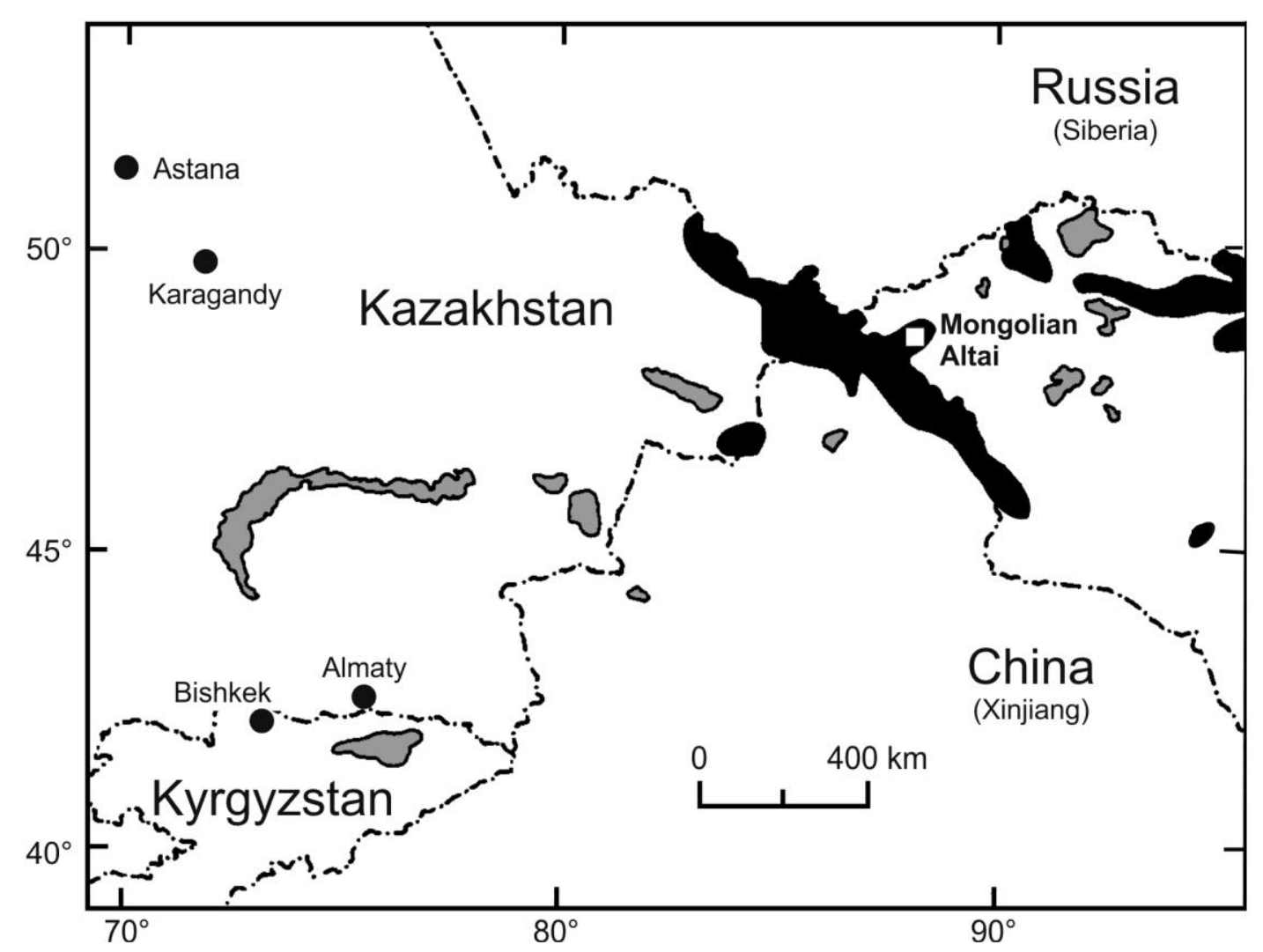

Fig. 4.1. Location of the study area in the Mongolian Altai in westernmost Mongolia. Black areas represent the distribution of $L$. sibirica forests (distribution in Russia where $L$. sibirica occurs everywhere within the map section is not shown). Gray areas are lakes

\subsubsection{Climate}

Climate data from the study area since 1940 were recently analyzed by Dulamsuren et al. (2013a) using instrumental data from the weather station Altai-Yalalt $\left(48^{\circ} 17^{\prime} \mathrm{N}, 89^{\circ} 31^{\prime} \mathrm{E}, 2150 \mathrm{~m}\right.$ a.s.1., 40 $\mathrm{km}$ east of Dayan for the period 1970-2010. This data were extended by calculated values from 1940-1969 using linear regression analysis and weather data from the weather station in Ulgii City (1960 m a.s.1.). Temperature is Dayan is overestimated by c. $1{ }^{\circ} \mathrm{C}$ and precipitation is underestimated compared to Altai-Yalalt, as the elevation of the latter is $150 \mathrm{~m}$ below that of Dayan. Annual, July, and January temperatures between 1940 and 2010 were $-3.4{ }^{\circ} \mathrm{C}, 12.9{ }^{\circ} \mathrm{C}$, and 
$-21.2{ }^{\circ} \mathrm{C}$, respectively. Annual mean temperature has increased by $2.1^{\circ} \mathrm{C}(P<0.001)$ in this period. Annual precipitation $(120 \mathrm{~mm}$ ) has remained constant; it is highly variable between years (range $78-211 \mathrm{~mm}$ ) and has a clear peak from June to August (54\% of the annual precipitation).

\subsubsection{Sample plot design}

Field work was carried out in July 2010. Six forested sites (monospecific L. sibirica forests) were selected on the northern flank of a mountain ridge located 2 to $7 \mathrm{~km} \mathrm{~S}$ and SSE of Lake Dayan Nuur $\left(48^{\circ} 23^{\prime} \mathrm{N}, 88^{\circ} 55^{\prime} \mathrm{E}\right)$. Site selection included all available forest islands on the studied mountain range; thus the selection procedure largely excluded the subjective choice of sites. Relatively moist depressions, which occur locally on the mountain slopes, were deliberately avoided to improve the comparability between the sites. The distance between neighboring sites amounted to $2.2 \pm 0.5 \mathrm{~km}$. At each site, four plots each of $20 \mathrm{~m} \times 20 \mathrm{~m}$ size were selected. One of them was located at the forest edge with the lower boundary of the plot being identical with the forest line to the steppe. The three other plots were located at 50 to $100 \mathrm{~m}$ distance from the edge in direction of the forest interior. The distance of the three interior plots to one another was ca. 20 $\mathrm{m}$; these three plots were statistically not independent and should provide a broader basis for the data from the forest interior. The plots were located between 2300 and $2440 \mathrm{~m}$ a.s.1.

\subsubsection{Reconstructing past tree establishment from tree rings}

Tree-ring data were used to reconstruct past tree establishment. Wood cores from all trees with a diameter at breast height $(\mathrm{DBH})>3 \mathrm{~cm}$ growing in the sample plots were collected at breast height using an increment borer with an inner diameter of $5 \mathrm{~mm}$. The borer was driven into the wood parallel to the contour lines of the slope. In this way, a total of 1826 larch trees were sampled (220379 trees per site). Stand density varied between 525 and 2950 trees $^{-1}$ as did the stem basal area between 14 and $58 \mathrm{~m}^{2} \mathrm{ha}^{-1}$ (Table 4.1). In addition, tree stump density was assessed by counting; it varied between 450 and 4500 stumps ha $^{-1}$ (Table 4.1). In the laboratory, wood cores were mounted on grooved wooden strips and cut lengthwise by hand using scalpels. The contrasts between annual 
tree-rings were enhanced with chalk. Data recording and evaluation were conducted with TSAP (Time Series Analysis and Presentation)-Win software (Rinntech, Heidelberg, Germany). Annual tree-ring width was measured with a precision of $10 \mu \mathrm{m}$ on a movable object table (Lintab 5). The quality of the measurements was controlled and missing rings were detected by crossdating among others by identifying local pointer years. Crossdating was based on the use of two parameters: coefficient of agreement ('Gleichläufigkeit' [GL]) (Eckstein \& Bauch, 1969) and (standard) $t$ values. The $G L$ - and $t$-values measure the similarity between tree-ring series in the high- and lowfrequency domain, respectively. The years of establishment (i.e., germination) of the individual trees were inferred from wood core samples taken at $1.3 \mathrm{~m}$ above the ground by adding 10 years to the number of tree rings counted (cambium age at breast height) (Körner et al., 2005; Sankey et al., 2006). The reconstruction of tree establishment from tree-ring series was restricted to the period 1900-2010, since the information for older trees is too incomplete because many trees of that age are likely to have already died from natural mortality or have been felled. The oldest larch trees on the sample plots were >300 years old (Dulamsuren et al., 2013a).

Table 4.1. Stand characteristics and livestock densities of the six sites in the forest interior and at the forest edge

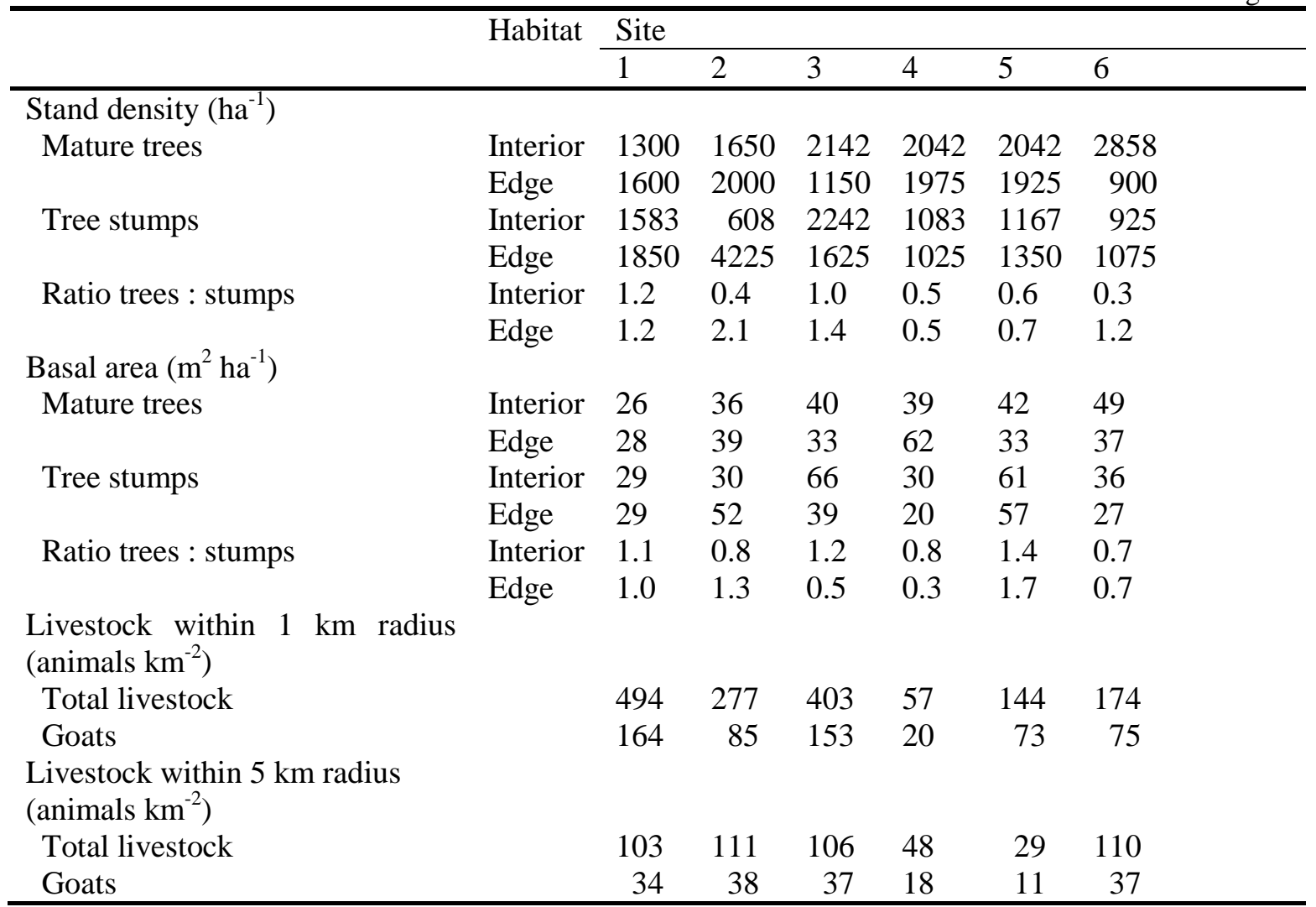




\subsubsection{Survey of sapling numbers, age and grazing damage}

Trees with a DBH $\leq 3 \mathrm{~cm}$ (and height $\leq 4 \mathrm{~m}$ ) are defined as 'saplings', or more precisely 'saplingsized trees' because many trees of this age were several decades old, throughout the paper, whereas trees with larger stem diameter are termed 'mature trees'. Larch saplings were grouped in five height classes $(\leq 0.5,0.6-1,1.1-2,2.1-3,3.1-4 \mathrm{~m})$ and counted. Moreover, browsing damage was assessed for every sapling-sized trees in the field by estimating the degree of defoliation in six classes, viz. class 0, no damage (defoliation $0 \%$ ); class 1, 1-25\% defoliated; class 2, 26-50\% defoliated; class 3, 51-75 \% defoliated; class 4, 76-99 \% defoliated; class 5, dead (defoliation 100 $\%$, tree dry). In each plot, randomly selected sapling-sized trees of each height class were harvested for collecting a stem cross-section above the root collar; totally 521 cross-sections were collected. The cross-sections were prepared with scalpels to count rings with the Lintab 5 measuring table and TSAP software as described for the wood cores. However, some crosssections were too small or the rings were too narrow for proper identification with this method. For these samples, we prepared microtome sections, which were stained with Euparal solution, and counted the rings using a Stereo Discovery V20 compound microscope (Carl Zeiss, Jena, Germany) at a magnification of up to $60 \times$. Cross-sections of 235 randomly selected sapling-sized trees were analyzed for the frequency of wood-anatomical anomalies under the compound microscope. In particular, we controlled the samples for wedging rings (i.e. the tree ring is not formed over the whole stem circumference due to local injury) and reaction wood (i.e. additional wood that is formed at one side of the stem to compensate for alterations in the stem position, e.g., after the sapling was stamped down by livestock) (Schweingruber et al., 2006).

\subsubsection{Assessing seedling numbers and survival}

In every forest-edge plot and in one plot in the forest interior per site, five $1 \mathrm{~m} \times 1 \mathrm{~m}$ subplots were randomly selected to count seedlings. One-year old or older seedlings were counted separately. Counting in the same subplots was done in summer 2010 and repeated in summer 2011 to assess seedling survival over winter. 


\subsubsection{Analyzing relationships of sapling and seedling density and vitality with livestock densities}

The pastoralists' livestock in the study area is free-roaming and grazes in mixed herds on common pasture (Lkhagvadorj et al., 2013a). It is therefore not possible to assessed fixed stocking rates of livestock for individual areas. Rather, we recorded the geographical position of 82 nomad camps during summer 2010 and surveyed the numbers of livestock kept by the individual families in herder interviews (Lkhagvadorj pers. comm.). These data were used to calculate livestock densities (Table 1) in a radius of $1 \mathrm{~km}$ or $5 \mathrm{~km}$, respectively, from the sample plots following Hauck and Lkhagvadorj (2013). These livestock densities were correlated with seedling and sapling numbers of different height and vitality. The position of the pastoralists' campsites in the Mongolian foreststeppe is remarkably stable across consecutive years (Lkhagvadorj et al., 2013a, b).

\subsubsection{Soil seed bank}

The seed bank of Siberian larch in the sample plots was studied by sampling of the soil organic layer (upper $5 \mathrm{~cm}$ or less if thinner) in randomly selected subplots of $10 \mathrm{~cm} \times 10 \mathrm{~cm}$. Five of these subplots were studied in each forest-edge plot and in one forest-interior plot per site. Seeds were separated from the soil and plant roots in the field. Broken or empty seed capsules were separately counted. Visually intact seeds were taken to the laboratory. To break dormancy, seeds were kept in moist sand at $4{ }^{\circ} \mathrm{C}$ in the dark for 4 weeks. Afterwards seeds were put on filter papers in Petri dishes with nutrient solution (Evans and Nason, 1953). The Petri dishes were stored in a growth chamber and exposed to a relative humidity of $60 \%$ at $20{ }^{\circ} \mathrm{C}$ and a photosynthetic photon flux density (PPFD) of $300 \mu \mathrm{mol} \mathrm{m}-2 \mathrm{~s}-1$ at day time $(13 \mathrm{~h})$ and $15^{\circ} \mathrm{C}$ at night time. The samples were kept in the growth chamber for 16 days and germinated seeds were counted daily. 


\subsubsection{Statistics}

Arithmetic means \pm standard errors are presented throughout the paper. Data were tested for normality with the Shapiro-Wilk test. The Mann-Whitney $U$-test was used for pairwise comparison of not normally distributed data. These analyses were conducted with SAS 9.13 software (SAS Institute Inc., Cary, North Carolina, U.S.A.). Linear regressions and non-linear regressions using a model for exponential decline were calculated with Xact 8.03 software (SciLab, Hamburg, Germany). The $\alpha$-level is 0.05 , but given the small sample size of $N=6, P$ values $>0.05$, but $\leq 0.10$ are considered as 'marginally significant'.

\subsection{Results}

\subsubsection{Tree establishment between 1900 and 2010}

Based on the tree-ring data, there was a striking difference in the recent tree establishment between the forest interior and the forest edge, as the successful establishment of larch trees ended at the forest edge in the mid 1970s, whereas it continued until present in the forest interior (Fig. 4.2). In contrast to the forest edge, tree establishment was frequent in the forest interior also in recent decades. Remarkably, sapling-sized trees with a $\mathrm{DBH} \leq 3 \mathrm{~cm}$ were not necessarily younger than trees with a DBH >3 cm established between 1900 and 2010. Parts of the sapling-sized trees established as early as in the 1910s at the forest edge and in the 1920s in the forest interior. Among the trees that have established between the 1930s and the 1980s, the number of sapling-sized individuals exceeds that of mature trees, i.e. many trees had not reached mature size. 


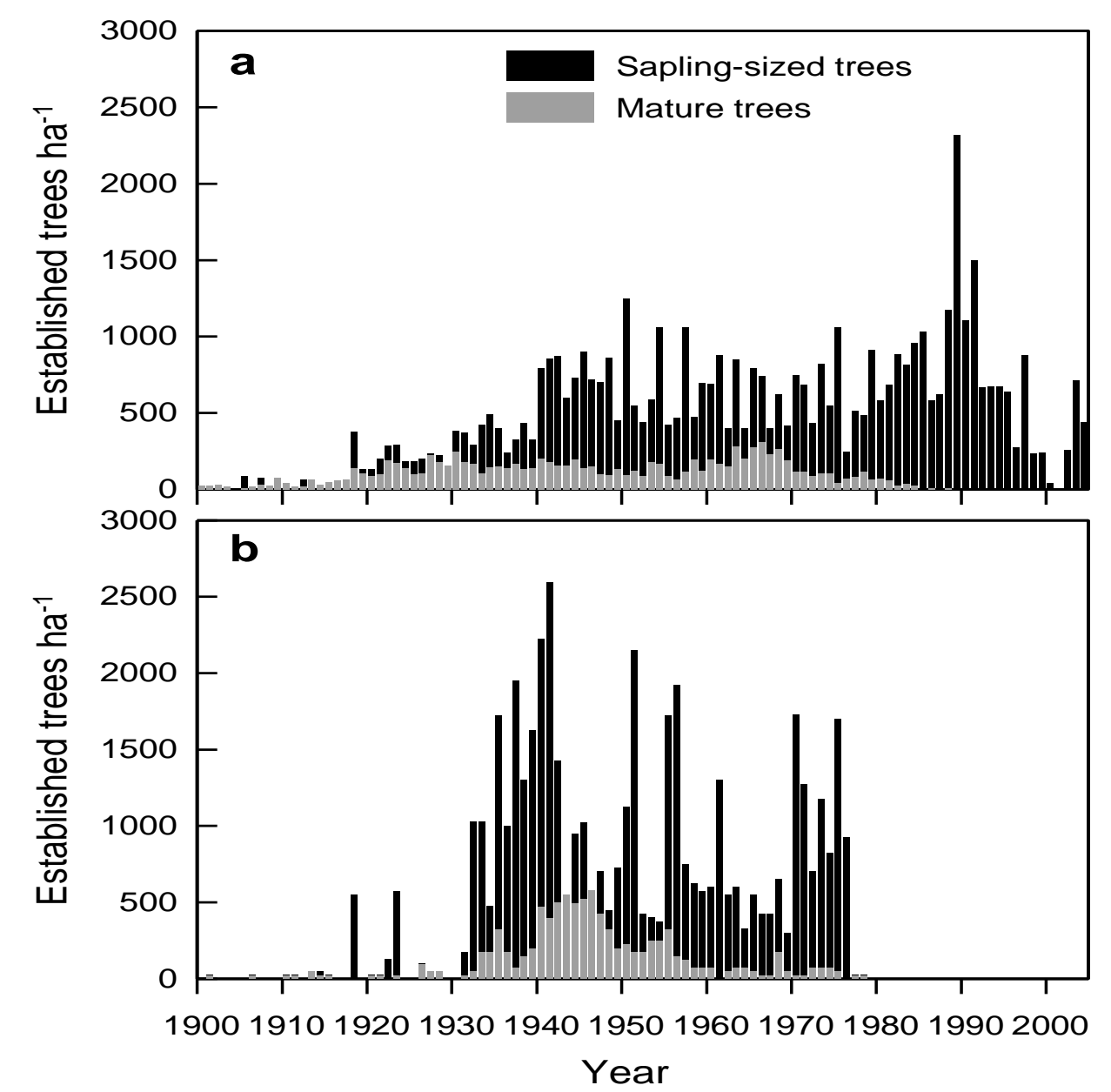

Fig.4.2. Years of establishment of the present $L$. sibirica populations (a) in the forest interior and (b) at the forest edge, including live and dead mature trees (DBH $>3 \mathrm{~cm}$ ) and sapling-sized trees $(\mathrm{DBH} \leq 3 \mathrm{~cm}$ )

Live sapling-sized trees occurred with a higher density in the forest interior than at the forest edge (Table 4.2). About $7 \%$ of the live saplings in the interior, but only $3 \%$ at the edge, were completely undamaged. The number of undamaged sapling-sized trees in the interior exceeded that at the edge by the factor of 2.7. In both habitats, two thirds of the live sapling-sized trees showed moderate defoliation by livestock browsing of up to $50 \%$. In $13 \%$ of the sapling-sized trees of either habitat, defoliation was between 51 and $75 \%$. Heavy damage (76-99\% defoliation) was found in $16 \%$ (interior) and $20 \%$ (edge) of the saplings. Up to $75 \%$ of defoliation, sapling-sized trees showed a trend for higher abundance in the interior than at the edge $(P<0.10)$, whereas it was the other way round for sapling-sized trees with heavy defoliation (76-99\%). 
Table 4.2. Sapling numbers $( \pm$ SE, followed by minimum and maximum values in brackets) of different damage classes in the forest interior and at the forest edge

\begin{tabular}{llll}
\hline Damage class $^{\mathrm{a}}$ & \multicolumn{2}{l}{ Saplings $\left(\mathrm{ha}^{-1}\right)$} & \multirow{2}{*}{$P^{\mathrm{b}}$} \\
\cline { 2 - 3 } & Interior & Edge & 0.04 \\
\cline { 1 - 3 } $1-25 \%$ & $458 \pm 100$ & $167 \pm 115$ & \\
& $(217-908)$ & $(0-675)$ & 0.09 \\
$26-50 \%$ & $2147 \pm 833$ & $1842 \pm 1609$ & \\
& $(675-4792)$ & $(0-9850)$ & 0.06 \\
$51-75 \%$ & $2392 \pm 688$ & $2196 \pm 1724$ & \\
& $(408-5342)$ & $(0-10750)$ & 0.07 \\
$76-99 \%$ & $883 \pm 247$ & $825 \pm 680$ & \\
& $(167-1808)$ & $(0-4200)$ & 0.09 \\
Sum live saplings & $1131 \pm 221$ & $1233 \pm 999$ & \\
& $(558-2017)$ & $(0-6175)$ & 0.05 \\
Dead saplings & $7011 \pm 1586$ & $6263 \pm 5054$ & \\
& $(3033-14017)$ & $(0-31300)$ & \multirow{2}{*}{0.09} \\
\hline
\end{tabular}

${ }^{\mathrm{a}}$ Percentage of defoliation by browsing

${ }^{\mathrm{b}}$ Result of $U$-test

Sapling numbers strongly varied between the individual study sites. While there was a minimum sapling density of 3033 individuals' $\mathrm{ha}^{-1}$ in the forest interior, there was a site without any live sapling-sized trees at the forest edge. In addition to defoliation, sapling-sized trees often suffered from injuries of the wood (Fig. 4.3a, b). 

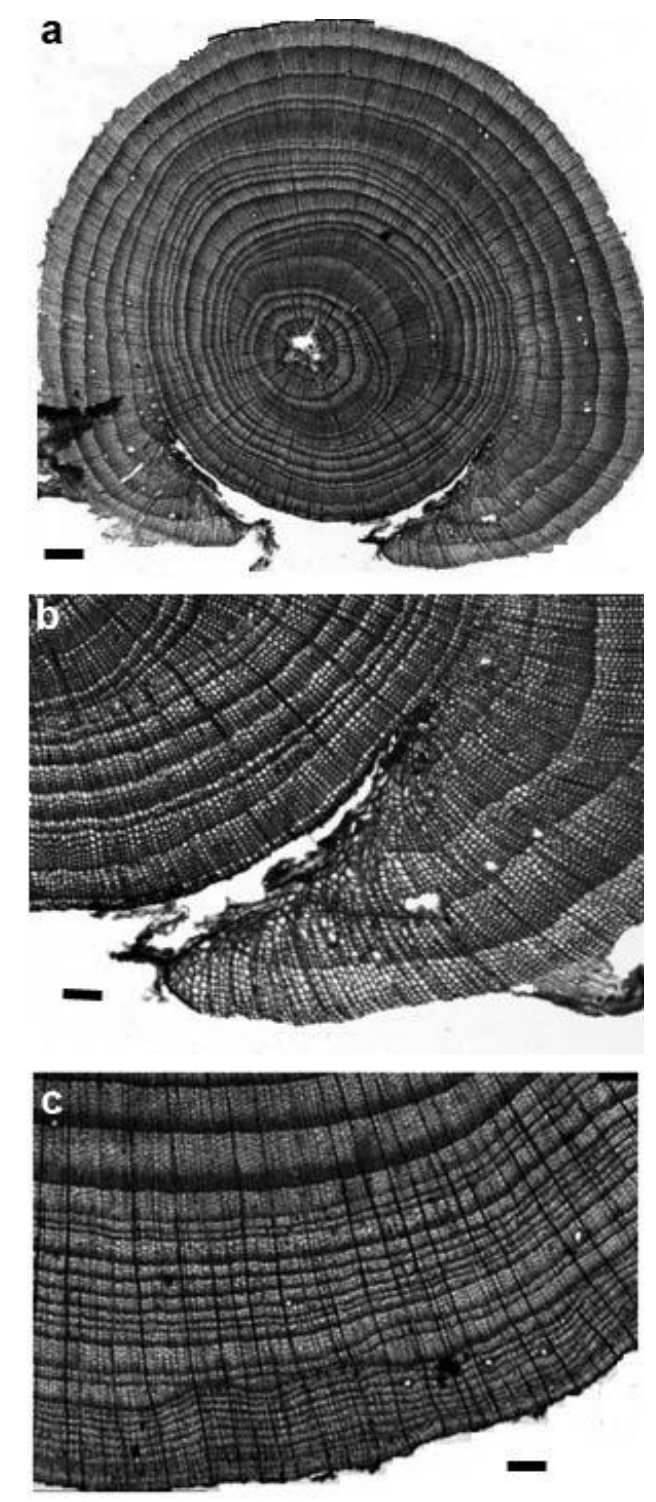

Fig. 4.3. Examples of wood-anatomical anomalies in stem cross-sections of L. sibirica sapling-sized trees: (a) unclosed injury due to browsing, (b) enlarged section of (a), (c) narrow and wedging rings. Bars represent (a) $250 \mu \mathrm{m}$, (b, c) $100 \mu \mathrm{m}$.

These injuries were usually several years to a few decades old. Wedging rings (Fig. 4.3c), where a tree ring is not formed around the full stem circumference, and reaction wood were also frequently found. The frequency of wedging rings has strongly increased in the forest interior (Fig. 4.4a; $r=0.62, P<0.001$ for linear regression) and even more at the forest edge (Fig. 4.4b; $r=0.91$, $P<0.001)$ since c. 1990 . The frequency of reaction wood has also increased in both the interior (Fig. 4.4c; $r=0.80, P<0.001$ ) and the edge (Fig. 4.4d; $r=0.77, P<0.001$ ). 

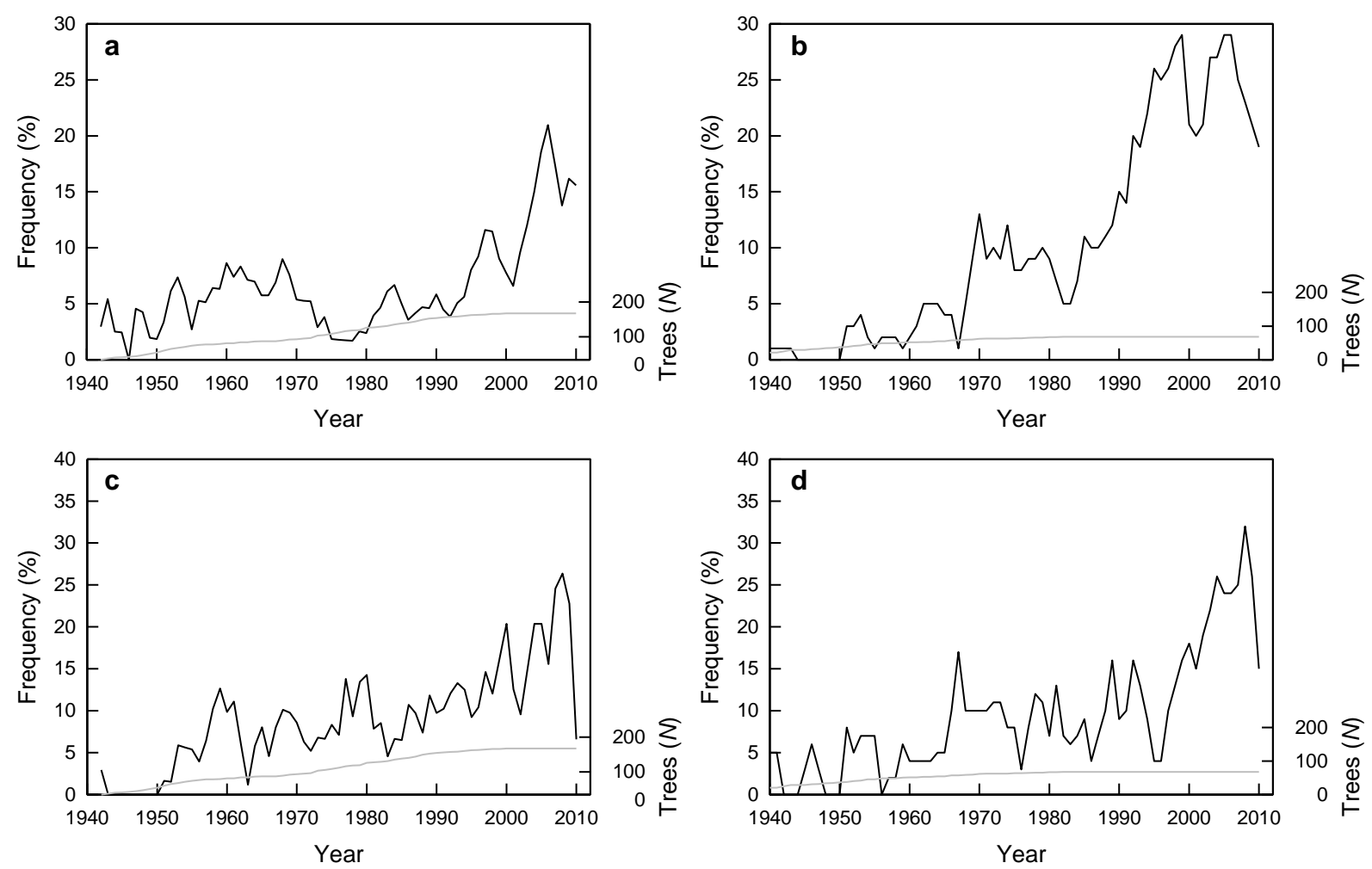

Fig. 4.4. Frequency of $(a, b)$ wedging rings and $(c, d)$ reaction wood in sapling-sized trees from the $(a, c)$ interior and (b, d) edge of larch forests. Percentages refer to the number of sapling-sized trees available in the relevant year

Height classes were increasingly occupied by fewer tree individuals with increasing tree height (Fig. 4.5a). While this result comes up to expectations, it is remarkable that the lack of regeneration after the 1970s at the forest edge (Fig. 4.2b) did not result in fewer small-sized saplings at the edge than in the interior (Fig. 4.5a) giving evidence of the weak or missing heightage and diameter-age relationships, which are already inferable from Fig. 4.2. Trees with a height between 2 and $4 \mathrm{~m}$ were virtually absent from the forest edge (Fig. 4.5a). The relative frequency of damage classes was remarkably stable across height classes (Fig. 4.6). Less than $10 \%$ of the sapling-sized trees were devoid of any browsing damage. While $8 \%$ of the saplings in the lowest height class $(\leq 0.5 \mathrm{~m})$ were undamaged in the interior, there were no undamaged sapling-sized trees of this height class at the edge. Damage distribution for saplings $>2 \mathrm{~m}$ from the forest edge has little meaning because of the rarity of individuals of this height. 

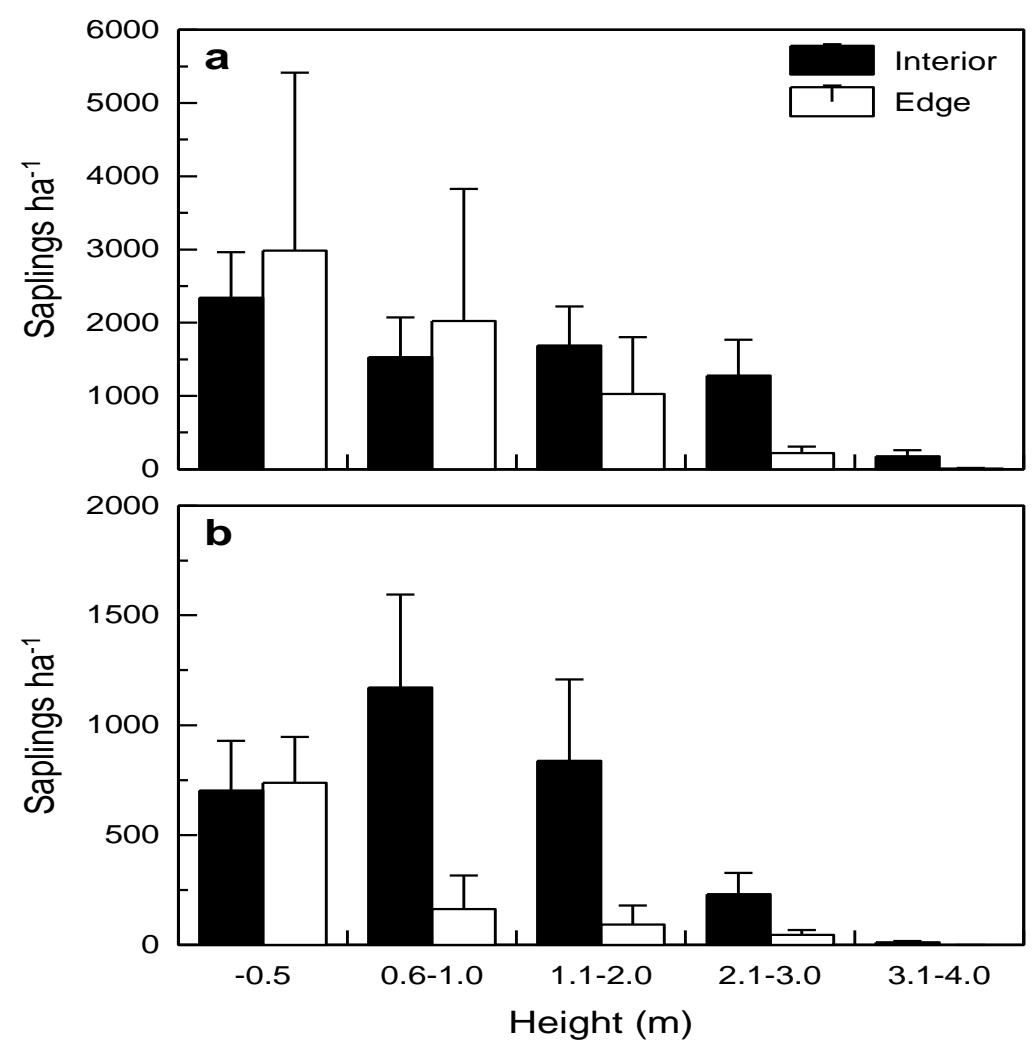

Fig. 4.5. Distribution of (a) live and (b) dead sapling-sized trees in different tree height classes in the forest interior and at the forest edge

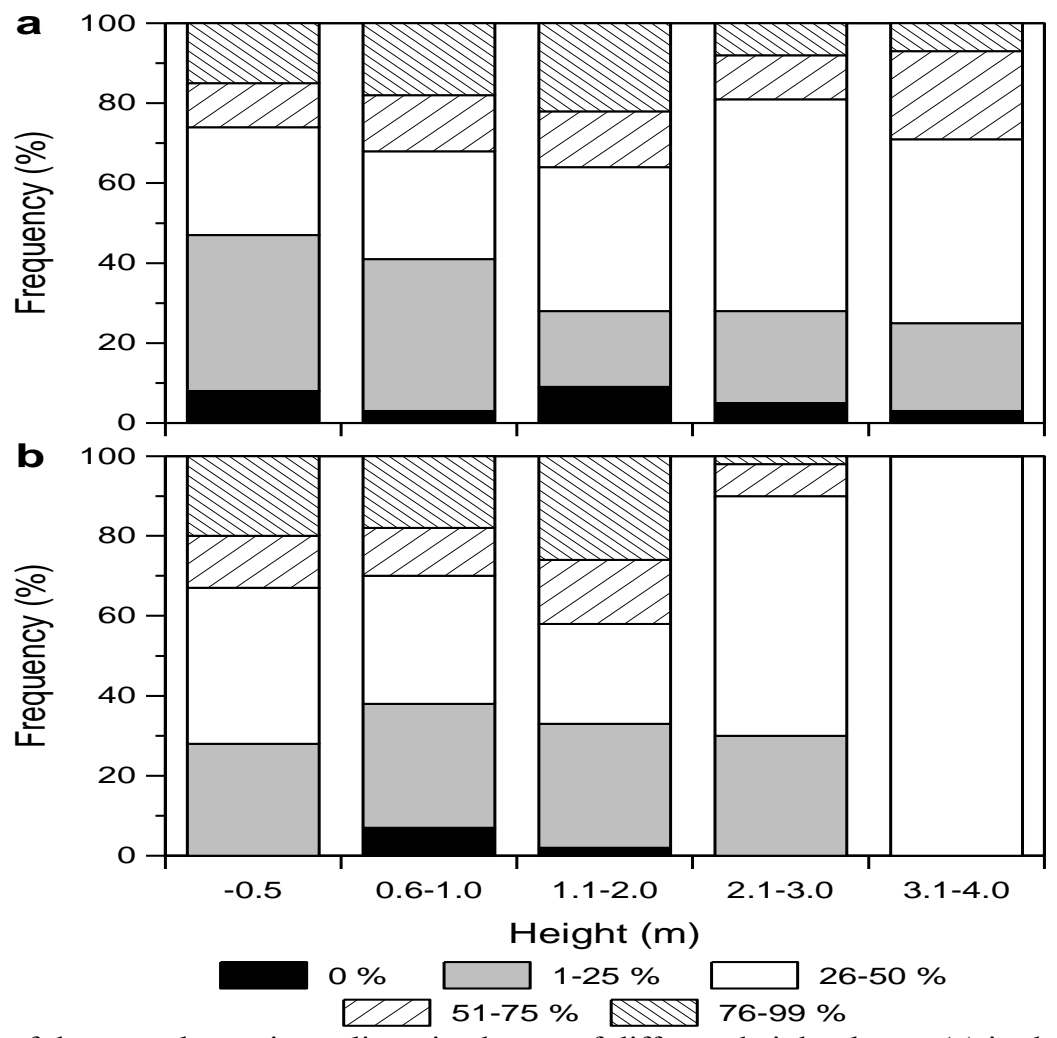

Fig. 4.6. Relative frequency of damage classes in sapling-sized trees of different height classes (a) in the forest interior and (b) at the forest edge 
In addition to the live sapling-sized trees, nearly 3000 dead sapling-sized trees per ha occurred in

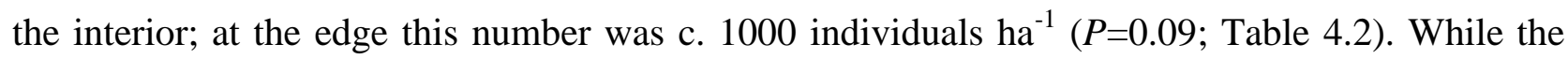
density of dead sapling-sized trees of $\leq 0.5 \mathrm{~m}$ height was the same in the interior and at the edge, much more dead sapling-sized trees of 0.6-2.0 m height occurred in the interior than at the edge (Fig. 4.5b).

\subsubsection{Correlations between browsing damage in saplings and livestock density}

The density of sapling-sized trees decreased with livestock density, with the densities of total livestock (including goats, sheep, yaks, horses, camels) and goats alone yielding very similar correlations with sapling density (Table 4.3; Fig. 4.7a,b). Sapling-sized trees at the forest edge responded more sensitively to increasing livestock density than saplings in the forest interior (Fig. 4.7).

At the edge, sapling density followed an exponential decline with increasing livestock density, whereas this decline was linear in the interior. For strongly damaged saplings (defoliation $>50 \%$ ) and dead sapling-sized trees, no significant correlation was found with livestock density in the forest interior (Table 4.3; Fig. 4.7e, f). The densities of moderately to severely damaged saplings (defoliation $>25 \%$ ) and dead saplings were correlated with the livestock densities within $1 \mathrm{~km}$ radius from the investigated forests (Table 4.3). By contrast, the density of undamaged seedlings decreased with livestock densities within $5 \mathrm{~km}$ radius, but not those within $1 \mathrm{~km}$ radius from the plot (Table 4.3; Fig. 4.7a, b). 

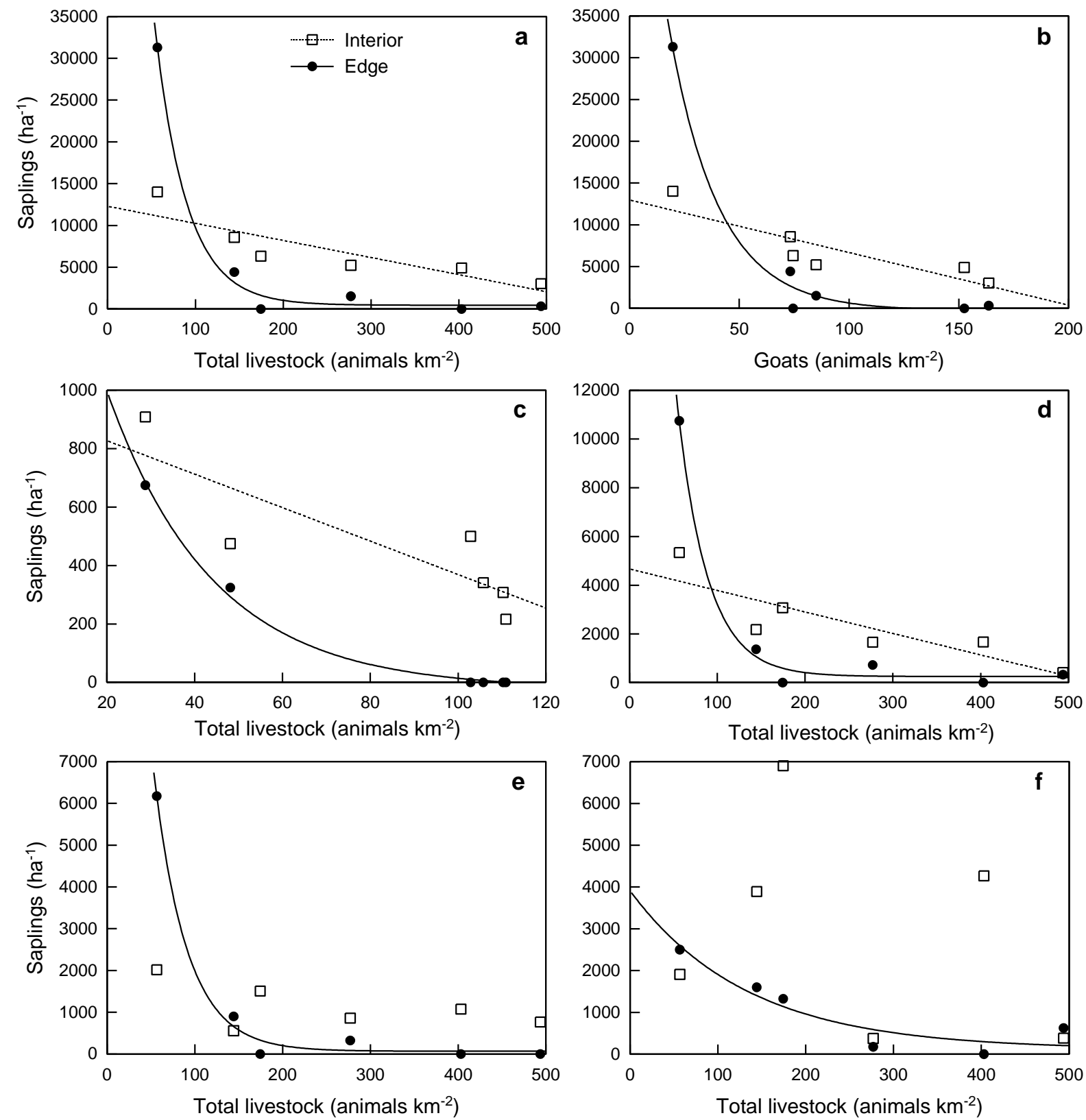

Fig. 4.7. Densities of sapling-sized trees in the forest interior and at the forest edge as a function of livestock density: (a) total of live saplings and total livestock within $1 \mathrm{~km}$ radius, (b) total of live saplings and goats within $1 \mathrm{~km}$ radius, (c) undamaged saplings (0\% defoliation) and total livestock within $5 \mathrm{~km}$ radius, (d) saplings with $26-50 \%$ defoliation and total livestock within $1 \mathrm{~km}$ radius, (e) saplings with 76-99\% defoliation and total livestock within $1 \mathrm{~km}$ radius, (f) dead saplings and total livestock within $1 \mathrm{~km}$ radius. Linear regression for forest-interior data and non-linear regression (exponential decline) for forest-edge data; for $r$ and $P$ values see Table 3 
Table 4.3. Correlation between livestock densities within 1 or $5 \mathrm{~km}$ radius from the studied $L$. sibirica stands (forest interior and edge) and the density of saplings (in trees $\mathrm{ha}^{-1}$ ) in browsing damage classes.

\begin{tabular}{|c|c|c|c|c|c|}
\hline \multirow[t]{2}{*}{ Damage class $^{\mathrm{a}}$} & \multirow[t]{2}{*}{$\mathrm{L}^{\mathrm{b}}$} & \multicolumn{2}{|c|}{ Livestock within $1 \mathrm{~km}^{\mathrm{c}}$} & \multicolumn{2}{|c|}{ Livestock within $5 \mathrm{~km}$} \\
\hline & & Interior & Edge & Interior & Edge \\
\hline \multirow[t]{2}{*}{$0 \%$} & $\mathrm{~T}$ & - & - & $-0.85(0.02)$ & $1.00(<0.001)$ \\
\hline & $\mathrm{G}$ & - & - & $-0.86(0.02)$ & $1.00(<0.001)$ \\
\hline \multirow[t]{2}{*}{$1-25 \%$} & $\mathrm{~T}$ & $-0.72(0.05)$ & $1.00(<0.001)$ & $-0.98(<0.001)$ & - \\
\hline & $\mathrm{G}$ & $-0.66(0.08)$ & $1.00(<0.001)$ & $-0.98(<0.001)$ & - \\
\hline \multirow[t]{2}{*}{$26-50 \%$} & $\mathrm{~T}$ & $-0.87(0.01)$ & $1.00(<0.001)$ & - & - \\
\hline & $\mathrm{G}$ & $-0.88(0.01)$ & $0.99(<0.001)$ & - & - \\
\hline \multirow[t]{2}{*}{$51-75 \%$} & $\mathrm{~T}$ & - & $1.00(<0.001)$ & - & - \\
\hline & $\mathrm{G}$ & - & $1.00(<0.001)$ & - & - \\
\hline \multirow[t]{2}{*}{$76-99 \%$} & $\mathrm{~T}$ & - & $1.00(<0.001)$ & - & - \\
\hline & $\mathrm{G}$ & - & $0.99(<0.001)$ & - & - \\
\hline \multirow[t]{2}{*}{ Sum live saplings } & $\mathrm{T}$ & $-0.87(0.01)$ & $1.00(<0.001)$ & $-0.75(0.05)$ & - \\
\hline & $\mathrm{G}$ & $-0.88(0.01)$ & $0.99(<0.001)$ & $-0.73(0.05)$ & - \\
\hline \multirow[t]{2}{*}{ Dead saplings } & $\mathrm{T}$ & - & $0.94(0.02)$ & - & - \\
\hline & $\mathrm{G}$ & - & $0.87(0.05)$ & - & - \\
\hline
\end{tabular}

a Percentage of defoliation by browsing

${ }^{\mathrm{b}}$ Livestock density (in animals $\mathrm{km}^{-2}$ ) included in the regression models: $\mathrm{T}$, total livestock (goats, sheep, yaks, horses, camels); G, goats

${ }^{\mathrm{c}}$ Pearson correlation coefficients from linear regression for the forest interior and correlation coefficients from nonlinear regression with model for exponential decline $\left[\mathrm{y}=a+\mathrm{e}^{(-c(\mathrm{x}-b))}\right]$ for forest-edge data; $P$ values in brackets. Data for $P>0.10$ are not shown

\subsubsection{Recent seedling emergence and correlations with livestock density}

In 2010, 46 \pm 17 1-yr old seedlings per $\mathrm{m}^{2}$ of $L$. sibirica were found in the forest interior and $64 \pm 19$ 1 -yr old seedlings per $\mathrm{m}^{2}$ were found at the forest edge $(P=0.11, U$-test). In $2011,9 \%$ of these individuals $\left(5.5 \pm 1.3\right.$ seedlings $\left.\mathrm{m}^{-2}\right)$ in the interior and $12 \%$ of the individuals $(5.3 \pm 2.6$ seedlings $\mathrm{m}^{-2}$ ) at the edge were recovered as 2-yr old seedlings, when the same subplots were revisited. In contrast to the sapling-sized trees, the density of the 1 and 2-yr old seedlings increased with livestock density following a linear relationship (Fig. 4.8). The correlation coefficients for total livestock density within $1 \mathrm{~km}$ radius from the sample plot (Fig. 4.8) were close to those for the density of goats ( $1 \mathrm{yr}: r=0.78, P=0.03 ; 2 \mathrm{yr}: r=0.88, P=0.01$ ). No relationship was found between seedling density and livestock density within a radius of $5 \mathrm{~km}$. 

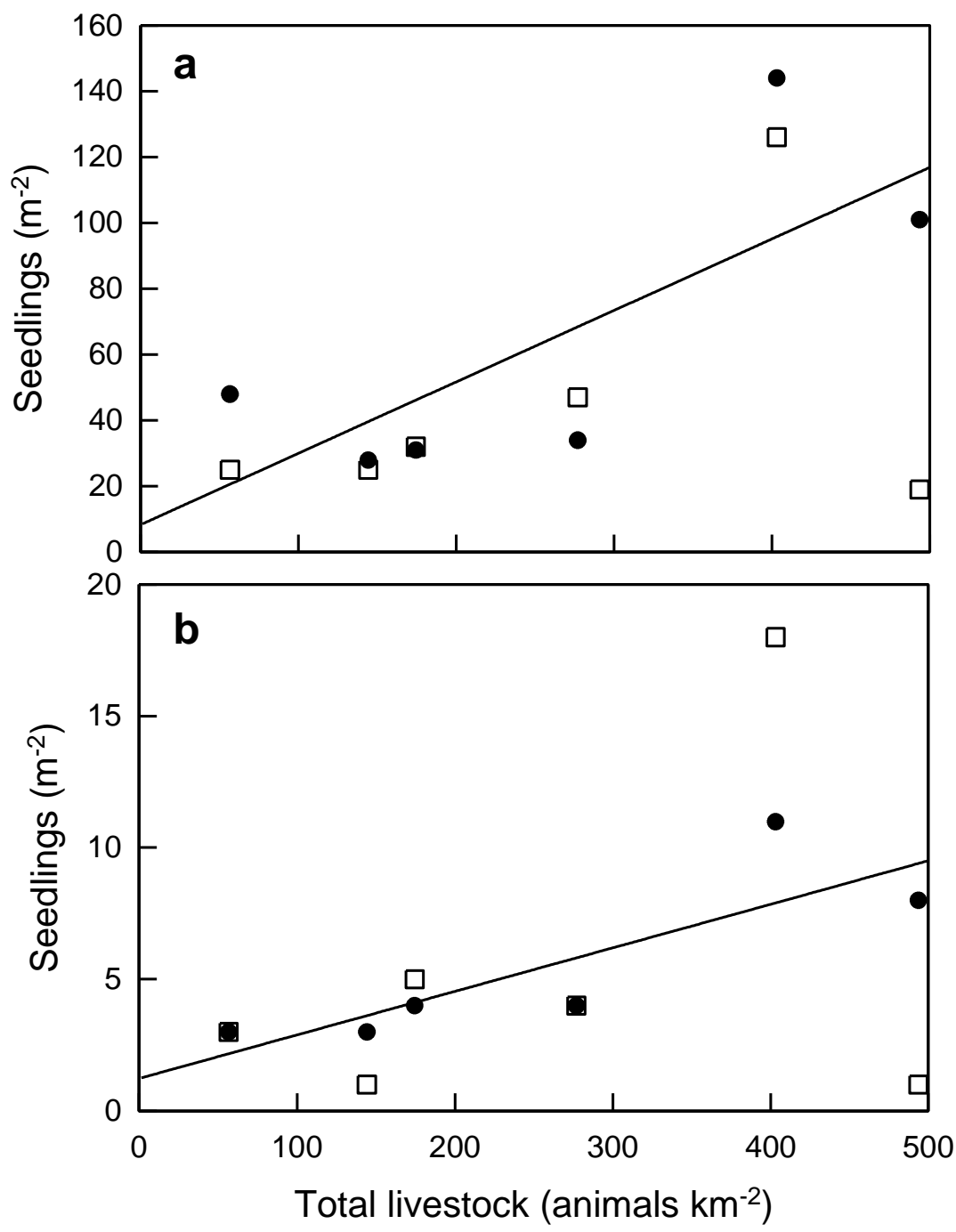

Fig. 4.8. Densities of (a) 1-yr old and (b) 2-yr old L. sibirica seedlings in the forest interior and at the forest edge as a function of total livestock density within $1 \mathrm{~km}$ radius. In contrast to the interior, significant linear correlations occur at the edge: (a) $r=0.76, P=0.04$, (b) $r=0.84, P=0.02$

\subsubsection{Soil seed bank}

A total of 3464 seeds were counted in the $1 \mathrm{~m} \times 1 \mathrm{~m}$ subplots. Forty percent of them were classified as not viable in the field, because they had empty seed capsules. Two percent of the seeds had germinated, but seedling emergence had been unsuccessful. The remaining $58 \%$ of the seedlings looked intact and were taken to the growth chamber. The densities of viable looking seeds in the field were $182 \pm 43$ seeds $\mathrm{m}^{-2}$ in the forest interior and $154 \pm 51$ seeds $\mathrm{m}^{-2}$ at the forest 
edge. At good climatic condition for L. sibirica germination, only $14 \%$ of these seeds germinated. Cutting the seeds which had not germinated in the growth chamber showed that these seeds, albeit looking intact from outside, were empty and dry inside. Based on the germination success in the laboratory, the density of viable seeds in the field is roughly estimated to be 26 seed $\mathrm{m}^{-2}$ in the interior and 22 seeds $\mathrm{m}^{-2}$ at the edge.

\subsection{Discussion}

Rich regeneration of $L$. sibirica until present in the interior and the presence of viable seeds in soils in the interior and the edges of the forests of the Mongolian Altai show that tree establishment is not limited by recent changes in climate. Together with the finding that tree-ring width has increased with increasing temperatures in the high elevation forests of the Mongolian Altai (D'Arrigo et al., 2000; Dulamsuren et al., 2013a), this result attests the forests of this region a promising perspective in terms of the climatic growth conditions. Thereby, the forests of the Mongolian Altai differ from many other, but not all, L. sibirica forests at the southern fringe of the Eurosiberian boreal forest, where rising temperatures have deteriorated tree water relations and have reduced rejuvenation (Dulamsuren et al., 2010, 2013b).

The favorable climatic conditions for the regeneration of L. sibirica in the Mongolian Altai are counteracted by the high local livestock densities around the small forest patches of this area. Exponential decline of sapling density with increasing livestock density at the forest edges and linear decline in the forest interiors shows that the livestock, which mainly grazes the steppe and the forest edges, but also regularly penetrates inside the forests (Hauck and Lkhagvadorj, 2013; Lkhagvadorj et al., 2013a), has a strong potential to inhibit forest regeneration. The failure of tree establishment at the forest edge after the 1970s is an indicator of apparently increased local livestock densities. The small variation of damage severity across sapling height classes suggests that saplings do not fully recover from damage through livestock browsing with age. This conclusion agrees with the results of our wood-anatomical studies, where decades-old open injuries were found in the tree stems. Stem injuries and defoliation, which result in reduced wood production and the frequent occurrence of narrow rings, are likely to be a key factor that has prevented many small tree individuals for decades from growing out of sapling size (Brander et al., 
1990). However, livestock is certainly only one cause for the suppressed growth of many individuals of L. sibirica. Suppression and finally the death of trees as the consequence of an unfavorable carbon balance is also the natural consequence of competition for light, water and other resources in forests without systematic silvicultural thinning (Kubota and Hara, 1996; Wright et al., 2000; Duchesneau et al., 2001). Intraspecific competition clearly played a role in the forest interior, where the density of highly damaged and dead sapling-sized trees was decoupled from livestock density. By contrast, there were close negative correlations between livestock density and sapling densities of all damage classes at the forest edge, where the competition between trees for light and water is less and livestock densities are higher. The decrease even of the density of dead sapling-sized trees with increasing livestock density reflects the strong control of livestock density on the density of live sapling-sized trees.

Remarkably, seedling density responds to livestock density in right the opposite way than sapling density does. The increase of seedling density with increasing livestock density at the forest edge suggests that tree establishment is inhibited here in the seedling stage by competition from the ground vegetation (Castro et al., 2002). This conclusion agrees with the fact that the promoting effect of fire on the regeneration of $L$. sibirica and L. gmelinii forests in Siberia is primarily due to the creation of free space for the seedlings as the consequence of the combustion of parts of the ground vegetation and organic matter (Matveev and Usoltzev, 1996). The beneficial effect of livestock grazing on seedlings at the forest edges of the Mongolian Altai suggests that $L$. sibirica in the seedling state is apparently not a preferred diet of the livestock, as otherwise the promotional effect of grazing should be neutralized by the consumption of seedlings by the livestock.

The very similar correlations of seedling and sapling densities, on the one hand, with total livestock and goat densities, on the other hand, suggest that goats are mainly responsible for the livestock effect on forest regeneration. This is consistent with both our field observations and the known aptitude of goats to consume woody plants (Sankey et al., 2006). The dominant influence of goats even on seedling density can be explained with the fact that their interest in woody plants drives them more often than other species of livestock to the forest edge (Lkhagvadorj et al., 2013a) and that the seedlings might also benefit from the removal of larch sapling-sized trees. Unfortunately, goats are economically more important than all other species of livestock in the Mongolian forest-steppe, because they produce cashmere which is much in demand on the world 
market (Lecraw et al., 2005). In our study area in the Mongolian Altai, the pastoralists earn $70 \%$ of their cash income from livestock husbandry from the sale of cashmere (Lkhagvadorj et al., 2013a). Owing to its economic importance, the number of goats in Mongolia has tripled between 1990 and 2011 (Lkhagvadorj et al., 2013b). This increase in goats explains the strong increase in the frequency of wedging rings (resulting from injuries of the stem) and reaction wood (resulting from tree deformations due to trampling and feeding) in the sapling-sized trees after 1990. Wild herbivores, like deer, have become very rare in the forest-steppe of the Mongolian Altai and are unlikely to play a significant role in the damage observed in the young larch trees.

\subsection{Conclusions}

Climate is presently not the key factor limiting the regeneration of L. sibirica forests in the Mongolian Altai. Rather, livestock browsing, especially of goats, owned by local pastoralists, reduces forest regeneration. This influence is stronger at the forest edges, where since the late 1970s no larch individuals have established and grown beyond seedling size. The apparent promotion of larch seedlings by livestock through the reduction of competition by the vegetation suggests that seedling survival and perhaps also emergence is decisively reduced by competition at the forest edges to the grasslands. However, since the promotion of seedlings is followed by feeding damage in the sapling stage, this beneficial effect of livestock grazing in the earliest stage of tree establishment is more of scientific than practical interest. High livestock densities, reduced mobility of the local pastoralists (Lkhagvadorj et al., 2013a) and sharply increased logging activities during the past 20 years (Dulamsuren et al., 2013a) raise concern on the future of the forests in the Mongolian Altai, which have established in this region c. 10700 years ago (Rudaya et al., 2008).

\section{Acknowledgments}

The study was supported by a grant of the Volkswagen Foundation to M.H, C.D. and C.L. for the project 'Forest regeneration and biodiversity at the forest-steppe border of the Altai and Khangai Mountains under contrasting developments of livestock numbers in Kazakhstan and Mongolia' and 
by a scholarship of the German Academic Exchange Service (Deutscher Akademischer Austauschdienst, DAAD) to M.K. We are thankful to the Altai Tavan Bogd National Park (Ulgii) for permissions for field work. We are grateful to B. Jadambaa, Yo. Yoroolt, B. Bat-Enerel, Kh. Ganbaatar, and D. Saindondov (Ulan Bator) for their assistance in the field. 


\section{References}

Brandner, T.A., Peterson, T.O., Risenhoover, K.L., 1990. Balsam fir on Isle Royale: effects of moose herbivory and population density. Ecology 71, 155-164

Buttoud, G., Yunusova, I., 2002. A 'mixed model' for the formulation of a multipurpose mountain forest policy. Theory vs. practice on the example of Kyrgyzstan. For Pol Econ 4, 149-160

Buffum, B., Gratzer, G., Tenzin, Y., 2009. Forest grazing and natural regeneration in a late successional broadleaved community forest in Bhutan. Mountain Research and Development 29, 30-35

Castro, J., Zamora, R., Hódar, J.A., 2002. Mechanisms blocking Pinus sylvestris colonization of Mediterranean mountain meadows. J Veg Sci 13, 725-731

D’Arrigo, R., Jacoby, G., Pederson, N., Frank, D., Buckley, B., Baatarbileg, N., Mijiddorj, R., Dugarjav, Ch., 2000 Mongolian tree-rings, temperature sensitivity and reconstructions of northern hemisphere temperature. Holocene 10, 669-672

Duchesneau, R., Lesage, I., Messier, C., Morin, H., 2001. Effects of light and intraspecific competition on growth and crown morphology of two size classes of understory balsam fir saplings. For Ecol Manage 140, 215-225

Dulamsuren, Ch., Hauck, M., Leuschner, C., 2010. Recent drought stress leads to growth reductions in Larix sibirica in the western Khentey, Mongolia. Glob Change Biol 16, 30243035

Dulamsuren, Ch., Khishigjargal, M., Leuschner, C., Hauck, M., 2013a. Response of tree-ring width to climate warming and selective logging in larch forests of the Mongolian Altai. J Plant Ecol, doi, 10.1093/jpe/rtt019

Dulamsuren, Ch., Wommelsdorf, T., Zhao, F., Xue, Y., Zhumadilov, B.Z., Leuschner, C., Hauck, M., 2013b. Increased summer temperatures reduce the growth and regeneration of Larix sibirica in southern boreal forests of eastern Kazakhstan. Ecosystems, in press.

Eckstein, D., Bauch, J., 1969. Beitrag zur Rationalisierung eines dendrochronologischen Verfahrens und zur Analyse seiner Aussagesicherheit. Forstwiss Centralbl 88, 230-250

Evans, H.J., Nason, A., 1953. Pyridine nucleotide-nitrate reductase from extracts of higher plants. Plant Physiol 28, 233-254 
Fernández-Giménez, M., Batjav, B., Baival, B., 2012. Lessons from the dzud: adaptation and resilience in Mongolian pastoral socio-ecological systems. World Bank, Washington DC.

Fujita, N., Amartuvshin, N., Ariunbold, E., 2013. Annual production and species diversity of Mongolian pasture plants in relation to grazing pressure by livestock. In: Yamamura, N., Fujita, N., Maekawa, A., (eds) The Mongolian Ecosystem Network: environmental issues under climate and social changes. Springer, Tokyo, pp 131-143

Hauck, M., Lkhagvadorj, D., 2013. Epiphytic lichens as indicators of grazing pressure in the Mongolian forest-steppe. Ecol Indic 32, 82-88

Hughes, J.D., Thirgood, J.V., 1982. Deforestation, erosion, and forest management in ancient Greece and Rome. J For Hist 26, 60-75

Ishii, R., Fujita, N., 2013. A possible future picture of Mongolian forest-steppe vegetation under climate change and increasing livestock: results from a new vegetation transition model at the topographic scale. In: Yamamura, N., Fujita, N., Maekawa, A., (eds) The Mongolian Ecosystem Network: environmental issues under climate and social changes. Springer, Tokyo, pp 65-82

Janzen, J., 2005. Mobile livestock-keeping in Mongolia: present problems, spatial organization, interactions between mobile and sedentary population groups and perspectives for pastoral development. Senri Ethnol Stud 69, 69-97

Keyser, A.R., Kimball, J.S., Nemani, R.R., Running, S.W., 2000. Simulating the effects of climate change on the carbon balance of North American high-latitude forests. Glob Change Biol 6 (Suppl 1), 185-195

Körner, C., Sarris, D., Christodoukalis, D., 2005. Long-term increase in climatic dryness in the East-Mediterranean evidenced for the island of Samos. Reg Environ Change 5, 27-36

Kubota, Y., Hara, T., 1996. Allometry and competition between saplings of Picea jezoensis and Abies sachalinensis in a sub-boreal coniferous forest, northern Japan. Ann Bot 77, 529-538

Lecraw, D.J., Eddleston, P., McMahon, A., 2005. A value chain analysis of the Mongolian cashmere industry. USAID Economic Policy Reform Competitiveness Project, Ulan Bator

Lkhagvadorj, D., Hauck, M., Dulamsuren, Ch., Tsogtbaatar, J., 2013a. Pastoral nomadism in the forest-steppe of the Mongolian Altai under a changing economy and a warming climate. $\mathbf{J}$ Arid Environ 88, 83-89 
Lkhagvadorj, D., Hauck, M., Dulamsuren, Ch., Tsogtbaatar, J., 2013b. Twenty years after decollectivization: mobile livestock husbandry and its ecological impact in the Mongolian forest-steppe. Human Ecol, in press

Luyssaert, S., Schulze, E.D., Börner, A., Knohl, A., Hessenmöller, D., Law, B.E., Ciais, P., Grace, J., 2008. Old-growth forests as global carbon sinks. Nature 455, 213-215

Matveev, P.M., Usoltzev, V.A., 1996. Post-fire mortality and regeneration of Larxi sibirica and Larix dahurica in conditions of long-term permafrost. In: Goldammer, J.G., Furyaev, V.V., (eds) Fire in ecosystems of boreal Eurasia. Kluwer, Dordrecht, pp 366-371

Östlund, L., Zackrisson, O., Axelsson, A.L., 1997. The history and transformation of a Scandinavian boreal forest landscape since the $19^{\text {th }}$ century. Can J For Res $27,1198-1206$

Rudaya, N.A., Tarasov, P.E., Dorofuyek, N.I., Kalugin, I.A., Andreev, A.A., Diekmann, B., Daryin, A.V., 2008. Environmental changes in the Mongolian Altai during the Holocene. Archaeol Ethnol Anthropol Eurasia 36, 2-14

Sankey, T.T., Montagne, C., Graumlich, L., Lawrence, R., Nielsen, J., 2006. Lower forestgrassland ecotones and 20th century livestock herbivory effects in northern Mongolia. For Ecol Manage 233, 36-44

Schweingruber, F.H., Börner, A., Schulze, E.D., 2006. Atlas of woody plant stems: evolution, structure, and environmental modifications. Springer, Berlin

Sharkhuu, N., Sharkhuu, A., 2012 Effects of climate warming and vegetation cover on permafrost of Mongolia In: Werger MJA, van Staalduinen MA (eds) Ecological problems and livelihoods in a changing world, Springer, Dordrecht, pp 445-472

Tsogtbaatar, J., 2004. Deforestation and reforestation needs in Mongolia. For Ecol Manage 201, 57-63

Wright, E.F., Coates, K.D., Canham, C.D., 2000. Effects of suppression and release on sapling growth for 11 tree species of northern, interior British Columbia. Can J For Res 30, 15711580 


\section{CHAPTER}

5

\section{SYNTHESIS}




\section{Synthesis}

The previous chapters described the tree growth responses to climate change and stand structure including regeneration under numerous land use activity of Siberian larch (Larix sibirica L.) in forest- steppe ecotone of northern Mongolia. While, the forest-steppe landscapes are generally not only formed by the semiarid, strongly continental climate, but are also the result of the longlasting pastoral land use, which affects both grasslands and

Climate of the research sites are characterized by an increased annual mean temperature of $1.9^{\circ} \mathrm{C}$ at constant annual precipitation in Mt. Bogd Uul since, 1965 (chapter 2), and the same climate trend substantiated an increase of temperature by $2.1^{\circ} \mathrm{C}$ at constant precipitation in Altai Mountains (chapter 3 and 4). Thus, increase in aridity in both areas occurred, and it agrees with observed strong drying trend in northern hemisphere, since mid-1950, affecting Mongolia (Dai et al., 2004; Batima et al., 2005).

Field research was conducted in high altitude (2300 m a.s.1.) Altai Mountains, that is subject to intensive land use activity, particularly selective logging and livestock grazing in forested area. By contrast another research area Mt.Bogd Uul (1800 m a.s.1.), is one of the oldest protected area from direct human activity, and is well preserved.

The following chapter sections integrate the information from our studies and put to wider context of climate change and numerous land use influences for forest management in local and regional level as well as forest-steppe ecology research in Mongolia.

\subsection{Climate responses of tree-ring width and wood anomalies in larch forest}

Numerous studies have investigated effects of climate factors on tree-ring width from larch forest growing in forest-steppe ecotone of northern Mongolia (Dulamsuren et al., 2010a.b, 2011; De Grandpré et al., 2011). However, assumptions regarding the consistency of tree-temperature sensitivities have been challenged by findings that detail diverging signals and climate trends within regions (D’Arrigo et al., 2008; Dulamsuren et al., 2010a) and indirect relationships. 
Given this background, we investigated climate responses of increasingly isolated mosaic larch forest in Altai Mountains, which was not systematically studied before and Mt. Bogd Uul, which is the southernmost forest in the Khentei province.

In Altai Mountains, climate-response analysis revealed that radial stem increment was promoted by the temperature in early summer, but also high precipitation in spring and in the year before tree-ring formation. Therefore, trees benefit from the increased temperatures. While Altai Mountains are a cold, high-elevation environment with a subzero annual mean temperature, the increase in temperature has promoted the growth of the Siberian larch trees.

Our study from Mt. Bogd Uul shows that increased summer drought is the key factor which has already reduced radial stem growth of $L$. sibirica in the past decades. While, tree-ring width increased with increasing summer precipitation during current and previous year. This findings support the observed growth reductions dependent on the recent drought stress in Mongolia (Jacoby et al., 1999; Dulamsuren et al., 2010b.c; De Grandpré et al., 2011).

The most significant change in wood anatomy was the decline of wide latewood, which is attributable to the increase of summer days with a mean temperature $>15{ }^{\circ} \mathrm{C}$ and drought periods. Increasing summer drought is also thought to have caused the repeated occurrence of missing rings since the $1960 \mathrm{~s}$, which were not observed in the late $19^{\text {th }}$ and early $20^{\text {th }}$ century. The threat of climate change poses the risk that many stands and landscapes may become unhealthy because they are no longer adapted to the climate and the associated disturbance regimes (Kimmins, 2004).

\subsection{Influences of logging and livestock grazing on larch forest regeneration}

The Mongolian Altai is not only experiencing an increase of annual mean temperature but is also under the influence of long-lasting pastoral land use, which affects both grasslands and forests. During recent decades, research area has been subjected to intensive livestock grazing and selective logging by local nomadic herders (Lhagvadorj et al., 2013).

A tree-ring series-based reconstruction of logging intensity since 1935 suggests that moderate selective logging occurred throughout the study period. However, selective logging was strongly intensified after 1990. Tree stump densities showed that the ratio of felled to live trees was $2: 1$ in the interior or even $0.9: 1$ at the edges of the forests and most logging occurred 
during the past 20 years. A close correlation of the ratio of felled to live trees with the density of summer camps of pastoral nomads in the vicinity suggests that trees are primarily felled by the local people.

Forest regeneration occurred throughout the $20^{\text {th }}$ and the early $21^{\text {st }}$ centuries in the forest interiors, but ceased after the late 1970s at forest edges. Remarkably, most of larch saplings had visible damage from livestock browsing and their density decreased with livestock density following a linear slope in the interior and an exponential decline at the edge. In addition, beneficial effect of livestock grazing on seedlings along the forest edge were described, however it surely was not result of a direct effect of grazing, instead was result of inhibited competition from vegetation as well as seedlings state which is apparently not a preferred diet of the livestock.

Near-consistency of the correlations of total livestock and goat densities with sapling and seedling densities suggests that the control of larch regeneration is mostly exerted by goats, which is main income source from livestock husbandry to local herders. It accompanied those high livestock densities, reduced mobility of the local pastoralists after 1990 in Altai Mountains. These findings support the results of an abrupt decline of larch forest establishment, which coincide with locally increased grazing pressure during the $20^{\text {th }}$ century in northern Mongolia (Sankey et al., 2006). Additionally, the present practice of unplanned selective logging by the local population of pastoral nomads will lead to a decline of forest area in the Mongolian Altai in the near future (Lkhagvadorj et al., 2013).

One thing about the present warming, that differs from conditions during the repeated abandonment and reoccupation of Canada, northern US, and northern Eurasia is that human land use covers much of the surface needed for plant migration and establishment. Even, if today's conifers are capable of establishing new populations by northward dispersal of propagules generation after generation, there may be few available places for the seeds to germinate (Eckenwalder, 2009). 


\subsection{Concluding remarks.}

The present work gave detailed regional information on climate and land use responses presumably drought-affected Siberian larch (Larix sibirica L.) forests in forest steppe ecotone in Mongolia. The analysis of the present situation of the forests in Mongolia is a precondition for the discussion of potential future responses to a warming climate including intensive forest utililization.

The results revealed strong negative consequences for the forest-steppe ecotone in the Mt. Bogd Uul due to increasing aridity. By contrast, in the Altai Mountain the increasing temperature has promoted the growth of the Siberian larch trees, but stand dynamics is increasingly affected and regeneration hampered due to unplanned intensive forest utilization.

A retreat of the forest borderline in the future is very likely. As per Mongolia, the reduction of the forested area would have strong negative impact on biodiversity and options for land use, as the country has already subjected to limited forest resources. Moreover, it will have far reaching socio-economic consequences as the country is forested very sparse and locals strongly depend on the forests as natural resources.

Further investigations should include the experimental research, using enclosure from intensive grazing pressure on forest natural regeneration, including seed germination, seedling survival rate, and saplings annual growth and survival rate in larch forest. A comparison of the conditions at enclosure and open area would provide additional information on the present situation of grazing pressure, like everywhere in Mongolia, and the probable future development of larch forest. In addition, investigations partly focusing on larch forest annual seed production frequency (seed rain years) and seed germination condition may be included for further research. 


\section{Reference}

D’Arrigo, R., Wilson, R., Liepert, B., Cherubini, P., 2008. On the divergence problem' in northern forests: a review of the tree-ring evidence and possible causes. Global Planet Change 60 (3-4), 289-305.

Batima, P., Natsagdorj, L., Gombluudev, P., Erdenetsetseg, B., 2005. Observed climate change in Mongolia. Assessments of Impacts and Adaptations of Climate Change. Workings papers 12, 1-26.

Dai, A., Trenberth, K.E., Qian, T., 2004: A global data set of Palmer Drought Severity Index for 1870-2002: Relationship with soil moisture and effects of surface warming. Journal of Hydrometeoroly 5, 1117-1130.

Dulamsuren, Ch., Hauck, M., Khishigjargal, M., Leushner H.H., Leuschner, C., 2010a. Diverging climate trends in Mongolian taiga forests influence growth and regeneration of Larix sibirica. Oecologia 163, 1091-1102.

Dulamsuren, Ch., Hauck M., Leuschner, C., 2010b. Recent drought stress leads to growth reductions in Larix sibirica in the western Khentey, Mongolia. Global Change Biology 16, 3024-3035.

Dulamsuren, Ch., Hauck, M., Leuschner, H.H., Leuschner C., 2010c. Gypsy moth-induced growth decline of Larix sibirica in a forest-steppe ecotone. Dendrochronologia 28, 207213.

Dulamsuren, Ch., Hauck, M., Leuschner, H.H., Leuschner, C., 2011. Climate response of treering width in Larix sibirica growing in the drought-stressed forest-steppe ecotone of northern Mongolia. Annals of Forest Science 68, 275-282.

Eckenwalder, J.E., 2009. Conifers of the world. The complete reference. Timber Press. Portland. London.

De Grandpré, L., Tardif, J.C., Hessl, A., Pederson, N., Conciatori, F., Green, T.R., Oyunsanaa, B., Baatarbileg, N., 2011. Seasonal shift in the climate responses of Pinus sibirica, Pinus sylvestris, and Larix sibirica trees from semi-arid, north central Mongolia. Canadian Journal of Forest Research 4, 11242-1255.

Jacoby, G., D'Arrigo, R., Pederson, N., Buckley, B., Dugarjav, C., Mijiddorj, R., 1999. Temperature and precipitation in Mongolia based on dendroclimatic investigations. IAWA . Journal. 20, 339-350. 
Kimmins, J.P., 2004. Forest ecology: a foundation for sustainable forest management and environmental ethics in forestry: Third Edition, ISBN0-13-066258-5.

Lkhagvadorj D., Hauck, M., Dulamsuren, Ch., Tsogtbaatar, J., 2013. Pastoral nomadism in the forest-steppe of the Mongolian Altai under a changing economy and warming climate. Arid Environments. 88, 83-89.

Sankey T.T., Montagne, C., Graumlich, L., Lawrence, R., Nielsen, J., 2006. Lower forest grassland ecotones and $20^{\text {th }}$ century livestock herbivory effects in northern Mongolia. Forest Ecology and Management 23, 36-44. 


\section{Acknowledgements}

I am grateful to many people who contributed to the production of this thesis.

First of all, I am very grateful from bottom of my heart to Dr. Choimaa Dulamsuren, who made my heart and mind attracted to the tree ring studies, moreover her extensive supervision throughout all of time in my study and invaluable supports to me not only in research, also to my family to live here in Goettingen. I would never go so far like this without their endorsement and supervision.

I would like to express my gratitude overwhelmingly to my supervisors, Prof. Markus Hauck, Prof. Christoph Leuschner, and Dr Dulamsuren Choimaa for giving me encourage to do this study and approved papers and thesis.

I owe my gratitude to Dr Clyde Goulden from Drexel University, USA, for his encouragement for me to built fundamental knowledge and research experience in forest ecology. I also extend my sincere thanks to Prof. Erwin Bergmeier, Prof. Hermann Behling, Prof. Stefan Scheu and Prof. Holger Kreft for their acceptance to be the committee members.

My sincere thank to go Dr Hanns Hubert Leuschner, who guided me through wood anatomy and tree-ring world and his supports.

I gratefully acknowledge the support of German Academic Exchange Service (DAAD) for my stay in Germany and this research would not have been possible without this support. Their support is not only finance but also providing a chance to new culture and knowledge exchange.

I am very grateful to my excellent research assistant B. Jadambaa, including Yo. Yoroolt, B. BatEnerel, Kh. Ganbaatar and D. Saindondov (Ulan Bator) as well as other field team members for their assistance in the field research.

I also want to thank everybody from the Plant Ecology working group in the Weende Experimental Botanical Garden. Wholehearted thanks to Dr. Frederica Beyer, Dr. Byambajav Buyandelger, Delgerjargal Dugarjav and Chenlemuge, for their friendship and supporting me whenever.

I am grateful to all my Mongolian friends in Goettingen, who have been spending many times together and helping each other.

Most importantly, I want thank to my family, in particular my mother Batsuuri Dulamsuren and father Tuntger Mookhor, for their encouragement and believing in my skills. Finally, I want to express the love and appreciation especially to my husband Badamsambuu Batdemberel, who never let me down from the very beginning and standing by me to complete this program including his invaluable encouragement and our eldest son Chingun for his being good pupil and big brother of twins. Very end, I give my especial thank to our twin babies Bilguun and Irmuun for giving us new pages with full energy and fortune in my life. 


\section{CURRICULUM VITAE}

Personal Information:

$\begin{array}{ll}\text { Name: } & \text { Khishigjargal Mookhor } \\ \text { Birth date: } & \text { June 17, 1977 } \\ \text { Birth place: } & \text { Bayan-Ondor/Bayankhongor province, Mongolia } \\ \text { Nationality: } & \text { Mongolian } \\ \text { Family status: } & \text { Married, with 3 children }\end{array}$

Education:

2009-2013

PhD Study in the program "Biodiversity and Ecology" at GeorgAugust-University of Göttingen, Germany

2000-2002

Master of Science in Forestry, National University Mongolia, Ulan Bator

1995-1999

Bachelor of Science in Forestry, National University Mongolia, Ulan Bator

1985-1995

Secondary School, Bayankhongor province, Mongolia

Work experience:

2007-2009

Forest Ecology Assistant Lecturer, School of Ecology and Technological Development, Mongolian State Agriculture University, Ulan Bator, Mongolia

2002-2006

Forest Ecologist, Project "Dynamics of Biodiversity Loss and Permafrost Melt in Lake Hővsgől National Park" Hővsgől GEF Project, Institute of Geoecology, Mongolian Academy of Sciences

1999-2002

Forest Researcher, Institute of Geo-Ecology, Mongolian Academy of Sciences, Ulan Bator

\section{Workshops and conferences:}

Biodiversity Research in Mongolia (International symposium) Halle (Saale), Germany. 

Lisbon, Portugal.

2010

2010

2008

2006

2005-2006

2001
Dendrochronological Field Week of WorldDendro 2010. Stockholm University.

WorldDendro 2010 (International Conference). Lapland University, Finland.

The Long History of Wood Utilization (International Conference EuroDendro-2008) Hallstatt, Austria.

Changes in Climate, Ecology and Patterns of Pastoral Nomadism in Lake Hővsgől National Park, (International Conference), Mongolia.

Ecosystem Modeling Workshop (International workshop), Mongolia.

First Mongolian Dendrochronological Field Week (Training course), Mongolia.

\section{Research stays abroad:}

2008

2005

Short-term Research Scholarship at the Department of Ecology and Ecosystem Research, Albrecht-von-Haller Institute of Plant Sciences, Georg August University of Göttingen, Germany, 6 months

Internship position in forest ecology at the Flambeau Experiment, northern Wisconsin, Forest Landscape Ecology Laboratory, University of Wisconsin, Madison, Wisconsin, USA, 3 months

\section{Publications:}

Dulamsuren, Ch., Khishigjargal, M., Leuschner, C., Hauck, M. 2013. Response of tree-ring width to climate warming and selective logging in larch forests of the Mongolian Altai. Journal of Plant Ecology. Doi:10.1093/jpe/rtt019, pp 1-15.

Dulamsuren, Ch., Hauck, M., Khishigjargal, M., Leuschner, H.H., Leuschner, C. 2010. Diverging climate trends in Mongolian taiga forests influence growth and regeneration of Larix sibirica. Oecologia 163: 1091-1102.

Khishigjargal, M., Dugarjav, Ch. 2006. Forest regeneration in the Hovsgol region. Abstracts of the Conference Changes in Climate, Ecology and Patterns of Pastoral Nomadism in Lake Hovsgol National Park, Mongolia. pp. 33-34 (in Mongolian). 
Khishigjargal, M., Enkhzaya, D. 2006. Some research results on the effects of small rodents on larch seed germination in nature. Climate Change and Mongolian Forest Workshop. E-book. UlanBator (in Mongolian).

Otgonsuren, A., Avaadorj, M., Khishigjargal, M., Goulden, C.E. 2006. Soil $\mathrm{CO}_{2}$ flux of Hovsgol larch forest ecosystem. Mongolian Geoscientist 29: 104-111.

Baigal-Amar, T., Khishigjargal, M. 2004. Effects of gypsy moth (Lymantria dispar L.) on larch saplings. Scientific Journal Series of the National University of Mongolia dedicated to Problems on Mongolian Forests 14/225: 86-91(in Mongolian).

Khishigjargal, M. 2004. Convenient conditions for seed germination in larch taiga forests. Scientific Journal Series of national University of Mongolia dedicated to Problems on Mongolian Forests 14/225:16-23 (in Mongolian).

Khishigjargal, M., Oyunsanaa, B. 2003. Some results of the study of larch forest regeneration at the eastern shore of Lake Hovsgol. Scientific Transactions of Technical University 1/52: 226-230 (in Mongolian).

Oyunsanaa, B., Khishigjargal, M. 2003. Age structure and historical fire dynamics of larch forests at Lake Hovsgol. Abstract of the International Conference on Western Mongolia and their Borderlands, Natural Conditions and Cultural History 1: 24 (in Mongolian).

Dashzeveg, Ts., Khishigjargal, M. 2001. Some results on the establishmend of planted larch saplings in the forest region of the eastern Khentei. Scientific Transactions of the Center of Forest Education Armona Corporation 1: 109-112 (in Mongolian). 


\section{Eidesstattliche Erklärung}

Hiermit versichere ich, die vorliegende Arbeit mit dem Titel "Response of tree-ring width and regeneration In conifer forests of mongolia to climate warming and land use"selbstständig und unter ausschließlicher Verwendung der angegebenen Literatur, Verweise und Hilfsmittel erstellt zu haben. Verwendete Quellen wurden als solche gekennzeichnet. 


\section{INDEX OF TABLES}

Table 2.1 Descriptive statistics of the tree-ring series from the interior and edge of Larix sibirica forests on Mt. Bodg Uul including the total number of sample trees $(N)$, the cambial age, the mean ring width and the expressed population signal (EPS).

Table 2.2 Definition and putative causes of studied intra-annual wood-anatomical features (after Leuschner and Schweingruber, 1996).

Table 2.3 Mean sensitivity and first-order correlation coefficients for Larix sibirica from the forest interior and forest edge. ${ }^{a}$

Table 2.4 Percentage of intra-annual wood-anatomical features of the analyzed tree-rings in old and middle-aged larch trees from the forest interior and the forest edge.

Table 2.5 Results of multiple regression analyses for explaining the stabilized frequency of intraannual wood-anatomical features in the middle-aged trees from the forest interior (FI) and the forest edge (FE) by temperature and precipitation parameters. ${ }^{\mathrm{a}}$.

Table 3.1 Age structure of the sampled Larix sibirica trees with sample size $(N)$ and mean cambial age for the individual study sites.

Table 3.2 Characterization of groups of trees differing in their annual radial stem increment (RSI) behavior within ages classes and habitats. .71

Table 3.3 Response of tree-ring width in the individual tree groups A to Y (as defined in the text) to monthly temperature and precipitation of the year of and the year prior to tree-ring formation.

Table 3.S1 Mean tree-ring width, mean sensitivity, first-order autocorrelation coefficient and expressed population signal (EPS) in the trees of A to V (as defined in the text) from the forest interior $(\mathrm{FI})$ or the forest edge (FE)

Table 3.S2 Mean tree-ring width, mean sensitivity, first-order autocorrelation coefficient and expressed population signal (EPS) in the trees of $\mathrm{A}$ to $\mathrm{V}$ (as defined in the text) from the forest interior (FI) or the forest edge (FE)

Table 3.S3 Results of four-way ANOVA analyzing the effect of the dominance type (dominant, subdominant, suppressed), the intraspecific competition class (nearest neighbor at $<1 \mathrm{~m}, 1-2 \mathrm{~m},>2$ $\mathrm{m}$ distance), tree age and the plot on mean tree-ring width in the forest interior and at the forest edge for two alternative periods (1970-2010, 1990-2010). ${ }^{\mathrm{a}}$. .83

Table 3.S4 Mean sensitivity (Sens.) and first-order autocorrelation coefficients (AC) calculated for different time intervals between 1941 and 2010 for selected groups of trees from the forest interior. ${ }^{\mathrm{a}}$. 
Table 4.1 Stand characteristics and livestock densities of the six sites in the forest interior and at

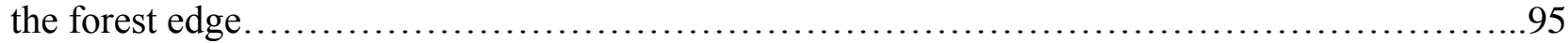

Table 4.2 Sapling numbers ( \pm SE, followed by minimum and maximum values in brackets) of different damage classes in the forest interior and at the forest edge. 100

Table 4.3 Correlation between livestock densities within 1 or $5 \mathrm{~km}$ radius from the studied $L$. sibirica stands (forest interior and edge) and the density of saplings (in trees $\mathrm{ha}^{-1}$ ) in browsing

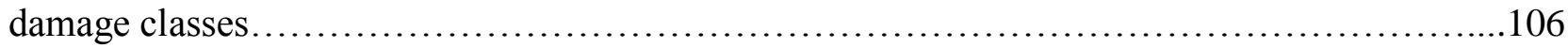




\section{INDEX OF FIGURE}

Figure 1.1. (a) Rings with extremely narrow late wood in previous years on core samples from Mt. Bogd. (b) Narrow and wedging rings on the cross-section samples from Altai Mountains during last decades.

Figure 1.2. Livestock, including sheep and goat herd, grazing in larch forest (a) and forest edge (b) of forest interior.

Figure 1.3. Location of the study region in northern Mongolia. (blue) Altai Mountains research area. (red) Bogd Mountain research area

Figure 1.4. Schematic overview of the plot design. Three research plots in forest interior and one plot in forest edge. Sample plots (20m x 20m) (gray) and sub plots (1m x 1m) (blue) for seedling counting.

Figure 1.5. Larch forest in Altai Mountains. (a) Studied forest distribution in north facing slope of Mountains. (b) forest edge and (c) forest interior. 20

Figure 2.1. Map of the study area on Mt. Bogd Uul in the southern Khentei, Mongolia. The study areas is marked with an asterisk.

Figure 2.2. Climate trends at the weather stations Ulan Bator (1360 m a.s.1.) and Zuunmod (1520 m a.s.1.). (a) Mean annual temperature in Ulan Bator (since 1940; $\mathrm{r}=0.75, P<0.001$ ) and Zuunmod (since 1965; $\mathrm{r}=0.63, P<0.001)$. (b) Mean annual precipitation $(P>0.05)$. .38

Figure 2.3. Tree-ring chronologies for Larix sibirica trees from the forest interior and the forest edge (a) Tree-ring width. (b) Tree-ring index. (c) Number of samples. FI-O, forest interior, old trees (>100 yr), FI-M, forest interior, middle-aged trees (60-100 year), FE-M, forest edge, middleaged trees (60-100 year).

Figure 2.4. Response of tree-ring width in Larix sibrica to monthly means of temperature and precipitation of the year of and the year prior to tree-ring formation. (a) Forest interior, >100-yr old

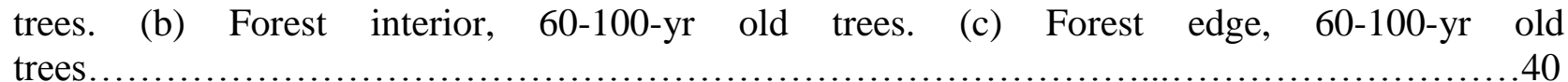
trees.

Figure 2.5. Examples of intra-annual wood-anatomical features in the wood of Larix sibirica from Mt. Bogd Uul: (a) narrow latewood, (b) light latewood, (c) frost ring, (d) density fluctuations, (e) collapsed cells, (f) dark latewood, (g) resin ducts in latewood, (h) resin ducts in earlywood.......41

Figure 2.6. Number of intra-annual wood-anatomical features in trees from the forest interior (FIO, old trees; FI-M, middle-aged trees), from the forest edge (FE-M, middle-aged trees), and all trees. Linear regression results: FI-O, $\mathrm{r}=0.61, P<0.05$; FI-M, $\mathrm{r}=0.77, P<0.01$; Total, $\mathrm{r}=0.71$, $P<0.01$

Figure 2.7. Frequency of (a-c) narrow and wide latewood, (d-f) missing rings, (g-i) dense and light latewood in (a, d, g) old trees (FI-O) and (b, e, h) middle-aged larch trees (FI-M) from the forest interior as well as (c, $\mathrm{f}, \mathrm{i})$ middle-aged trees from the forest edge (FE-M). Linear regression results: 
narrow latewood, FI-O, $\mathrm{r}=0.29, P<0.01$; FI-M, r=0.40, $P<0.01$; FE-M, $\mathrm{r}=0.36, P<0.01$; dense latewood, FI-O, r=-0.38, $P<0.01$; FI-M, r=-0.32, $P<0.01$; FE-M, r=-0.24, $P<0.01 \ldots \ldots \ldots \ldots . .44$

Supplemental Figure 2.S1. Stabilized frequency of (a-c) density fluctuations and reaction wood, (d-f) resin ducts in earlywood and latewood, (g-i) dense and light latewood in (a, d, g) old trees (FI-O) and (b, e, h) middle-aged larch trees (FI-M) from the forest interior as well as (c, f, i) middle-aged trees from the forest edge $($ FE-M) ...............................................

Figure 3.1. Trends in $(a, c)$ air temperature and (b) precipitation as well as (d) climate chart for the weather station Altai (48 $17^{\prime} \mathrm{N}, 8^{\circ} 31^{\prime} \mathrm{E}, 2150 \mathrm{~m}$ a.s.1.), western Mongolia from 1940 to 2010 (71 years). (a) Annual mean temperature. (b) Annual precipitation. (c) Trends of monthly mean temperatures (only regression lines are plotted). Calculated values $(\mathrm{a}, \mathrm{b})$ are based on linear regression across all months with data from the weather station Ulgii City. .64

Figure 3.2. Tree-ring chronologies for the very old trees (cambial age $>160$ years) from the interior (groups A, B) and the edge (groups C, D) of the forest including different growth trends in the forest interior during the past 100 years and at the forest edge during the past 130 years. (a) Tree-ring width. (b) Tree-ring index. (c) Number of samples.

Figure 3.3. NMDS ordination of tree-ring series from different age classes in the forest interior or the forest edge. (a) Very old trees (>160 years) from the forest edge. (b) Old trees (101-160 years) from the forest interior. (c, d) Middle-age trees (60-100 years) from the (c) forest interior or (d) the forest edge. $(e, f)$ Young trees $(<60$ years) from the (e) forest interior or $(f)$ the forest edge........70

Figure 3.4. Tree-ring chronology for old trees (cambial age 101-160 years) from the forest interior with three groups of trees (G, E and F) with different growth characteristics. (a) Tree-ring width. (b) Number of samples.

Figure 3.5. Tree-ring chronology for middle-aged trees (cambial age 60-100 years) from the forest interior with four groups of trees (H, I, J and K) with different growth characteristics. (a) Tree-ring width. (b) Number of samples.

Figure 3.6. Tree-ring width in middle-aged trees at site 1 showing a sudden increase in the annual stem increment in 1995 at the forest edge (group $\mathrm{N}$ trees) and time delayed in 1997 in the forest

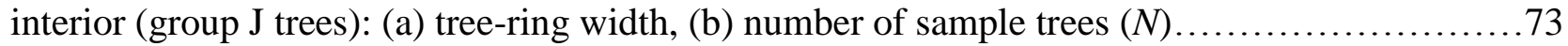

Figure 3.7. Influence of tree age on first-order autocorrelation, mean sensitivity and the beta value for the correlation of the June temperature of the previous year with tree-ring width in $>60$-year old larch trees. Dots represent weighted arithmetic means.

Figure 3.8. Cumulative regional growth curve (a) with number of samples (b) for the largest groups of old (group E), middle-aged (group H) and young (group Q) trees from the forest interior of sites 1 to 6 . The slopes of linear regression lines calculated for the individual tree-ring series differ significantly (ANCOVA, $P<0.001, F=381, \mathrm{df}=2,155$ ). Filled dots mark inflection points..................................................................... 77

Figure 3.9. Total numbers of tree stumps per hectare (a) and ratio of stumps to live trees (b) in the forest interior and the forest edge. Asterisk indicates significant difference (U-test, $P \leq 0.05) \ldots \ldots .78$ 
Figure 3.10. Cumulative distribution plot of heavy ( $a$ and $c$ ) and moderate ( $b$ and $d$ ) selective logging in the six study sites in the forest interior ( $a$ and $b$ ) and the forest edge (c and $d$ ). Note that the analysis for the forest edge only covered the period from 1963 to 2010 because the tree age distribution differed from the forest interior.

Figure 4.1. Location of the study area in the Mongolian Altai in westernmost Mongolia. Black areas represent the distribution of $L$. sibirica forests (distribution in Russia where L. sibirica occurs everywhere within the map section is not shown). Gray areas are lakes.

Figure 4.2. Years of establishment of the present L. sibirica populations (a) in the forest interior and (b) at the forest edge, including live and dead mature trees (DBH $>3 \mathrm{~cm}$ ) and sapling-sized trees $(\mathrm{DBH} \leq 3 \mathrm{~cm})$.

Figure 4.3. Examples of wood-anatomical anomalies in stem cross-sections of L. sibirica saplingsized trees: (a) unclosed injury due to browsing, (b) enlarged section of (a), (c) narrow and

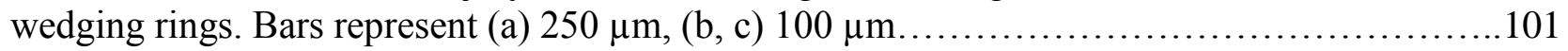

Figure 4.4. Frequency of $(a, b)$ wedging rings and $(c, d)$ reaction wood in sapling-sized trees from the $(a, c)$ interior and $(b, d)$ edge of larch forests. Percentages refer to the number of sapling-sized trees available in the relevant year.

Figure 4.5. Distribution of (a) live and (b) dead sapling-sized trees in different tree height classes in the forest interior and at the forest edge. .103

Figure 4.6. Relative frequency of damage classes in sapling-sized trees of different height classes (a) in the forest interior and (b) at the forest edge. 103

Figure 4.7 Densities of sapling-sized trees in the forest interior and at the forest edge as a function of livestock density: (a) total of live saplings and total livestock within $1 \mathrm{~km}$ radius, (b) total of live saplings and goats within $1 \mathrm{~km}$ radius, (c) undamaged saplings ( $0 \%$ defoliation) and total livestock within $5 \mathrm{~km}$ radius, (d) saplings with 26-50\% defoliation and total livestock within $1 \mathrm{~km}$ radius, (e) saplings with 76-99\% defoliation and total livestock within $1 \mathrm{~km}$ radius, (f) dead saplings and total livestock within $1 \mathrm{~km}$ radius. Linear regression for forest-interior data and nonlinear regression (exponential decline) for forest-edge data; for $r$ and $P$ values.. 105

Figure 4.8. Densities of (a) 1-yr old and (b) 2-yr old L. sibirica seedlings in the forest interior and at the forest edge as a function of total livestock density within $1 \mathrm{~km}$ radius. In contrast to the interior, significant linear correlations occur at the edge: (a) $r=0.76, P=0.04$, (b) $r=0.84$,

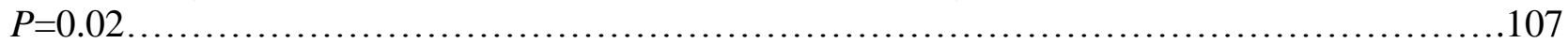

